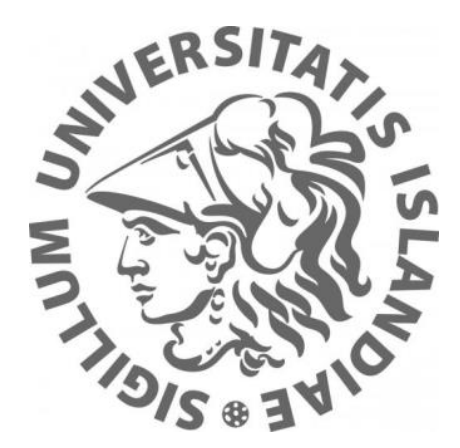

\title{
Direct Membrane Filtration of Municipal Wastewater: Linking Periodical Physical Cleaning with Fouling Mechanisms
}

Selina Hube

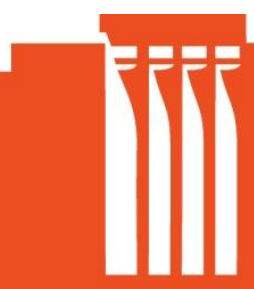

Faculty of Environmental and Civil Engineering

University of Iceland

2020 



\title{
Direct Membrane Filtration of Municipal Wastewater: Linking Periodical Physical Cleaning with Fouling Mechanisms
}

\author{
Selina Hube \\ 60 ECTS thesis submitted in partial fulfillment of a \\ Magister Scientiarum degree in Environmental Engineering \\ MS Committee \\ Bing Wu (University of Iceland) \\ Hrund Ólöf Andradóttir (University of Iceland) \\ Tzyy Haur Chong (Nanyang Technological University) \\ Master's Examiner \\ Ragnhildur Gunnarsdóttir (EFLA)
}

Faculty of Civil and Environmental Engineering

School of Engineering and Natural Sciences

University of Iceland

Reykjavik, May 2020 
Direct Membrane Filtration of Municipal Wastewater: Linking Periodical Physical Cleaning with Fouling Mechanisms

Optimization of DMF for an Icelandic Scenario

60 ECTS thesis submitted in partial fulfillment of a Magister Scientiarum degree in Environmental Engineering

Copyright (C) 2020 Selina Hube

All rights reserved

Faculty of Civil and Environmental Engineering

School of Engineering and Natural Sciences

University of Iceland

Tæknigarður - Dunhagi 5

107 Reykjavík

Iceland

Telephone: 5254000

Bibliographic information:

Selina Hube, 2020, Direct Membrane Filtration of Municipal Wastewater: Linking Periodical Physical Cleaning with Fouling Mechanisms, Master's thesis, Faculty of Civil and Environmental Engineering, University of Iceland, pp. 73.

Printing: Hàskòlaprent

Reykjavik, Iceland, May 2020 



\section{Abstract}

Direct membrane filtration (DMF) of municipal wastewater offers an alternative solution for centralized and decentralized wastewater treatment in Iceland. The efficiency of biologicalbased wastewater treatment is restricted in Iceland, due to low temperatures and high wastewater inflow rates with extremely low concentration of organics. This study aims to investigate membrane fouling mechanisms and mitigation approaches during DMF of municipal wastewater. The DMF experiments were performed using a crossflow flat sheet membrane filtration cell integrated with an optical coherence tomography (OCT) imaging system. The effects of membrane material, operation conditions and cleaning protocol on DMF performance and foulant composition were examined. The threshold flux testing results indicated that a PVDF membrane $(0.08 \mu \mathrm{m})$ was suitable for DMF of wastewater. Increasing crossflow velocity, physical flushing frequency and flushing water temperature contributed greatly to mitigate fouling. During a continuous DMF process, reversible fouling was predominant, while during intermittent DMF with periodical physical cleaning, irreversible/ irremovable fouling was dominant. A possible shift of tightly attached cake layer to irreversible/ irremovable fouling was revealed by the direct observation of fouling via OCT. The foulants autopsy indicated that a combination of organic and inorganic foulants was attributed to membrane fouling, instead of biological fouling. Under the optimized filtration condition, sustainable long-term DMF operation ( $230 \mathrm{~h})$ was achieved by employing a combination of periodical physical flushing with chemical-enhanced flushing. The water quality analysis showed that the DMF process could efficiently remove solids and greater-sized soluble organics, allowing the treated water to meet wastewater discharge standards. 


\section{Útdráttur}

Bein himnusíun (DMF) á heimilisskólpi er mögulegur valkostur fyrir miðlæga og dreifða skólphreinsun á Íslandi par sem skilvirkni líffræðilegrar skólphreinsiaðferða líður fyrir lágt hitastig og hátt rennsli skólps með lágum styrkleika lífrænna efna. Rannsóknin miðar að pví að kanna örveruvöxtur á himnur og aðferðir við DMF heimilisskólps. DMF-tilraunir voru framkvæmdar með pví að nota krossflæði flatar himnusíunarfrumu sampætt við sjónkerfisljósmyndatökukerfi (OCT). Áhrif himnunnar, rekstrarskilyrða og hreinsunarferlis á frammistöðu DMF og samsetningu fyrirstöðunnar voru skoðuð. Prófanir á viðmiðunarrennslismörkum bentu til pess að PVDF himna $(0,08 \mu \mathrm{m})$ væri hentugt fyrir DMF skólp. Hækkun hraða pvert á rennsli, vélrænnar skolunartíðni og hitastigs skolaðs vatns stuðlaði stórlega að pví að draga úr himnufóðringu. Meðan á stöðugu DMF-ferli stóð var jafngeng fyrirstaða ríkjandi en á meðan DMF gekk í lotum með reglubundinni hreinsun var óafturkræf / óhreyfanleg mengun ríkjandi. Hugsanleg breyting á péttu áföstu lögunum yfir í óafturkræfa / óhreyfanlega mengun kom í ljós með beinni athugun á himnufóðrun í gegnum OCT. Krufning fyrirstaðanna benti til pess að sambland af lífrænum og ólífrænum fyrirstöðum væri rakin til himnufúðar, í stað líffræðilegrar fyrirstöðu. Undir hámörkuðu síunarástandi var sjálfbærri langtíma DMF-aðgerð ( 230 klst.) náo með pví að nota blöndu af reglubundinni vélrænni skolun og efnafræðilegri skolun. Greining á vatnsgæðum sýna í inn- og útrennsli sýndi að DMF-ferlið gæti með skilvirkum hætti fjarlægt föst efni og stærri uppleysanleg og lífræn efni, svo að meðhöndlað vatn uppfylli staðla losun frárennslisvatns. 



\section{Table of Contents}

List of Figures ...........................................................................................................................

List of Tables.............................................................................................................xiii

Abbreviations ................................................................................................................................ xiv

Acknowledgements ........................................................................................................................... xvii

1 Introduction........................................................................................................................ 1

1.1. Importance and Status of Wastewater Treatment.................................................. 1

1.1 Secondary Wastewater Treatment Technologies ..................................................... 3

1.1.1 Conventional Activated Sludge Method ........................................................ 3

1.1.2 Membrane Bioreactor (MBR) .................................................................... 4

1.1.3 Direct Membrane Filtration (DMF) ………………………………….... 5

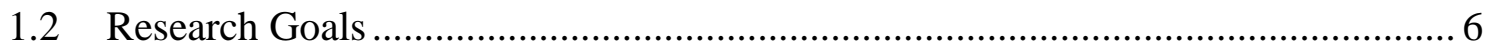

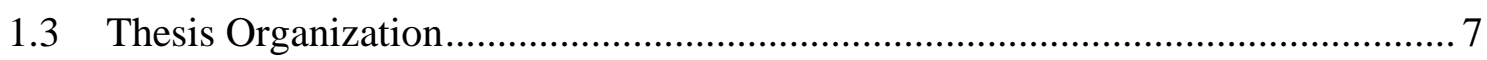

2 Technological Background..........................................................................................9

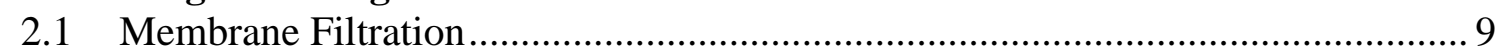

2.2 Membrane Fouling .......................................................................................... 10

2.3 Treatment Performance of DMF .................................................................... 12

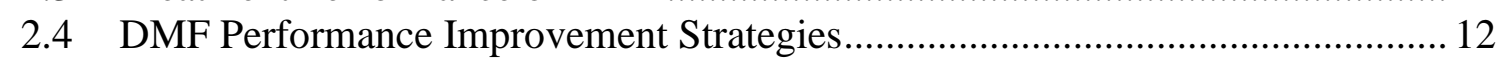

2.5 Frontiers of Research and Gaps in Knowledge of DMF ....................................... 14

3 Materials and Methods........................................................................................... 17

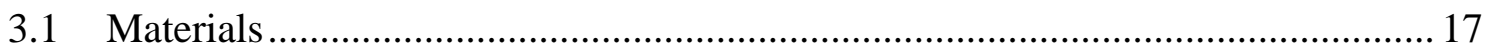

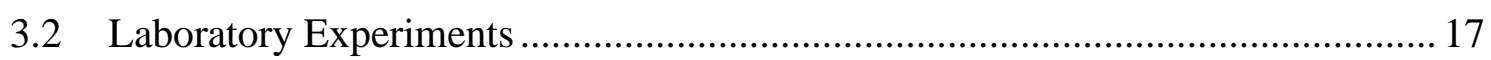

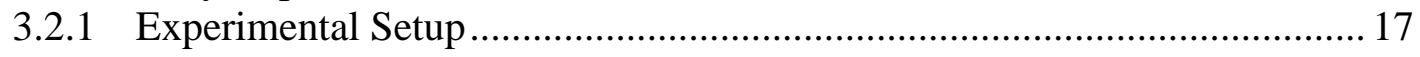

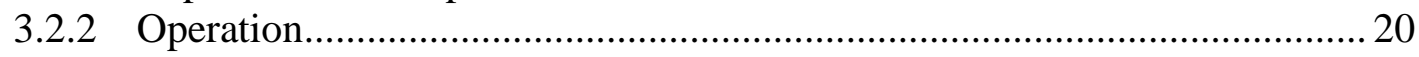

3.3 Threshold Flux Determination ....................................................................... 20

3.4 Membrane Resistance Analysis...................................................................... 21

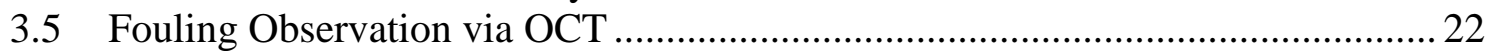

3.6 Analysis of Water Quality and Foulants Characteristics ...................................... 23

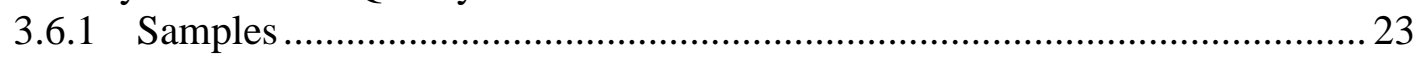

3.6.2 Feed and Permeate Strength (COD, TSS, TOC)........................................... 23

3.6.3 Liquid Chromatography - Organic Carbon Detection (LC-OCD) ............... 23

3.6.4 Inductively Coupled Plasma - Optical Emission Spectroscopy (ICP-

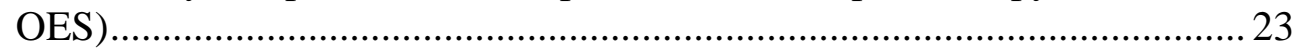

3.6.5 Fluorescence Spectrophotometer ............................................................. 23

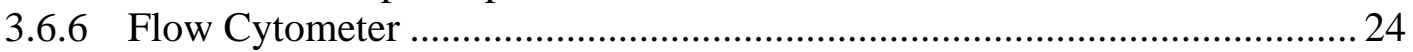

3.6.7 Adenosin Triphosphate (ATP) …………………………………….... 24

3.6.8 Ion Chromatography (IC) .................................................................. 24

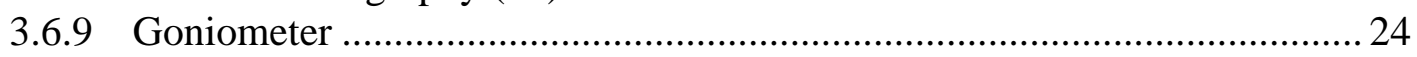

3.6.10 Fourier-Transform Infrared Spectroscopy (FTIR) ……………………...... 24 
3.6.11 Scanning Electron Microscopy (SEM) ................................................ 24

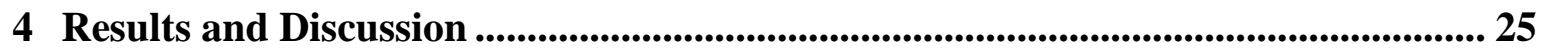

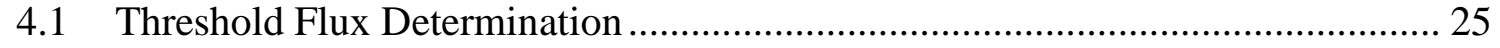

4.2 Effect of Operation Conditions on DMF Performance ....................................... 28

4.2.1 Feed Pressure under Continuous and Intermittent Filtration....................... 28

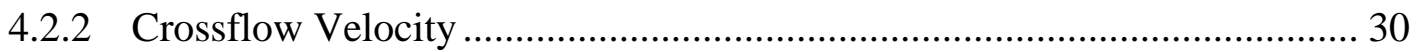

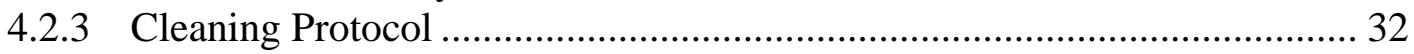

4.2.4 Direct Observation of Fouling via OCT …............................................ 40

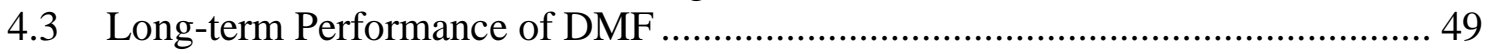

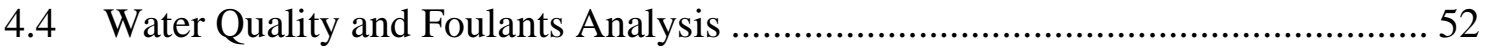

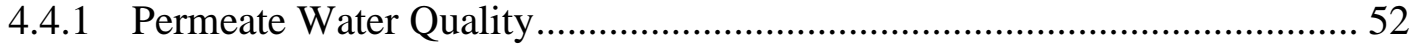

4.4.2 Membrane Foulants Analysis ............................................................... 54

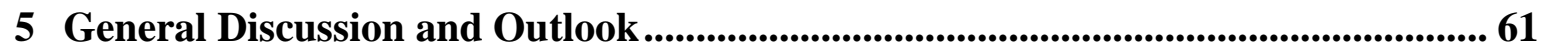

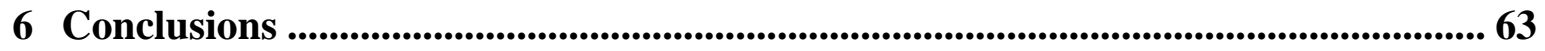

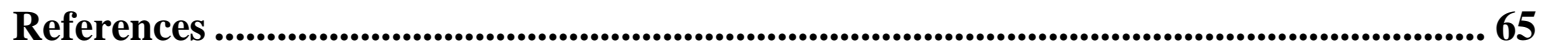

Appendix ................................................................................................................................... 71 


\section{List of Figures}

Figure 1. Changes in urban wastewater treatment in northern European countries (European Environment Agency, 2017).

Figure 2. Wastewater treatment shown as percentage of the population with secondary treatment, primary treatment and septic tank with infiltration system both in rural and urban areas (Umhverfisstofnun, 2013)....

Figure 3. Wastewater treatment methods in different regions in Iceland in percentage for agglomerations $>500$ inhabitants (Umhverfisstofnun, 2013). 3

Figure 4. Conventional wastewater treatment process with activated sludge treatment.

Figure 5. Advanced wastewater treatment: a) MBR process, b) submerged MBR.

Figure 6. A schematic diagram of dead-end (a) and crossflow (b) filtration (Crittenden et al., 2012).

Figure 7. Fouling mechanisms: (a) Pore blocking, (b) pore constriction and (c) cake layer formation (Crittenden et al., 2012)

Figure 8. Batch-scale DMF setup

Figure 9. Filtration cell used in DMF setup

Figure 10. Batch-scale DMF setup with an auto-controlled cleaning system.

Figure 11. Basic principle of Fourier-domain OCT of fouling process in a membrane filtration cell (Sim and Fane, 2017).

Figure 12. The dTMP/dt profiles for threshold flux determination (at a feed pressure of $50 \mathrm{kPa})$

Figure 13. The dTMP/dt profiles for threshold flux determination (at a feed pressure of $8 \mathrm{kPa}$ ).

Figure 14. TMP evolution of PVDF (a) and RC membranes (b) at different feed pressures with clean water flushing and chemical cleaning after filtration...... 28

Figure 15. Filtration resistances at different feed pressures

Figure 16. Membrane fouling rate (dTMP/dt) during intermittent filtration with wastewater flushing at different flow rates.

Figure 17. Cake layer (a) and irreversible and irremovable (b) fouling resistances at various flow velocities during intermittent filtration with wastewater flushing $\left(25^{\circ} \mathrm{C}, 0.1 \mathrm{~m} / \mathrm{s}\right)$. 
Figure 18. Membrane fouling rate (dTMP/dt) at varying temperatures during intermittent filtration with tap water flushing $(0.1 \mathrm{~m} / \mathrm{s})$

Figure 19. Membrane fouling rate (dTMP/dt) at varying filtration and flushing flow velocities $\left(50{ }^{\circ} \mathrm{C}\right.$ tap water)

Figure 20. Cake layer (a) and irreversible and irremovable (b) resistance at varying temperatures during intermittent filtration with tap water flushing $(0.1$ $\mathrm{m} / \mathrm{s})$.

Figure 21. Cake layer (a) and irreversible and irremovable (b) fouling resistances at $1.25 \mathrm{~h}$ filtration interval and varying filtration and flushing flow velocities (rates with $50{ }^{\circ} \mathrm{C}$ tap water).

Figure 22. Membrane fouling rate (dTMP/dt) during intermittent filtration with heated tap water flushing 38

Figure 23. Resistances during intermittent filtration with heated tap water 40

Figure 24. OCT images of the cake layer evolution - PVDF (left) and RC (right) at 8 $\mathrm{kPa}$ feed pressure, $0.1 \mathrm{~m} / \mathrm{s}$ filtration, clean water flushing and chemical cleaning with $0.5 \% \mathrm{NaOCl}$

Figure 25. OCT images of the cake layer evolution - PVDF (left) and RC (right) at 50 $\mathrm{kPa}$ feed pressure, $0.1 \mathrm{~m} / \mathrm{s}$ filtration, clean water flushing and chemical cleaning with $0.5 \% \mathrm{NaOCl}$

Figure 26. Cake layer thickness during filtration with RC (a) and PVDF (b) membrane

Figure 27. Cake layer evolution during clean water at varying flow velocities flushing of the PVDF membrane after filtration at $50 \mathrm{kPa}$ feed pressure and $0.1 \mathrm{~m} / \mathrm{s}$ flow velocity.

Figure 28. TMP curve during intermittent long-term filtration with heated tap water flushing and chemical cleanings (red lines)

Figure 29. dTMP/dt during long-term intermittent filtration with heated tap water flushing and chemical cleanings (red lines)

Figure 30. SEM images of the cake layer foulants after filtration at different conditions (×3000 magnification; 1,25 h-filtration with 10 min flushing)

Figure 31. FTIR profiles of virgin and fouled membranes 59 


\section{List of Tables}

Table 1. The flat sheet membranes used in this study ................................................... 17

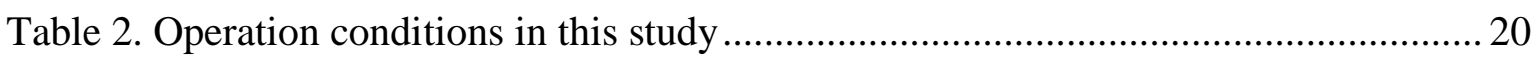

Table 3. A summary of threshold fluxes of the tested membranes ................................... 27

Table 4. Membrane fouling rate (dTMP/dt) and membrane resistance during intermittent filtration with wastewater flushing at different feed pressures

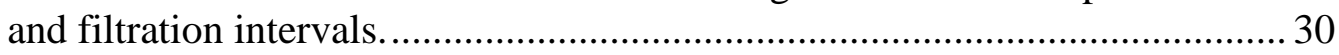

Table 5. Membrane fouling rate (dTMP/dt) and resistance values during intermittent filtration with heated tap water flushing .................................................... 39

Table 6. Averaged cake layer thickness data for different operation conditions during

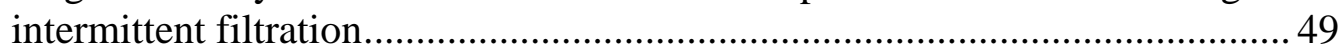

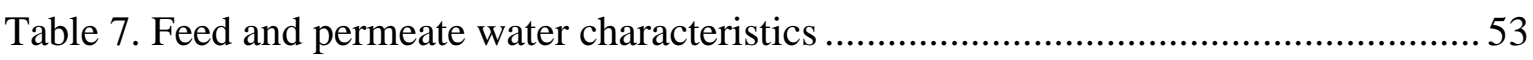

Table 8. Analysis of soluble foulant and microbial foulant characteristics........................ 57

Table 9. Contact angles of the clean and fouled membranes ...........................................58 


\section{Abbreviations}

A

ATP

$\mathrm{BOD}_{5}$

C

CDOC

CEB

CV

DMF

DOC

DON

$\mathrm{dTMP} / \mathrm{dt}$

EEM

Em

Ex

F

FP

FIT

FTIR

$\mathrm{HOC}$

HP

IC

ICP-OES

J

LC-OCD

LMH
Area

Adenosine triphosphate

Biochemical Oxygen demand

Computer

Hydrophilic organic Carbon

Chemical enhanced backwash

Check valve

Direct membrane filtration

Dissolved organic Carbon

Dissolved organic Nitrogen

TMP increase over time

Excitation emission matrix

Emission

Excitation

Feed tank

Feed pump

Flushing tank

Fourier-transform infrared spectroscopy

Hydrophobic organic Carbon

Heating plate

Ion chromatography

Inductively coupled plasma - optical emission spectroscopy

Flux

Liquid chromatography - organic Carbon detection

$\mathrm{L} / \mathrm{m}^{2} \mathrm{~h}$ 


\begin{tabular}{|c|c|}
\hline LMW & Low molecular weight \\
\hline$\mu$ & Viscosity of water \\
\hline MBR & Membrane bioreactor \\
\hline MF & Microfiltration \\
\hline MM & Membrane module \\
\hline MW & Molecular weight \\
\hline NA & Non applicable \\
\hline ND & Not determined \\
\hline NEWRI & Nanyang environment and research institute \\
\hline NF & Nanofiltration \\
\hline OCT & Optical coherence tomography \\
\hline $\mathrm{P}$ & Permeate tank \\
\hline $\mathrm{P} 1 / 2$ & Pressure gauge \\
\hline PES & Polyethersulfone \\
\hline PP & Permeate pump \\
\hline PV & Pressure valve \\
\hline PVDF & Polyvinylidene fluoride \\
\hline $\mathrm{Q}$ & Flow rate \\
\hline $\mathrm{RC}$ & Regenerated cellulose \\
\hline $\mathrm{R}_{\mathrm{c}}$ & Cake layer resistance \\
\hline $\mathrm{R}_{\text {ir }}$ & Irreversible resistance \\
\hline $\mathrm{R}_{\mathrm{im}}$ & Irremovable resistance \\
\hline $\mathrm{R}_{\mathrm{m}}$ & Membrane resistance \\
\hline RO & Reverse osmosis \\
\hline S & Scale \\
\hline SAC & Spectral absorption \\
\hline SEM & Scanning electron microscope \\
\hline
\end{tabular}


SMTC Singapore membrane technology center

SS Suspended solids

ST

Stirrer

SUVA Specific UV absorbance

SV

Solenoid valve

TMP

Trans-membrane pressure

TN

Total Nitrogen

TOC

Total organic Carbon

$\mathrm{TP}$

Total Phosphorus

TSS

Total suspended solids 


\section{Acknowledgements}

First, I would like to thank A/Prof. Bing Wu for trusting me and making this project possible, for her mentorship, guidance, encouragement and sharing her knowledge with me. I would also like to thank Prof. Hrund Ólöf Andradóttir for her help as a member of the MS committee and Ragnhildur Gunnarsdóttir for her review of the thesis.

I would like to thank the Singapore Membrane Technology Center (SMTC) for welcoming me, providing and introducing me to the equipment, their guidance and always being there for my questions. My sincere thanks go to A/Prof. Chong Tzzy Haur, Dr. Jingwei Wang and Dr. Lee Nuang Sim and the Analytics team of Nanyang Environment and Research Institute (NEWRI).

I am thanking the University of Iceland Research Fund for sponsoring this project.

Last, I would like to express my profound gratitude to my family for their immense support and encouragement. 



\section{Introduction}

\subsection{Importance and Status of Wastewater Treatment}

The release of untreated wastewater to the natural environment leads to potential risks, such as eutrophication, occurrence of micropollutants and microplastics or waterborne pathogens. Therefore, wastewater treatment is not only extremely important for the quality of our environment, but also for maintaining public health (European Environment Agency, 2017). Especially, the release of micropollutants (pharmaceuticals, endocrine disruptors, pesticides, heavy metals and viruses/pathogens) is expected to be strictly regulated in order to protect the environment and the inhabitant's health (Hey et al., 2018).

Recent studies have shown that in high-income countries about $70 \%$ of the wastewater is treated, while it is only $38 \%$ and $28 \%$ in upper- and lower-middle-income countries respectively and $8 \%$ in low-income countries (Sato et al., 2013). More, while the European discharge standards are met in over $80 \%$ of the cases in the European Union, only below $20 \%$ of effluents in other parts of the world meet the discharge standards (World Health Organization and United Nations, 2018). The United Nations Sustainable Development Goal number 6 aims to improve water quality and protect water related ecosystems globally. The target is to halve the proportion of untreated wastewater before 2030 (United Nations, 2015).

Wastewater treatment in Iceland is not very developed and direct discharge is still common. Compared to other countries in northern Europe, Iceland has a very low percentage of treated wastewater. Of particular notice is the very low ratio of wastewater that undergoes secondary (biological) or tertiary treatment for nutrient removal (Figure 1) (European Environment Agency, 2017).
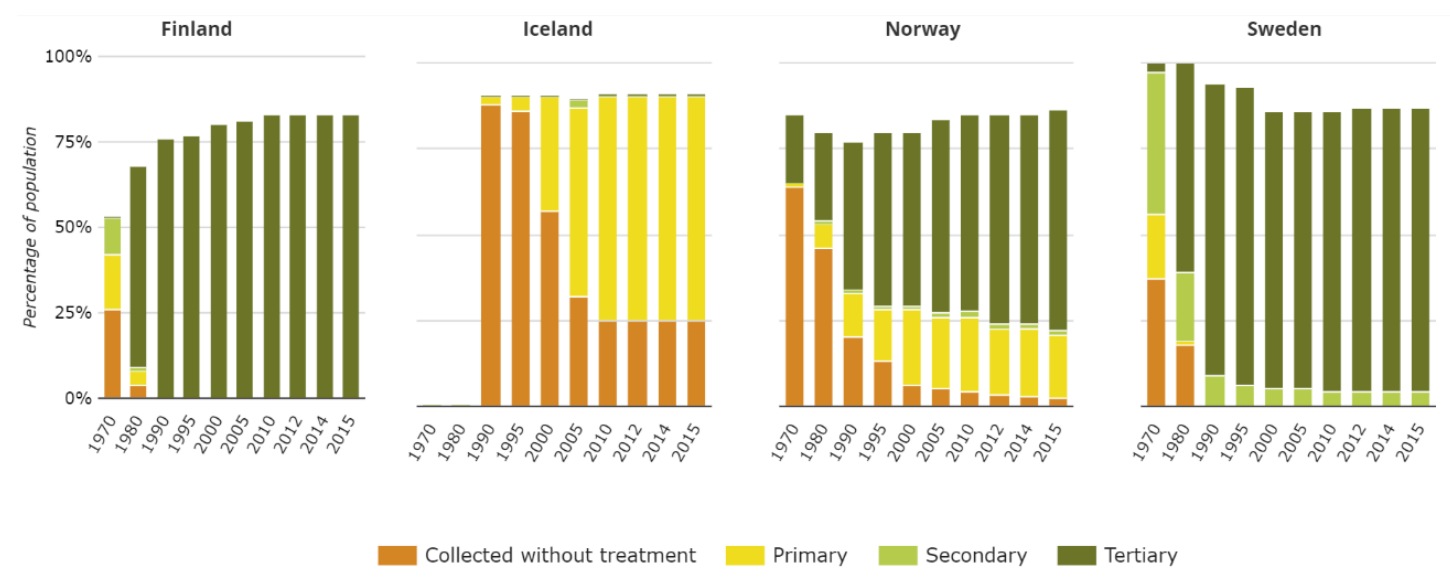

Figure 1. Changes in urban wastewater treatment in northern European countries (European Environment Agency, 2017). 
In Reykjavík, the capital and largest municipality in the country, wastewater only undergoes primary treatment, which aims to remove coarse material, sand and fat. According to the Icelandic regulation on wastewater systems nr. 798/1999 (Reglugerð um fráveitur og skólp nr. 798/1999), primary treatment requires minimum $50 \%$ removal of Total Suspended Solids (TSS) and at least $20 \%$ removal of Biochemical Oxygen Demand (BOD5). The treated wastewater is discharged into the sea $(\sim 4$ to $5 \mathrm{~km}$ away from the coastal area). Primary treatment can only remove $\sim 10$ (screen) to $50 \%$ (settling basin) of suspended solids (mainly greater than $1 \mathrm{~mm}$ ) and $\sim 10$ (screen) to $20 \%$ (settling basin) of the $\mathrm{BOD}_{5}$ (Sævarsson, 2018). Although the discharged wastewater effluent does not or only slightly influence the water quality in the sea (Veitur, 2019), the treated wastewater quality cannot meet the EU discharge standards. In other large municipalities (Akureyri, Selfoss, Egilsstadir), very limited wastewater treatment facilities are available (EFLA Engineering, 2019; Iceland Review, 2017). In small communities, the wastewater is generally treated by septic tanks or directly discharged into the ocean or large water bodies (Figure 2 and Figure 3 ). This practice can increase the risk of waterborne outbreaks in rural areas, and harm the country's tourism industry that has grown steadily in the past decade
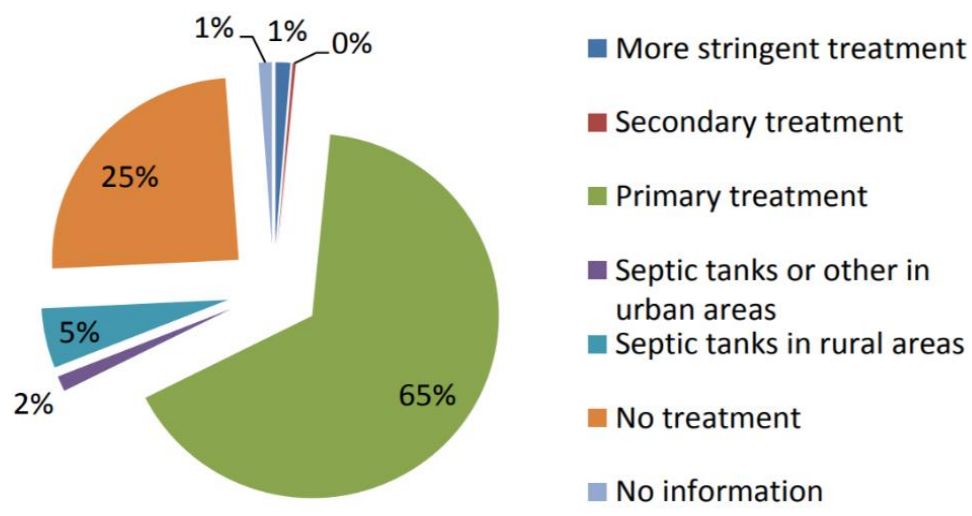

Figure 2. Wastewater treatment shown as percentage of the population with secondary treatment, primary treatment and septic tank with infiltration system both in rural and urban areas (Umhverfisstofnun, 2013). 


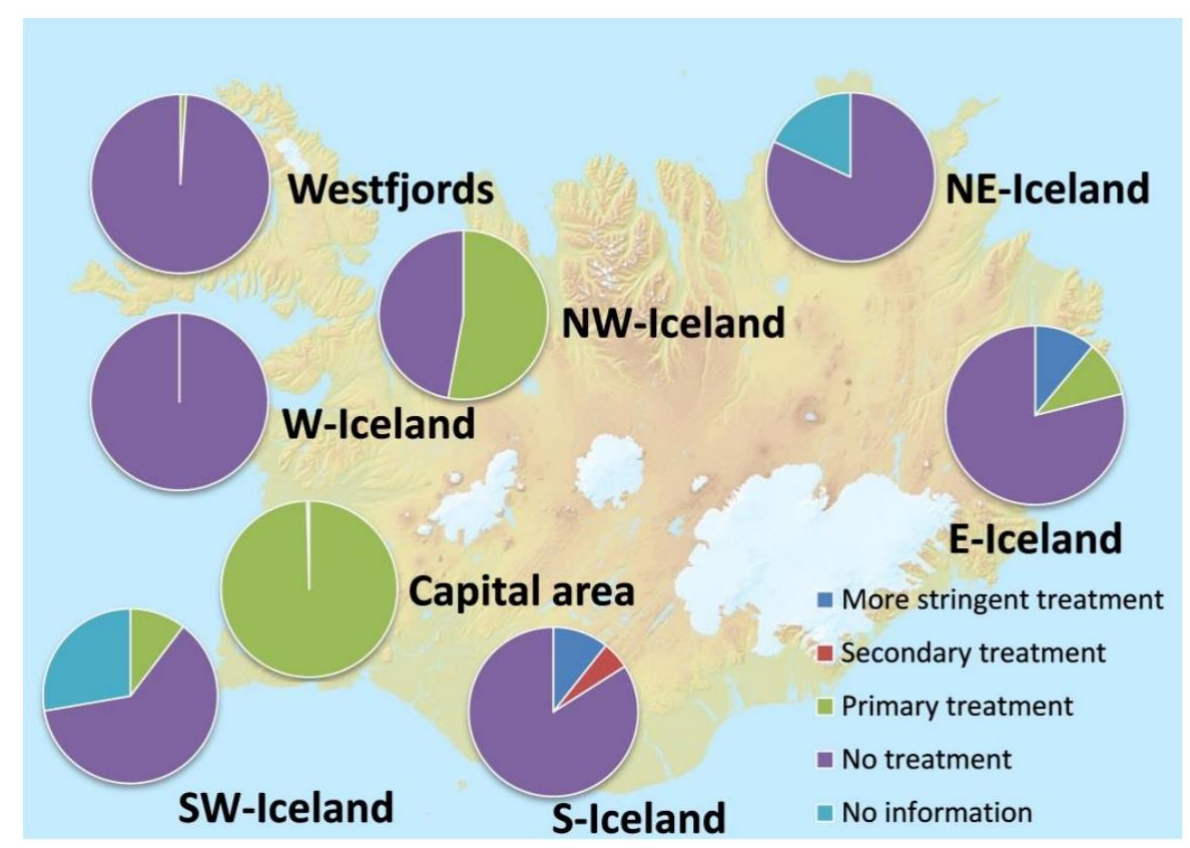

Figure 3. Wastewater treatment methods in different regions in Iceland in percentage for agglomerations >500 inhabitants (Umhverfisstofnun, 2013).

\subsection{Secondary Wastewater Treatment Technologies}

\subsubsection{Conventional Activated Sludge Method}

A conventional wastewater treatment process usually combines a primary and a secondary process (Figure 4). In detail, a bar screen removes large objects, followed by a grit chamber that facilitates the settling of higher-density solids (sand and stones). After that, a settling process further removes particulate organics and inorganics (collected as waste sludge). In the following activated sludge process, microorganisms degrade organics/ inorganics and produce new cells. The activated sludge is separated from the flow in a secondary settling tank, one part of which is recirculated back to the aeration tank and another part is collected as waste sludge. Additionally, most treatment plants have a tertiary treatment step, which serves as disinfection or nutrient removal before releasing the water into a receiving water body (Tchobanoglous et al., 2003).

This process shows satisfying treatment efficiencies. However, the high energy consumption of aeration in the activated sludge system leads to an increase in operation costs. The mean energy consumption of a conventional wastewater treatment plant ranges between 0.1$1.89 \mathrm{kWh} / \mathrm{m}^{3}$ (Hey et al., 2018; Kimura et al., 2017; L. Luo et al., 2019; Mizuta and Shimada, 2010; Plappally and Lienhard V, 2012; Wan et al., 2016; Zhang et al., 2016). Biological treatment in general is not always practicable as it demands a constant feed water flow and stable climatic conditions in preferably warm temperatures $\left(20\right.$ to $\left.25^{\circ} \mathrm{C}\right)$. The biological treatment needs long start-up periods to adapt to a new or changed feed. Therefore, extreme climatic conditions, a discontinuous water flow or small wastewater quantities can lead to cost and management issues (Hedaoo et al., 2012; Ravazzini et al., 2005). 


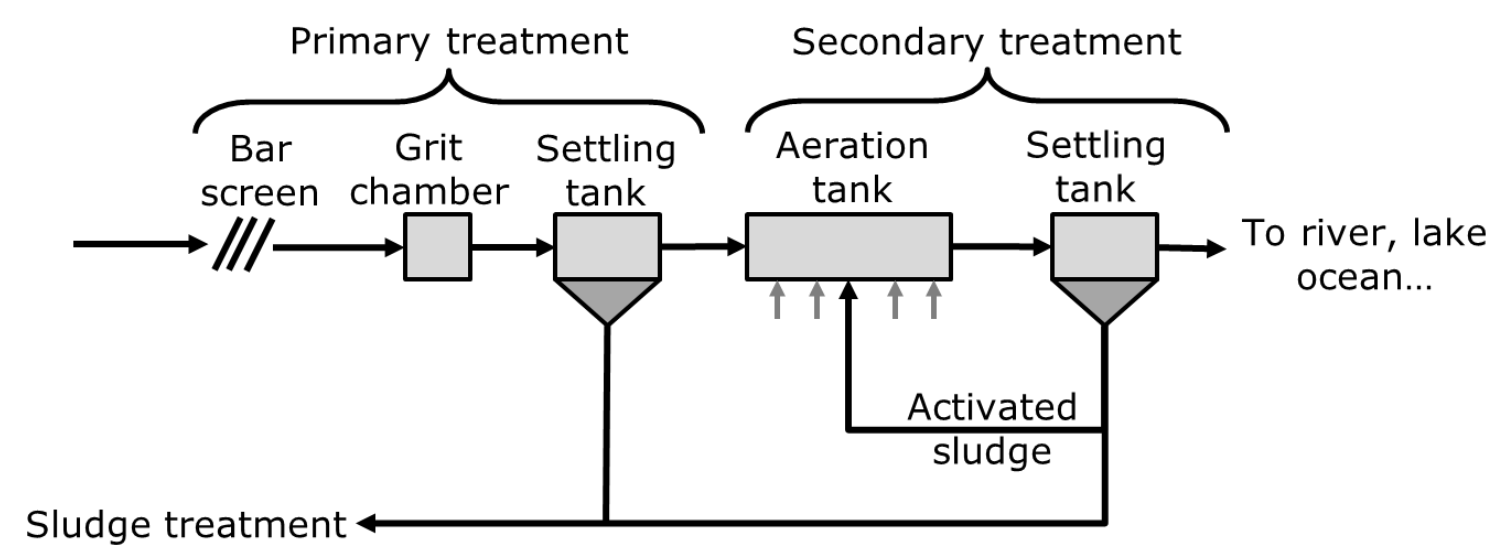

Figure 4. Conventional wastewater treatment process with activated sludge treatment.

\subsubsection{Membrane Bioreactor (MBR)}

Alternatively, a MBR has been widely used as a secondary treatment process for wastewater treatment. A MBR combines an activated sludge process and a membrane separation process in one tank (Figure 5). The sludge performs the role in degrading organics/inorganics and the porous membrane (microfiltration (MF) or ultrafiltration (UF)) is employed to reject the sludge and allows treated water passing through. It has thus a lower footprint than the conventional biological treatment, produces a higher permeate quality and less waste sludge (Hoinkis et al., 2012; Wu and Fane, 2012). A detailed introduction on membrane filtration process will be given in the Section 2.1 and 2.2.

The main issue in MBR technology is severe membrane fouling, as microbial biofilms, organic matter, colloids and inorganic components from the feed accumulate on the membrane, causing a flux decrease (Straub et al., 2020). Especially soluble microbial products and extracellular polymeric substances from the activated sludge cause heavy fouling (Sano et al., 2020). The process is thus highly dependent on the feed composition. The high fouling rate demands for efficient cleaning protocols. In the last decade, the fouling control strategies for MBR have been improved and made MBR more cost efficient. The most commonly used is intensive aeration of the membrane, which removes foulants by shear. Fouling can also be controlled by optimized operation conditions and setup design, novel membrane materials, backwashing, chemical cleaning or pre-treatment. However, Aeration increases the operation costs significantly, as it consumes $\sim 70 \%$ of total required energy. Moreover, chemical cleaning creates secondary pollutants. Both strong shear and chemical cleaning limit membrane lifespan and integrity, which causes additional cost increase. Overall, MBR operation costs are higher than that of the conventional activated sludge process (Mishima and Nakajima, 2009; Ng et al., 2013; Wu and Fane, 2012; L. Wu et al., 2018). 


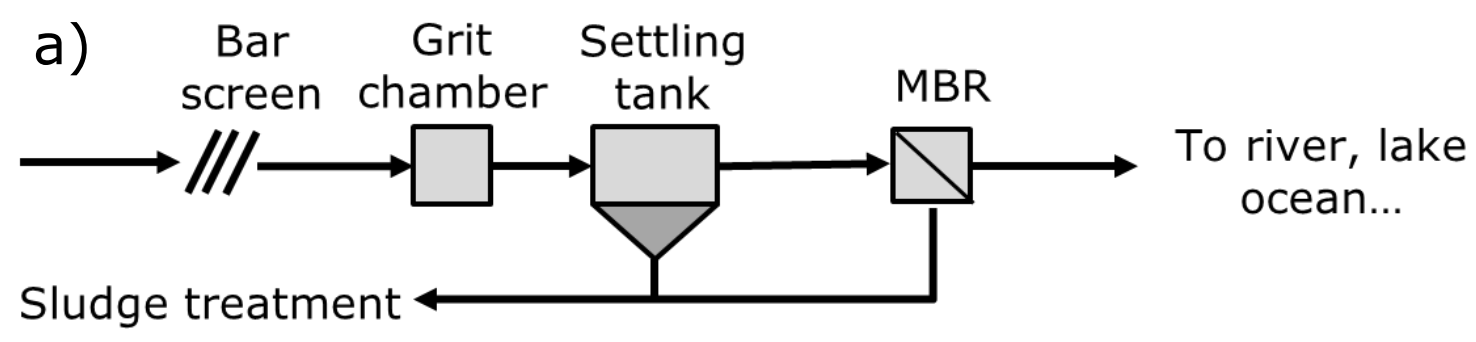

b)

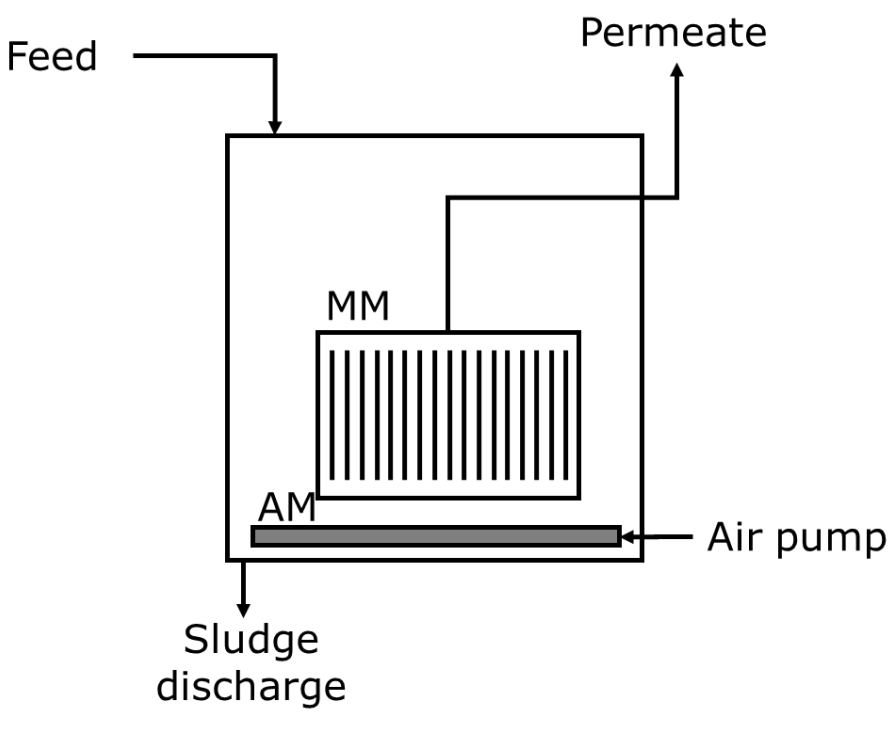

$\begin{array}{lll}M M & = & \text { Membrane module } \\ \mathrm{AM} & =\text { Aeration module }\end{array}$

Figure 5. Advanced wastewater treatment: a) MBR process, b) submerged MBR

\subsubsection{Direct Membrane Filtration (DMF)}

Recently, DMF has received great attention, providing an alternative promising solution for secondary wastewater treatment. In DMF, the wastewater is directly filtered by a porous membrane, without a prior biological step and thus it is a completely physical process (Hey et al., 2017; Mezohegyi et al., 2012; Ravazzini et al., 2005). DMF can serve two purposes in a wastewater treatment process: (1) the membrane filtration is employed to produce high quality permeate water, and (2) DMF can be used as a pre-concentration step for organic matter and thus energy recovery (Hey et al., 2017; Ravazzini et al., 2005). The key operational constraint of DMF is membrane fouling, which refers to the deposition of feed components on or inside the membrane. Compared to a conventional biological treatment process and MBR, DMF has several advantages. (1) DMF has a relatively simple system configuration, requiring less capital cost and footprint (as no biological tank is needed). (2) 
The operation and maintenance of DMF are much simpler, especially without requiring a long start-up period, as no complicated biological process is involved. (3) DMF presents a high modularity, which allows resizing or up-scaling. (4) The process can be operated in discontinuous mode, therefore it can be easily adapted to seasonal flow changes of feed wastewater as well as feed composition. (5) DMF can produce superior permeate quality that meets EU water discharge or reuse standards, as it can efficiently reject micropollutants and microplastics. Therefore, DMF is especially interesting for wastewater treatment in order to recover water, nutrients and energy. The interest in DMF is growing because the conventional wastewater treatment process faces challenges in terms of global sustainability on energy consumption and greenhouse gas emission. In contrast, DMF can achieve wastewater treatment with emphasizing minimization of energy consumption and $\mathrm{CO}_{2}$ emission. The rejected organics/ nutrients can be collected for further energy production (such as methane, hydrogen), nutrients ( $\mathrm{N}$ and $\mathrm{P}$ ) recovery, or valuable product commercialization (such as fertilizer). Overall, the DMF-based wastewater treatment system could potentially gain net energy and additional profits, achieving self-sufficient municipal wastewater treatment (Butler and MacCormick, 1996; Guilbaud et al., 2010; Hey et al., 2017; Ravazzini et al., 2005).

\subsection{Research Goals}

Achieving the secondary treatment goals in Iceland is hindered by several factors. First, Iceland has a very small population with a scattered distribution pattern, especially in rural areas. This creates a challenge to employ centralized wastewater treatment facilities in terms of implementation and economic feasibility. Second, the climatic conditions also present a challenge. Iceland is located just under the Arctic circle and therefore presents a cold climate with mean annual temperatures under $6{ }^{\circ} \mathrm{C}$, even during the warmest summer months the mean monthly temperatures remain under $14{ }^{\circ} \mathrm{C}$ (IMO, 2019). It is well known that secondary biological treatment is highly dependent on the temperature and the activated sludge prefers a temperature in the range of 20 to $25^{\circ} \mathrm{C}$. In addition, a biological treatment step has a longer start-up period and therefore a continuous feed flow is preferred (Hedaoo et al., 2012). This however, is not always feasible in remote areas in Iceland, as some regions are completely deserted during the winter months while busy with tourists in summer. Third, the wastewater has a relatively high inflow rate, specifically 1000-2500 L/capita/day in Iceland vs. < $400 \mathrm{~L} / \mathrm{capita}$ /day in Europe (Sævarsson, 2018). This, in turn, leads to extremely low organic concentrations which limits the secondary wastewater treatment efficiency. Fourth, conventional wastewater treatment for small communities is cost-intensive.

There is an urgent need to find a cost effective, flexible technology that can efficiently treat diluted municipal wastewater in small municipalities (1000 - 300000 habitations) in cold climate. This study, therefore, aims to develop a sustainable DMF system for wastewater treatment in Iceland by analyzing the technical feasibility on a lab-scale. DMF membrane fouling mechanisms will be explored and DMF fouling control strategies with less chemical usage and energy consumption will be proposed.

The experimental research includes three key components:

(1) Which membrane is most applicable for Icelandic high volume, low organic concentration wastewater? 
Different commercial membranes display different characteristics, which could lead to dissimilar DMF performance and water quality. Several commercial membranes were selected and tested based on threshold flux determination method under identical operation conditions. The membrane showing the best performance was selected for further study.

(2) Which operation conditions are most important and how can they be optimized?

To optimize DMF operation, the effects of different operation conditions on DMF performance were studied, including feed pressure, crossflow velocity, filtration mode, and physical/chemical membrane cleaning protocols. Finally, a long-term operation of DMF was conducted under the optimal operation conditions. To explore membrane fouling mechanisms, the membrane fouling rate and membrane fouling resistance distribution were analyzed. Meanwhile, direct observation of in-situ DMF membrane fouling via optical coherence tomography (OCT) was performed.

(3) Which components are removed by filtration and which fouling type is dominant?

To examine permeate water quality and identify major foulants, their detailed component compositions were analyzed by a series of advanced analytical equipment. This allows to further assess the effect of operation conditions of DMF on the permeate water quality and membrane fouling mechanisms.

\subsection{Thesis Organization}

First, the technological background of membrane filtration and recent developments in DMF will be explained. Next, methods for the experimental part of the research will be presented. The practical part will begin with the threshold flux determination to find a suitable membrane for the simulated Icelandic wastewater. The chosen membranes will further be used for short-term continuous filtrations with physical and chemical cleaning for resistance and fouling analysis. In a next step, the effect of feed pressure, flow velocity, flushing type and intervals on filtration performance will be studied during intermittent filtration. Fouling will be observed during filtrations with OCT. Feed, permeate and fouling samples taken during intermittent filtration will be analyzed to determine fouling mechanisms. The conclusions will summarise the results and discuss future research. 



\section{Technological Background}

\subsection{Membrane Filtration}

Membrane filtration is a separation process through size exclusion. Certain components pass through a thin and semipermeable membrane, while others presenting greater sizes than the membrane pore sizes are rejected (Crittenden et al., 2012; Singh and Hankins, 2016). The driving force in pressure-driven membrane filtration is the pressure difference between feed side and permeate side, also called the transmembrane pressure (TMP). Depending on the pore size, membranes are sorted into four different categories: MF, UF, nanofiltration (NF) and reverse osmosis (RO), where MF has the largest pore size, followed by UF, NF and RO (Singh and Hankins, 2016). These membranes produce different permeate qualities, which makes the technique favorable for water reuse (Ravazzini et al., 2005). Generally, MF and UF membranes are widely used in wastewater treatment processes.

The MF/ UF filtration process can be conducted under two different filtration modes: deadend and crossflow, as depicted in Figure 6. During dead-end filtration, the flow is perpendicular to the membrane and there is no crossflow velocity along the membrane surface. Thus, the rejected components are drawn towards the membrane and build-up on the surface. The accumulated components on the membrane tend to reduce the permeate flux. During crossflow operation, the feed flows in parallel to the membrane. The shear force created by the crossflow velocity reduces depositions of components on the membrane and therefore decreases the building-up and the thickness of a cake layer. This allows longer operation with less cleaning or operation at a higher flux (Crittenden et al., 2012; Singh and Hankins, 2016).

There are two different operation modes: constant flux and constant TMP. When the filtration is performed at a constant flux, the TMP increases continuously in order to maintain the flux over the filtration time. On the other hand, when operating in a constant TMP mode, the flux decreases over time due to continuous accumulation of foulants on the membrane surface and inside the membrane. Usually, large-scale systems are operated at constant flux mode to maintain the water production at a constant level. (Crittenden et al., 2012; Singh and Hankins, 2016) 


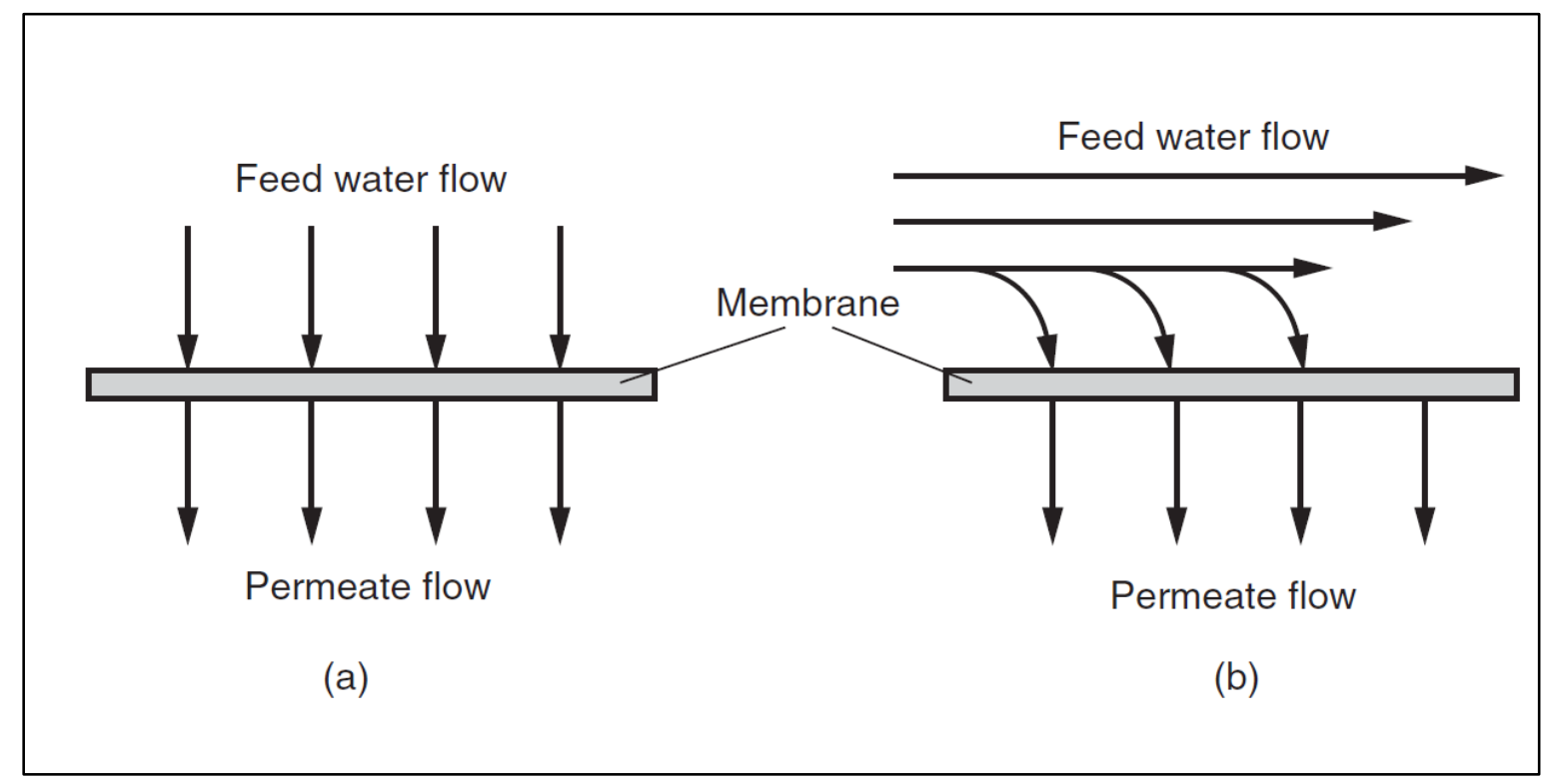

Figure 6. A schematic diagram of dead-end ( $a$ ) and crossflow (b) filtration (Crittenden et al., 2012).

\subsection{Membrane Fouling}

Fouling is a key limiting factor in membrane filtration. Consequences of severe fouling are not only flux decline or pressure increase but also reduced system efficiency, shorter membrane lifespans, lost service time and cost increase. There are several ways to characterize fouling. First, in terms of membrane fouling mechanisms, fouling can be attributed to pore blocking, pore constriction and the formation of a cake (Figure 7). In detail, pore blocking takes place when a particle occupies the opening of a pore. Thus, the number of open pores is reduced and therefore the flow declines. Pore constriction is the fouling when feed components are adsorbed inside the membrane pores. This leads to a reduced void volume inside the membrane. A cake layer is formed when greater-sized particles deposit on the membrane surface and build up a porous layer (Crittenden et al., 2012). Second, fouling can be divided into reversible fouling, irreversible fouling, and irremovable fouling based on cleaning protocols. Cake layer fouling is mostly reversible by physically backwashing the membrane. The fouling which cannot be easily removed by physical cleaning but can be removed by chemical cleaning is called irreversible fouling. The fouling which cannot be removed by both physical and chemical cleaning is called irremovable fouling (Crittenden et al., 2012). Third, different fouling types are also associated with different feed components, such as particle fouling, biofouling or inorganic fouling. During the treatment of wastewater, biofouling is predominant in most of cases (Crittenden et al., 2012; Hey et al., 2017; Singh and Hankins, 2016). 


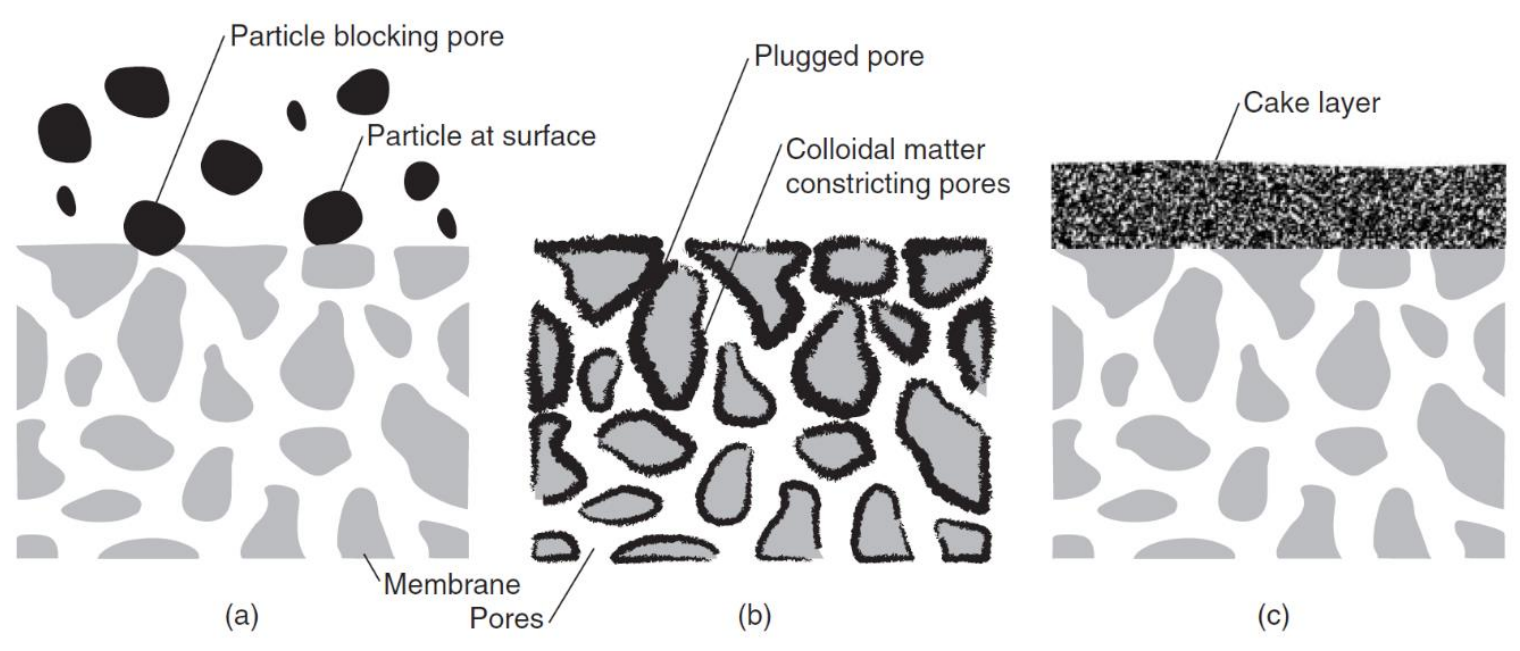

Figure 7. Fouling mechanisms: (a) Pore blocking, (b) pore constriction and (c) cake layer formation (Crittenden et al., 2012)

To alleviate membrane fouling, fouling control measures are critically important during membrane filtration (Singh and Hankins, 2016). The first option is to optimize operational parameters, such as flux, temperature, shear force, pressure, $\mathrm{pH}$ and intermittent filtration could be beneficial for better membrane performance (Crittenden et al., 2012; Shi et al., 2014; Singh and Hankins, 2016). The second option is to perform optimized physical and chemical cleaning. For example, the most commonly-used physical cleaning procedures are flushing/ backflushing and air sparging (Crittenden et al., 2012; Saleh and Gupta, 2016; Singh and Hankins, 2016). Other physical cleaning methods also include particle scouring, membrane vibration, and spacer vibration (Tan et al., 2019; Wu, 2019; Wu et al., 2019). In these approaches, the crossflow velocity creates shear to prevent depositions of foulants on the membrane. Furthermore, chemical cleaning is combined with physical cleaning to enhance cleaning efficiency by regularly adding chemicals to a flushing or backwash water flow. To increase the cleaning efficiency, cleaning solutions at a higher temperature could be adopted. It should be noted that employing chemicals can lead to an increase of capital costs, a shortened membrane lifetime and the creation of secondary pollutants (Saleh and Gupta, 2016). The third option is to pre-treat the feed water to remove potential foulants by sedimentation or pre-filtration, coagulation and flocculation (Crittenden et al., 2012; Singh and Hankins, 2016; Šstar-Turk et al., 2005). The fourth option is to select a suitable membrane. Membrane types are manifold and differ in material, pore sizes, hydrophobicity, porosity, surface roughness and chemistry, stability against mechanical stress, chemicals and high temperatures, biological stability, internal structure and tortuosity. The choice of membrane greatly influences the filtration process, due to its compatibility with the feed solution. The optimal membrane offers a high selectivity and permeability and low fouling, is physically and chemically stable over a long time operation and available at low costs (Crittenden et al., 2012; Singh and Hankins, 2016). 


\subsection{Treatment Performance of DMF}

The application of DMF in treating various types of wastewater has been well documented in the literature (Akbari et al., 2002; Guilbaud et al., 2010; Hey et al., 2018; Kim et al., 2007a; Kim et al., 2007b; Koyuncu, 2003; Lin et al., 2016; Lòpez Zavala et al., 2014; Oh et al., 2016; Ramona et al., 2004; Ravazzini et al., 2005; Šostar-Turk et al., 2005; Woźniak and Prochaska, 2014; Zhao et al., 2019) (See Appendix 1). It is noted that lab-scale research work on this field is greatly progressing, but very limited pilot or full-scale practical application have been reported.

In activated sludge $+\mathrm{MF}$ / UF or MBR processes, the factors influencing permeate quality and membrane performance have been elaborately investigated at various scale sizes and summarized in several review articles (Drews, 2010; Meng et al., 2017; Wu and Fane, 2012). However, during DMF of wastewater, the factors influencing the permeate quality and membrane performance are rarely explained in the literature. A limited number of reported lab-scale studies pointed out that the membrane type and material, pore size, pretreatment of feed water, and fouling control methods have affected the permeate quality and membrane performance (Guilbaud et al., 2010; Kim et al., 2007b; Ravazzini et al., 2005; Wu, 2019), but such evaluation was based on observations during short filtration periods (a few hours to a few days). For example, NF and RO processes can produce treated wastewater with better quality than MF/ UF due to their relatively smaller pore size (NF) or dense membrane (RO) natures. However, the effect of membrane pore size on membrane performance was not conclusive as different types of wastewaters and different operation conditions (flux, pressure, filtration time, etc.) were employed in these reported studies.

During the DMF of wastewater, membrane fouling is a major challenge due to the relatively higher organic matter in the feed. It has been reported that cake layer fouling was potentially predominant, which's reversibility could be achieved by physical membrane cleaning (Akbari et al., 2002; Kim et al., 2007a; Li et al., 2008; Ravazzini et al., 2005). Other research work also highlighted the potential of irreversible fouling in affecting membrane performance (Kimura et al., 2017; Lateef et al., 2013). Nevertheless, serious membrane fouling could lead to an increase in DMF operation costs due to higher feed pressures, decreased membrane lifetime and more frequent cleanings (Anis et al., 2019). Therefore, proper membrane fouling control strategies are necessary to improve DMF performance.

\subsection{DMF Performance Improvement Strategies}

\section{Enhanced Physical and Chemical Cleaning}

Aeration is widely used as an effective physical membrane fouling control method, however, it requires a great amount of energy (> 0.2 to $0.3 \mathrm{kWh} / \mathrm{m}^{3}$ water) (Judd, 2006) and the dissolved oxygen could facilitate aerobic degradation of organic matter (i.e., loss of recoverable organic matter). Thus, alternative physical cleaning approaches with less energy consumption, such as membrane vibration and particle scouring were proposed in DMF processes. In a hollow fiber membrane filtration system, compared to particle scouring, membrane vibration appeared to have greater fouling control potential (Kimura et al., 2017). In another study, the vibrated membrane also showed less serious membrane fouling than aerated membrane, therefore, leading to less membrane cleaning requirements for DMF system (Mezohegyi et al., 2012). 
The chemical enhanced backwash (CEB) is commonly applied to alleviate membrane fouling in order to achieve sustainable membrane operation. Not surprisingly, it was also a promising strategy to improve DMF performance as cleaning chemicals could remove both organic matter and inorganic matter involved in the development of membrane fouling. Previous studies have shown that in a DMF system, CEB using $\mathrm{NaOCl}$ and/ or citric acid (e.g., $0.1 \% \mathrm{NaOCl}$ and $0.2 \%$ of citric acid, 30 s every $12 \mathrm{~h}$-filtration; or $1 \%$ of citric acid, 30 $\mathrm{s}$ every $6 \mathrm{~h}$-filtration) could lead to considerately less membrane fouling compared to periodical water backwash (Kimura et al., 2017; Lateef et al., 2013). Accordingly, a higher concentration factor (i.e., a higher organic recovery ratio, up to $75 \%$ ) of feed water could be achieved during long-term DMF of wastewater (Lateef et al., 2013).

After such CEB, the discharge of the used chemicals into environments could have a negative environmental impact. Alternatively, ozonated water (ozone concentration at 0.2 to $0.8 \mathrm{mg} / \mathrm{L})$ was adopted for backwashing a metal membrane $(0.1 \mu \mathrm{m})$ during filtrating municipal wastewater (Kim et al., 2007a). It was found that intermittent backwash with the ozonated water could improve flux recovery (92\%) compared to air backwashing (47\%), due to more effective removal of small foulants attached on the surface and in the membrane pore structure by ozonated water. Due to the robust nature of the metal membrane, shortterm exploration ( 1 min per 30 min filtration) to ozonation did not cause membrane integrity loss. Nevertheless, the CEB process was cost-intensive and could lead to shortening of the membrane lifespan, especially for organic membranes (Jin et al., 2017; Kimura et al., 2017). Optimization of CEB frequency and intensity during DMF is of importance (Kimura et al., 2017).

\section{Pretreatment of Feed Water}

Wastewater generally contains great amounts of suspended solids and dissolved organic and inorganic matter, which could be potential membrane foulants in DMF (Lateef et al., 2013). Pretreatment of feed water before it was fed to the direct membrane system was suggested as a fouling control method, aiming to remove potential membrane foulants.

For example, Lòpez Zavala et al. (Lòpez Zavala et al., 2014) employed low-cost felt and compressed polyester filters to remove total solids and organics from the powder detergent greywater, which's removal ratios reached $>30 \%$. Accordingly, the flux decline of the following direct UF filtration was significantly alleviated (improved almost 5 times). For high-pressure NF/ RO membrane processes, pretreatment of feed water by low-pressure cartridges or MF/ UF membranes was applied (Boddu et al., 2016; Koyuncu, 2003; ŠostarTurk et al., 2005), which aimed to remove part of potential particulate and colloidal foulants. This could benefit to achieve long-term sustainable operation of NF/RO processes and reduce chemical usage for membrane cleaning. Notably, the additional capital and maintenance costs of the pretreatment systems are required, which have rarely been reported in the literature. Whether pretreatment could benefit to minimize the overall costs of DMF system needs to be further carefully illustrated.

\section{Integration with Coagulation/ Adsorption}

The dissolved or colloidal organics and inorganics in wastewater can potentially contribute to irreversible fouling of direct MF/ UF processes, which required intensive chemical cleaning (Kimura et al., 2017; Lateef et al., 2013). Shifting such irreversible fouling to cake layer fouling could be achieved by adding coagulants into the feed water, aiming to build greater-sized flocs (i.e., decreasing dissolved and colloidal substances). Such flocs tend to 
form a cake layer on the MF/ UF membrane surface, which could be readily removed by proper physical cleaning (Huang et al., 2017). In addition, coagulation/ flocculation also performed roles in enhancing retention of smaller-sized soluble organics, nutrients, micropollutants by promoting particle formation, which allowed improving permeate quality to meet stricter discharge or reuse standards (Hey et al., 2018).

Different types of inorganic $\left(\mathrm{Al}_{2}\left(\mathrm{SO}_{4}\right)_{3}\right.$ and $\left.\mathrm{FeCl}_{3}\right)$ and organic (polyacrylamide) coagulants have been attempted for lab-scale direct MF/ UF of municipal wastewater (Gong et al., 2017; Huang et al., 2017; Jin et al., 2016; Jin et al., 2017). The research findings highlighted that the use of all tested coagulants in direct MF/ UF processes led to an increase in membrane performance, compared to those without coagulants. However, the inorganic and organic coagulants showed different behaviors in influencing membrane performance. Researchers observed that the organic coagulant, such as polyacrylamide, was found to have an optimal dosing concentration, above or below which the membrane performance decreased. While, the dosed amount of inorganic coagulants, such as $\mathrm{Al}_{2}\left(\mathrm{SO}_{4}\right)_{3}$ and $\mathrm{FeCl}_{3}$, appeared to be positively linear to the membrane flux improvement; even when they were dosed at high concentrations $(60 \mathrm{mg} / \mathrm{L})$, membrane performance was not negatively affected (Huang et al., 2017). As municipal wastewater varies significantly in its composition, the inorganic coagulants seemed to be more suitable for fouling alleviation. In addition, $\mathrm{FeCl}_{3}$ could interact with phosphorus in wastewater, thus it could be a favorable option for simultaneously treating wastewater and recovering nutrients during DMF (Huang et al., 2017).

To further improve the membrane performance in coagulation enhanced DMF processes, combining coagulation with other processes is recommended in several studies. For example, the coagulation effectiveness in improving membrane performance could be further enhanced by adding adsorbents such as powder activated carbon (Gong et al., 2017). The addition of these adsorbents aimed to further improve the removal of colloid and soluble foulants. Although a stronger cake layer containing adsorbents increased the filtration resistance, it tended to significantly decrease the irreversible fouling, thus leading to a reduced overall fouling (Gong et al., 2017). The coupling of intermittent aeration and coagulation was also attempted (Jin et al., 2016). In this combination, the coagulant helped produce loose and porous flocs and intermittent aeration helped control the thickness of such a porous cake layer on the membrane, therefore achieving a slower decline of membrane permeability. Apparently, compared to continuous aeration, intermittent aeration would require less energy consumption, benefiting to sustainable long-term operation. Alternatively, periodical air-backflushing was proposed to implement with a coagulation process (Jin et al., 2017). The coagulation process mainly contributed to the reduction of both cake layer resistance and irreversible resistance, while periodical air-backflushing not only benefitted to maintain sustainable long-term filtration by maximizing membrane filterability, but also improved organic matter recovery ratio (> $90 \%$ vs. $70 \%$ under coagulation with intermittent aeration condition) (Jin et al., 2016; Jin et al., 2017).

\subsection{Frontiers of Research and Gaps in Knowledge of DMF}

So far, very limited full-scale plants involving DMF have been reported. It is thought to be associated with several challenges that need to be solved before scaling-up. Membrane 
fouling is a major issue and limiting factor. In conventional MBRs, microbial relevant fouling has been identified as predominant membrane fouling (Meng et al., 2017; Wu and Fane, 2012). While, in DMF processes, the components (such as organics, inorganics, suspended solids) in wastewater are potential foulants, which could contribute to severe membrane fouling. However, the membrane fouling mechanisms of DMF processes are seldom studied in detail, which require a comprehensive investigation, especially in real application cases. The different membrane fouling mechanisms may require specific membrane fouling control strategies for DMF processes compared to those applied in MBRs (Jin et al., 2017).

For instance, it has been reported that periodical chemical cleaning was efficient in reducing irreversible fouling, which helped achieve sustainable membrane operation (Kimura et al., 2017; Lateef et al., 2013; Tran et al., 2015). However, the use of a great amount of chemicals could increase operation costs and produce secondary pollutants. More, it would shorten the lifespan of membranes, especially for organic membranes (Jin et al., 2017; Kimura et al., 2017; Sajjad et al., 2019; Xiao et al., 2018). Similarly, the use of chemicals (coagulants, flocculants, activated carbon) in DMF processes could contribute to membrane fouling alleviation by maintaining cake layer filterability and reversibility, but this also led to increased capital costs and chemical wastes (Huang et al., 2017; Jin et al., 2017; Wu, 2019). More, whether the presence of these chemicals in the concentrated resource stream could influence subsequent biological resource recovery processes (such as anaerobic digestion) is also not well illustrated. Nevertheless, it is suggested to reduce the usage of chemicals in DMF by optimizing the cleaning procedure (pressure, temperature) as well as by reducing the free volume of the system (Guilbaud et al., 2010).

In contrast, physical pretreatment of wastewater appears to be more desirable due to relatively less negative environmental impacts, such as the use of low-pressure cartridge or mesh filters for low-pressure MF/ UF processes (López Zavala et al., 2014). However, pretreatment processes require not only additional capital and maintenance costs, but also additional space. Thus, further optimization of feed water pretreatment and membrane cleaning methods in DMF is of paramount significance, especially during a long-term operation period with variation of feed water composition.

An alternative solution for improvement of DMF performance is to develop new membranes with increased antifouling properties. One reported study focused on developing novel antifouling membranes and the lab-scale testing findings displayed their good performances in membrane fouling alleviation (Oh et al., 2016). However, long-term filtration testing for these novel membranes are still lacking, which indeed is necessary in order to achieve sustainable membrane operation and promote their commercialization. Towards fabricating less fouling-sensitive membranes, identification of membrane fouling mechanisms (cake layer fouling predominant or irreversible fouling predominant; dominant fouling components) is crucially important, requiring intensive investigation (Akbari et al., 2002).

In view of the absence of large-scale DMF processes on the market, further research needs to be emphasized on (1) membrane fouling control technologies of DMF, especially towards low energy consumption, less chemical usage, and easier operation and maintenance; (2) development of novel membranes, especially having mechanically robust nature with lowcost environmental-friendly materials and self-cleaning properties; (3) comprehensive economic analysis, life cycle assessment, and carbon footprint analysis of different DMF processes in order to identify the most suitable system configuration for further scale-up. 



\section{Materials and Methods}

\subsection{Materials}

The feed water was collected weekly at the Ulu Pandan wastewater reclamation plant in Singapore and stored at $4{ }^{\circ} \mathrm{C}$. Before use, the wastewater was warmed up to room temperature $\left(22^{\circ} \mathrm{C}\right)$. The wastewater in Singapore had a higher organic level than that in Iceland, therefore the wastewater was diluted with tap water to simulate Icelandic wastewater (COD of $\sim 70 \mathrm{mg} / \mathrm{L}$ ).

Several flat sheet membranes with different characteristics were selected and tested in order to identify a suitable membrane for DMF of wastewater. The membranes used in this study and their characteristics are listed in Table 1.

Table 1. The flat sheet membranes used in this study

\begin{tabular}{llll}
\hline Material & Pore size & MF/ UF & Brand (Country) \\
\hline PVDF & $0.45 \mu \mathrm{m}$ & MF & Merck Millipore (USA) \\
PVDF & $0.2 \mu \mathrm{m}$ & MF & Merck Millipore (USA) \\
PVDF & $0.08 \mu \mathrm{m}$ & MF & Toray (Japan) \\
PVDF & $250 \mathrm{kDa}$ & UF & Synder Filtration (USA) \\
RC & $100 \mathrm{kDa}$ & UF & Amicon Bioseparation (USA) \\
PES & $100 \mathrm{kDa}$ & UF & Pall Corporation (USA) \\
PAN & $100 \mathrm{kDa}$ & UF & Synder Filtration (USA) \\
\hline
\end{tabular}

\subsection{Laboratory Experiments}

\subsubsection{Experimental Setup}

The setup of the DMF system is shown in Figure 8. Two identical batch-scale membrane modules (Figure 9) with different membrane areas were used $\left(\mathrm{A}_{1}=0.001643 \mathrm{~m}^{2}\right.$ and $\mathrm{A}_{2}=0.002178 \mathrm{~m}^{2}$ ). The setups were built for this study in the SMTC laboratory at the Nanyang Technological University (Singapore). 


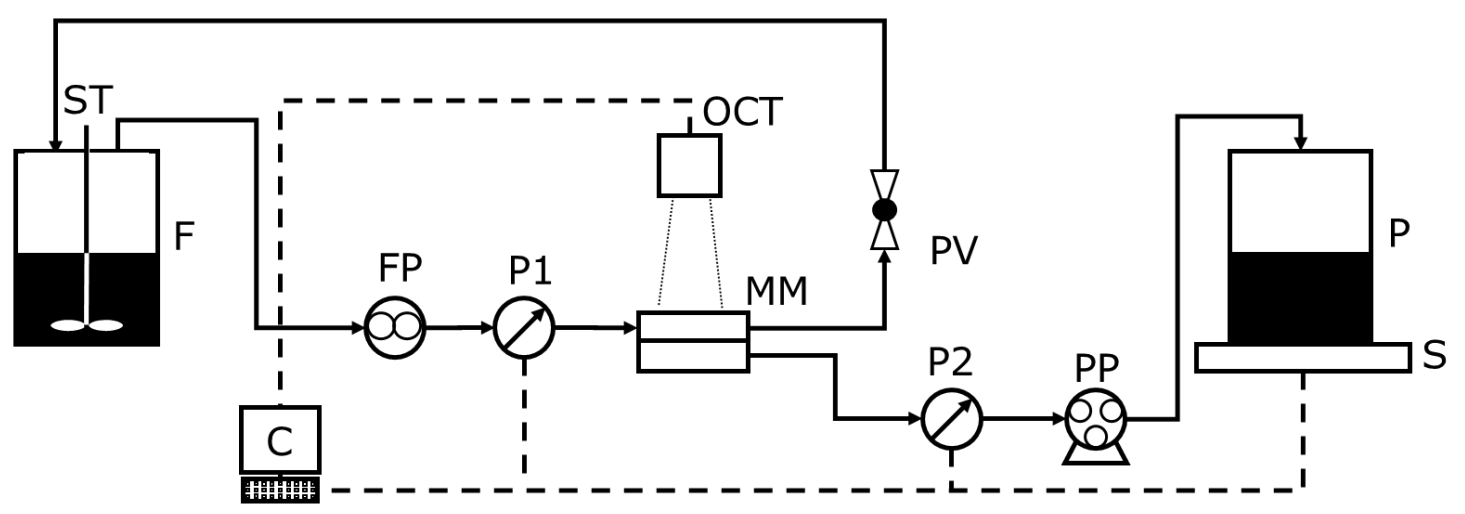

\begin{tabular}{|c|c|c|c|c|c|}
\hline C & $=$ & Computer & OCT & $=$ & Optical coherence tomography \\
\hline $\mathrm{F}$ & $=$ & Feed tank & P2 & $=$ & Permeate pressure gauge \\
\hline ST & $=$ & Stirrer & PV & $=$ & Pressure valve \\
\hline FP & $=$ & Feed pump & PP & $=$ & Permeate pump \\
\hline P1 & $=$ & Feed pressure gauge & $\mathrm{P}$ & $=$ & Permeate tank \\
\hline MM & $=$ & Membrane module & $\mathrm{S}$ & $=$ & Scale \\
\hline
\end{tabular}

Figure 8. Batch-scale DMF setup

The feed wastewater was stored in a feed tank, in which the stirrer maintained the feed wellmixed. The feed was delivered to the filtration cell by a gear pump and the pressure valve was applied to regulate the feed flowrate and feed pressure. The filtrations were run at a flowrate of $0.2,0.4$ or $0.8 \mathrm{~L} / \mathrm{min}$ (LPM), which correspond to a flow velocity of $0.1,0.2$ and $0.4 \mathrm{~m} / \mathrm{s}$ respectively. During the filtration, the permeate water was driven through the membrane by a peristaltic pump at a constant flow and the collected permeate water was measured by a balance. The rejected water flow was returned back to the feed tank. Both balance and pressure gauges were connected to a computer, which recorded data via a LabView software (National Instruments, USA).

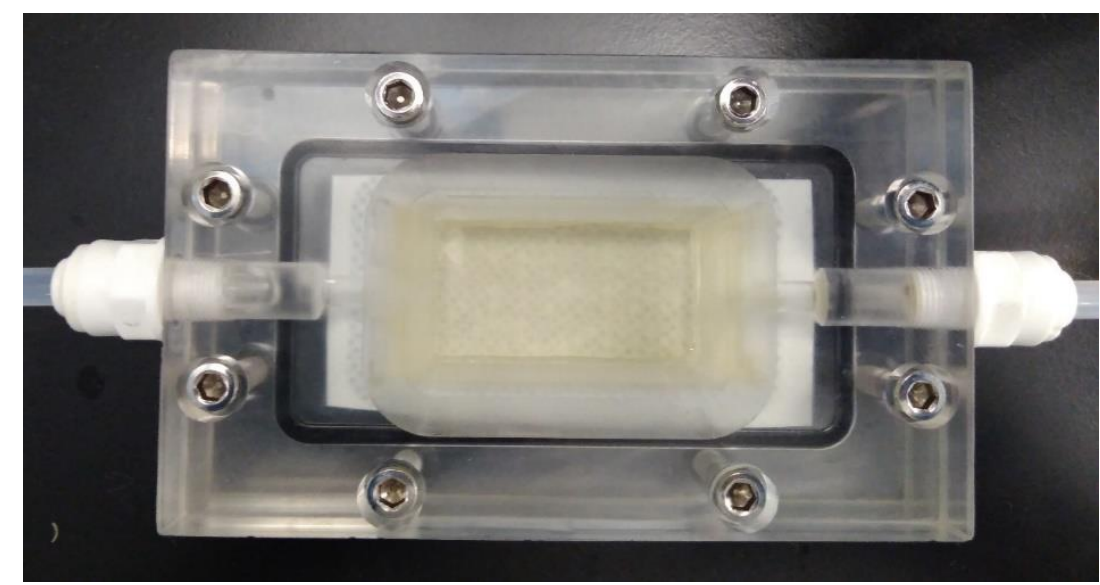

Figure 9. Filtration cell used in DMF setup 
The DMF setup with an auto-controlled cleaning system is shown in Figure 10. A cleaning system with auto-controlled functions were installed in the DMF setup. During membrane filtration, the check valve 1 (CV1) and solenoid valve (SV1) were turned-on, but the check valve 2 (CV2) and solenoid valve 2 (SV2) were turned off, which prevented the feed water flowing into the cleaning system and vice versa during the cleaning. A heating plate was located under the cleaning water tank to heat the cleaning water if necessary.

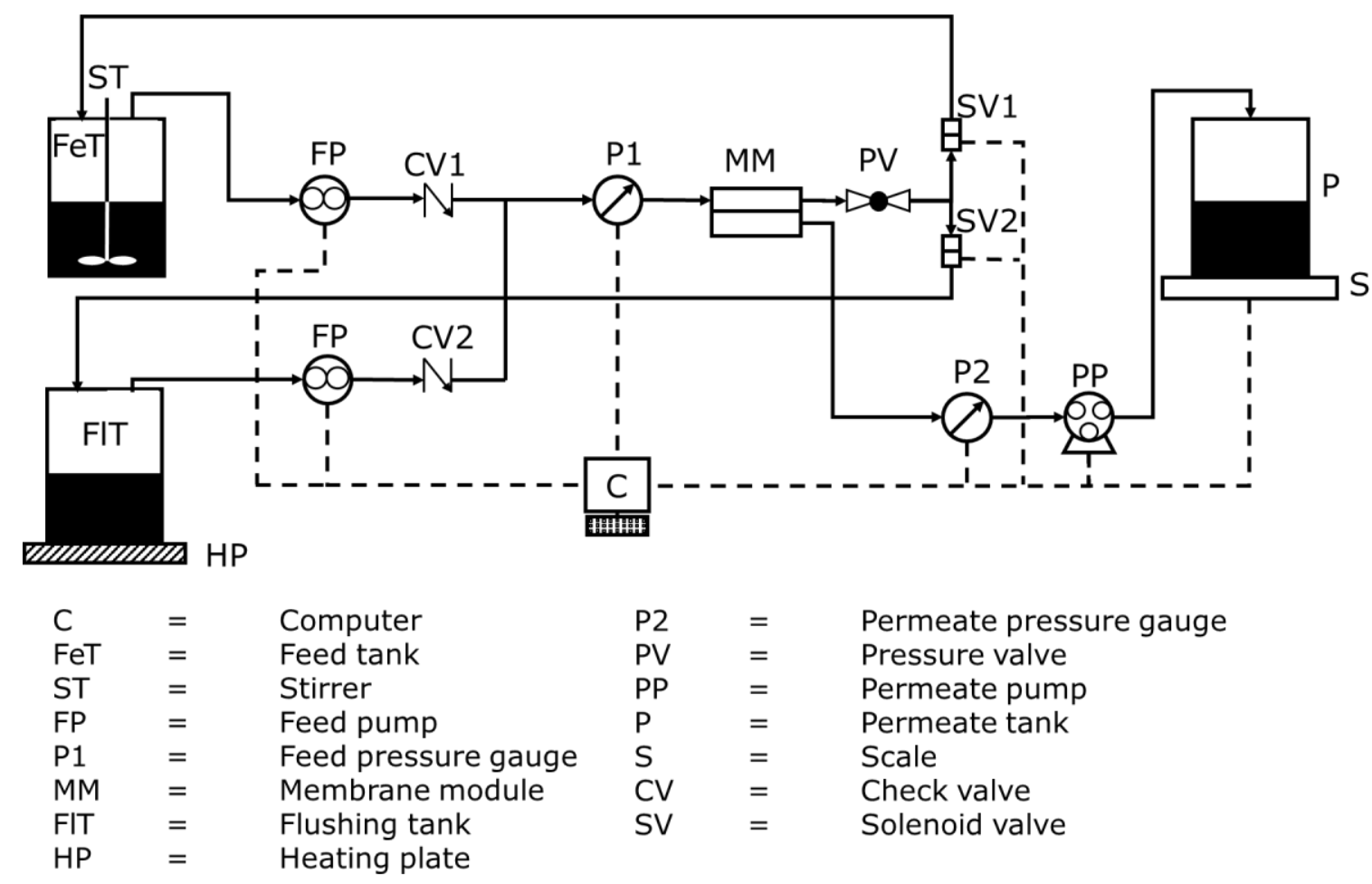

Figure 10. Batch-scale DMF setup with an auto-controlled cleaning system.

The membrane flux $\mathrm{J}\left(\mathrm{L} / \mathrm{m}^{2} \mathrm{~h}, \mathrm{LMH}\right)$, referring to the volumetric water flux across the membrane, was calculated as Eq. 1 (Crittenden et al., 2012).

$$
J=\frac{Q}{A} \quad[E q .1]
$$

$\mathrm{J}=$ Flux

$\mathrm{Q}=$ Flow rate

$\mathrm{A}=$ Membrane area 


\subsubsection{Operation}

The operation conditions in this study are summarized in Table 2. For each test, before filtration of wastewater, distilled water filtration was performed for $30 \mathrm{~min}$ in order to evaluate clean membrane permeability.

Table 2. Operation conditions in this study

\begin{tabular}{|c|c|c|c|c|c|c|}
\hline \multicolumn{2}{|c|}{ Conditions } & Membrane & $\begin{array}{c}\text { Feed } \\
\text { Pressure } \\
(\mathrm{kPa})\end{array}$ & $\begin{array}{c}\text { Crossflow } \\
\text { Velocity } \\
(\mathrm{m} / \mathrm{s})\end{array}$ & $\begin{array}{c}\text { Permeate } \\
\text { Flux } \\
(\mathrm{LMH})\end{array}$ & $\begin{array}{l}\text { Cleaning } \\
\text { protocol }\end{array}$ \\
\hline \multicolumn{2}{|c|}{$\begin{array}{c}\text { Stage I (Threshold Flux } \\
\text { Determination) }\end{array}$} & $\begin{array}{l}\text { PVDF } \\
(0.45,0.2, \\
0.08 \mu \mathrm{m} \\
\text { and } \\
250 \mathrm{kDa}) \\
\text { RC } \\
(100 \mathrm{kDa}) \\
\text { PES } \\
(100 \mathrm{kDa})\end{array}$ & $\begin{array}{l}8 \text { and } \\
50\end{array}$ & 0.1 & 5 to 40 & None \\
\hline \multirow{2}{*}{$\begin{array}{c}\text { Stage II } \\
\text { (Optimization } \\
\text { of DMF) }\end{array}$} & $\begin{array}{l}\text { Resistance } \\
\text { Analysis }\end{array}$ & $\begin{array}{l}\text { PVDF } \\
(0.08 \mu \mathrm{m}) \\
\text { RC } \\
(100 \mathrm{kDa})\end{array}$ & $\begin{array}{l}8 \text { and } \\
50\end{array}$ & 0.1 & 25 & $\begin{array}{l}\text { Distilled } \\
\text { water and } \\
0.5 \% \\
\mathrm{NaOCl} \\
\text { flushing } \\
\left(25^{\circ} \mathrm{C}\right)\end{array}$ \\
\hline & $\begin{array}{l}\text { Inter- } \\
\text { mittent } \\
\text { Filtration }\end{array}$ & $\begin{array}{l}\text { PVDF } \\
(0.08 \mu \mathrm{m})\end{array}$ & $\begin{array}{l}8 \text { and } \\
50\end{array}$ & $\begin{array}{l}0.1,0.2 \\
\text { and } 0.4\end{array}$ & 25 & $\begin{array}{l}\text { Wastewater } \\
\text { and tap } \\
\text { water } \\
\text { flushing } \\
(25 \text { and } \\
\left.50^{\circ} \mathrm{C}\right)\end{array}$ \\
\hline \multicolumn{2}{|c|}{$\begin{array}{c}\text { Stage III (Long-Term } \\
\text { Operation) }\end{array}$} & $\begin{array}{l}\text { PVDF } \\
(0.08 \mu \mathrm{m})\end{array}$ & 8 & 0.4 & 25 & $\begin{array}{l}\text { Tap water } \\
\left(50^{\circ} \mathrm{C}\right) \text { and } \\
\text { periodical } \\
0.5 \% \\
\mathrm{NaOCl} \\
\text { flushing } \\
\left(50^{\circ} \mathrm{C}\right)\end{array}$ \\
\hline
\end{tabular}

* $\mathrm{NaOCl}$ is widely used membrane cleaning chemical and the applied concentration of $\mathrm{NaOCl}$ referred to the manufacturer's manual.

\subsection{Threshold Flux Determination}

The concept of 'critical flux' is defined as the maximum flux below which, no fouling occurs whereas above the critical flux fouling builds up. As the critical flux concept is proposed based on a single component feed, it is not strictly applicable for multiple-component feeds, 
such as wastewater. Because each component has its own critical flux, the multiplecomponent feed has instead a range of critical fluxes. In such cases, it is more meaningful to determine a 'threshold flux', which is the flux value that distinguish a region of low fouling rate from a high fouling rate (Field and Pearce, 2011; Luo et al., 2013). The threshold flux of the wastewater was determined using the following protocol: (1) the flux was incrementally increased at 15 min intervals, (2) the slope of the TMP profile (dTMP/dt) was calculated at each flux step (see Eq. 2) and (3) the threshold flux, at which the regression lines of the low fouling region and the high fouling region intersects, was determined.

$$
\frac{d T M P}{d t}=\frac{T M P_{n}-T M P_{n-1}}{15 \min }[E q .2]
$$

$\begin{array}{llll}\frac{d T M P}{d t} & =\quad \text { TMP increase over time } & {\left[\frac{k P a}{h}\right]} \\ \text { TMP }_{\mathrm{n}}= & \text { TMP at time of } 15 \text { min } & {[\mathrm{kPa}]} \\ \mathrm{TMP}_{\mathrm{n}-1}=\quad \mathrm{TMP} \text { at time of } 0 \text { min } & {[\mathrm{kPa}]}\end{array}$

\subsection{Membrane Resistance Analysis}

The fouling resistances in a membrane filtration can be calculated using Eq. 3 (Crittenden et al., 2012).

$$
J=\frac{\Delta P}{\mu\left(\mathrm{R}_{m}+\mathrm{R}_{i m}+\mathrm{R}_{i r}+\mathrm{R}_{c}\right)}[E q .3]
$$

$\mathrm{J}=$ Flux

[LMH]

$\Delta \mathrm{P}=\mathrm{TMP}$

$[\mathrm{kPa}]$

$\mu=$ Viscosity of permeate water at filtration temperature

$[\mathrm{mPa} \mathrm{s}]$

$\mathrm{R}_{\mathrm{m}}=$ Membrane resistance

$[1 / \mathrm{m}]$

$\mathrm{R}_{\mathrm{im}}=$ Irremovable fouling resistance

$[1 / \mathrm{m}]$

$\mathrm{R}_{\mathrm{ir}} \quad=\quad$ Irreversible fouling resistance

$[1 / \mathrm{m}]$

$\mathrm{R}_{\mathrm{c}}=$ Cake layer resistance

$[1 / \mathrm{m}]$

The membrane resistance was calculated based on the data during filtration of the clean water. The cake layer resistance was calculated based on the resistance difference before and after physical flushing. The irreversible resistance was calculated based on the resistance 
difference before and after chemical cleaning. The remaining irremovable resistance was calculated based on the resistance difference after the chemical cleaning and the membrane resistance (Wu et al., 2017).

\subsection{Fouling Observation via OCT}

OCT is a 3D imaging technique, which allows high resolutions on micron scale. The diagnostic is carried out with ultrashort pulses or near-infrared light. Long wavelength light is used, which can penetrate deep into the examined medium while photodetectors capture the reflected signal. The basic principle is shown in Figure 11 (Brezinski, 2006; Sim and Fane, 2017). As OCT can be conducted in situ, it allows direct observation of membrane filtration in a non-invasive and non-destructive mode (Dreszer et al., 2014). The scans provide information on the dynamic thickness and structure of the fouling layer (growth and detachment of the biofilm) during the filtration. Thus, precise information about cake layer properties can be attained, such as coverage or specific depositions, without disturbing the process (Dreszer et al., 2014; Sim and Fane, 2017).

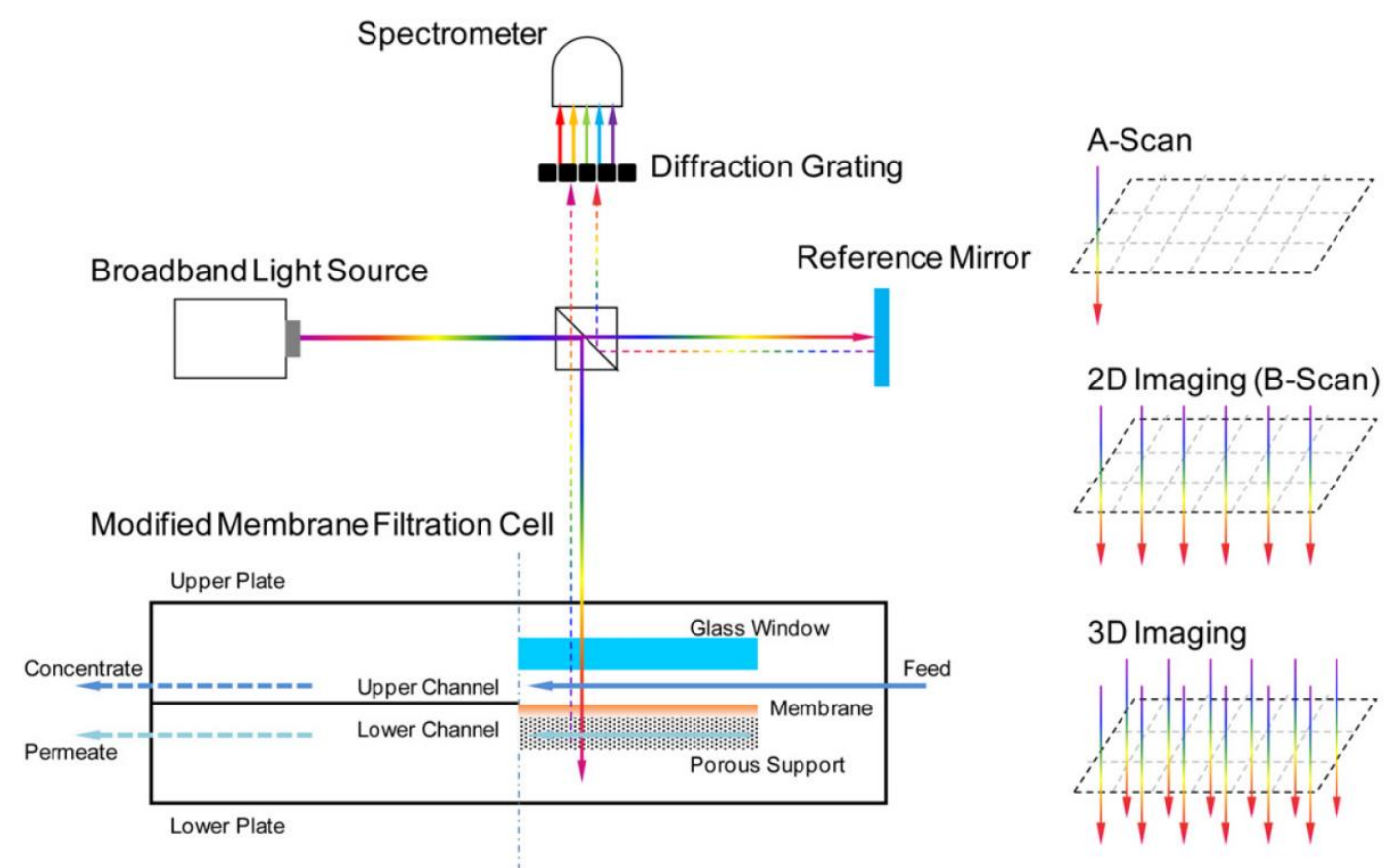

Figure 11. Basic principle of Fourier-domain OCT of fouling process in a membrane filtration cell (Sim and Fane, 2017)

In this study, an OCT equipment (Thorlabs, USA) was integrated with the DMF system and a quartz plate on the upper part of the filtration cell functioned as an optical window for performing OCT scans. The OCT images were collected at a certain time interval and the collected images were processed by Thorimaging software (Thorlabs, USA). 


\subsection{Analysis of Water Quality and Foulants Characteristics}

\subsubsection{Samples}

The feed and permeate samples were periodically collected from the DMF system. The cake layer foulant samples were collected by putting the fouled membrane in a beaker with $30 \mathrm{~mL}$ of distilled water and then sonicating it for 3 to $6 \mathrm{~min}$.

\subsubsection{Feed and Permeate Strength (COD, TSS, TOC)}

The Chemical Oxygen Demand (COD) was measured using the COD measurement kit (Hach, USA) according to the manufacturer's manual and a spectrophotometer (DR3900, Hach, USA). The resulting COD represented mostly colloidal and soluble organics. As their size is comparable to MF/ UF pores, they are considered as major foulants. Next, TSS were analyzed using standard methods (APHA, 1998). Third, the Total Organic Carbon (TOC) was measured using a TOC/ TN analyzer (Shimadzu, Japan) after filtering the samples with a $0.45 \mu \mathrm{m}$ filter.

\subsubsection{Liquid Chromatography - Organic Carbon Detection (LC- OCD)}

LC-OCD analysis was employed to quantify the soluble organic fraction in the samples. A LC-OCD analyzer (DOC-Labor, Germany) with an automated size-exclusion chromatography integrated with an organic Carbon detector and organic Nitrogen detector was used. After filtration $(0.45 \mu \mathrm{m})$, the collected filtrate was further separated according to molecular weight (MW), e.g. biopolymers (typically MW $>20 \mathrm{kDa}$ ), humic substances (MW $1000 \mathrm{Da}$ ), building blocks (MW 300-500 Da), low molecular weight (LMW) organics acids (MW < $300 \mathrm{Da}$ ), and neutrals (MW < $300 \mathrm{Da})$ (Huber et al., 2011).

\subsubsection{Inductively Coupled Plasma - Optical Emission Spectroscopy (ICP-OES)}

The cations (Na, $\mathrm{Mg}$, and $\mathrm{Ca}$ ) in the sample were analyzed by ICP-OES (Perkin Elmer, USA) after filtration $(0.45 \mu \mathrm{m})$ and acidification (with a $1 \% \mathrm{HNO}_{3}$ solution) of the sample.

\subsubsection{Fluorescence Spectrophotometer}

A fluorescence spectrophotometer (Agilent Technologies, USA) was used for obtaining an excitation-emission matrix (EEM) fluorescence spectra in the wavelength range of 280 to $550 \mathrm{~nm}$. Excitation and emission slits were set at $10 \mathrm{~nm}$ with a scanning speed of $1000 \mathrm{~nm} / \mathrm{min}$. Fluorescence regional integration was applied to describe the volumetric percentage of a given component with the following relationships between the organic components and the EEM spectra regions: (I) for aromatic proteins I - like substances, excitation wavelength (Ex) $<250 \mathrm{~nm}$ and emission wavelength (Em) $<330 \mathrm{~nm}$; (II) for aromatic protein II - like substances, Ex $<250 \mathrm{~nm}$, and Em between $330 \mathrm{~nm}$ and $380 \mathrm{~nm}$; (III) for fulvic acid-like substances, Ex $<250 \mathrm{~nm}$ and $\mathrm{Em}>380 \mathrm{~nm}$; (IV) for soluble 
microbial by-product-like substances, Ex between 250 and $280 \mathrm{~nm}$, and Em < $380 \mathrm{~nm}$; and (V) for humic acid-like substances, Ex > $280 \mathrm{~nm}$ and Em > $380 \mathrm{~nm}$ (Chen et al., 2003).

\subsubsection{Flow Cytometer}

After the sample was taken, $1 \mathrm{~mL}$ of unfiltered sample was immediately treated with LIVE/DEAD ${ }^{\circledR}$ BacLight $^{\mathrm{TM}}$ bacterial viability kit (Invitrogen, USA) according to the manufacturer's instructions. The analysis in a flow cytometer (BD Bioscience, USA) resulted in the dead and live cell count.

\subsubsection{Adenosin Triphosphate (ATP)}

For ATP measurements, the Kit CheckLite 250 Plus (Kikkoman, Japan) was used. After the sample was taken, the unfiltered sample was immediately mixed with ATP-releasing agent and luciferin-luciferase and its bioluminescence was measured in a luminometer (Lumitester C-110 by Kikkoman, Japan).

\subsubsection{Ion Chromatography (IC)}

The concentrations of anions $\left(\mathrm{F}, \mathrm{Cl}, \mathrm{NO}_{2}, \mathrm{Br}, \mathrm{NO}_{3}, \mathrm{PO}_{4}\right.$ and $\left.\mathrm{SO}_{4}\right)$ in the sample were analyzed by the Dionex ICS 1100 (Thermo Fisher Scientific, USA) after filtering $(0.45 \mu \mathrm{m})$ the sample.

\subsubsection{Goniometer}

The contact angles of the physically cleaned (by sonication) and dried membrane samples were examined by a contact angle analyzer (Data Physics Instruments, Germany).

\subsubsection{Fourier-Transform Infrared Spectroscopy (FTIR)}

The transmittance spectrum of the function groups on the physically cleaned (by sonication) and dried membrane samples were examined by a FTIR (Shimadzu, Japan).

\subsubsection{Scanning Electron Microscopy (SEM)}

After filtration, the membrane was carefully removed from the filtration cell and pre-treated using a Heraeus vacuum oven (Thermo Scientific, USA) at $40{ }^{\circ} \mathrm{C}$ for $15 \mathrm{~h}$ to remove the moisture content. After the dried membrane was sputter-coated with platinum, a field emission scanning electronic microscope (JEOL, Japan) was used to characterize the membrane surface morphology. 


\section{Results and Discussion}

\subsection{Threshold Flux Determination}

To identify the suitable membrane during DMF of wastewater, the threshold fluxes of these membranes were examined. At a feed pressure of $50 \mathrm{kPa}$, the evolution of the dTMP/dt at each permeate flux is shown in Figure 12. The dTMP/dt did not increase significantly during the lower flux region, but after trespassing a certain flux, the curves showed steep increases. Shown in Figure 12a (for different UF membranes), the PVDF membrane ( $250 \mathrm{kDa}$ ) showed the steepest dTMP/dt increase pattern, followed by the PES (100 kDa). The RC membrane $(100 \mathrm{kDa})$ presented a relatively slow dTMP/dt increase pattern. Figure $12 \mathrm{~b}$ (for PVDF membranes with different pore sizes) indicated that the PVDF membranes with larger pore sizes $(0.45,0.2$, and $0.08 \mu \mathrm{m})$ had slower $\mathrm{dTMP} / \mathrm{dt}$ increase trends compared to that with a pore size of $250 \mathrm{kPa}$. In summary (Table 3), it was found that the threshold flux of the MF membranes $(0.45 \mu \mathrm{m}, 0.2 \mu \mathrm{m}$ and $0.08 \mu \mathrm{m})$ was $\sim 30 \mathrm{LMH}$, while the UF membranes had a threshold flux of 20 to $25 \mathrm{LMH}$. It is noted that even though both RC and PES membranes $(100 \mathrm{kDa})$ had a similar threshold flux, the flux increase of the RC membrane above the threshold flux was significantly less steep than the PES membrane, indicating better performance.

To further illustrate the effect of feed pressure on the threshold flux, the membranes, including PVDF membranes $(0.45 \mu \mathrm{m}, 0.2 \mu \mathrm{m}, 0,08 \mu \mathrm{m})$, and RC membrane (100 kDa), were used to perform threshold flux determination at a feed pressure of $8 \mathrm{kPa}$, as shown in Figure 13. Compared to the PVDF membrane $(0.2 \mu \mathrm{m})$ and $\mathrm{RC}$ membrane $(100 \mathrm{kDa})$, the PVDF membranes $(0.08$ and $0.45 \mu \mathrm{m})$ had relatively slower increases of the dTMP/dt. Therefore, the threshold flux values were 20, 20, 25, $30 \mathrm{LMH}$ for the PVDF $(0.2 \mu \mathrm{m}), \mathrm{RC}$ $(100 \mathrm{kDa}), \operatorname{PVDF}(0.45 \mu \mathrm{m})$, and PVDF $(0.08 \mu \mathrm{m})$, respectively (Table 3$)$. Especially, the PVDF membrane $(0.08 \mu \mathrm{m})$ had obvious lower dTMP/dt increase rates above the threshold flux. As shown in Table 3, less feed pressure could lead to a higher threshold flux for the tested membranes, i.e., better membrane performance. Based on the threshold flux results, PVDF membrane $(0.08 \mu \mathrm{m})$ and $\mathrm{RC}(100 \mathrm{kDa})$ were selected as suitable MF and UF membranes respectively for the following experiments.

It is well known that (1) MF membranes have larger pore sizes, thus, the permeate quality may not be superior compared to UF membranes; (2) MF membranes are capable to treat higher strength feeds with lower fouling potential. As this study focuses on wastewater treatment instead of wastewater reuse, the permeate quality of a MF membrane generally well meets the treated wastewater standards in EU (Barbosa et al., 2016; Hey et al., 2018).

On the other hand, both PVDF and RC membranes are made from organic materials, which are generally available at lower prices than inorganic membranes. However, their stability against harsh cleaning processes, for instance when chemicals and high shear are involved, is not as good as inorganic membranes. This study aims to lead to an adequate cleaning 
protocol, which reduces chemical usage compared to other membrane processes. Therefore, the chosen membranes promise to be compatible with the protocol.
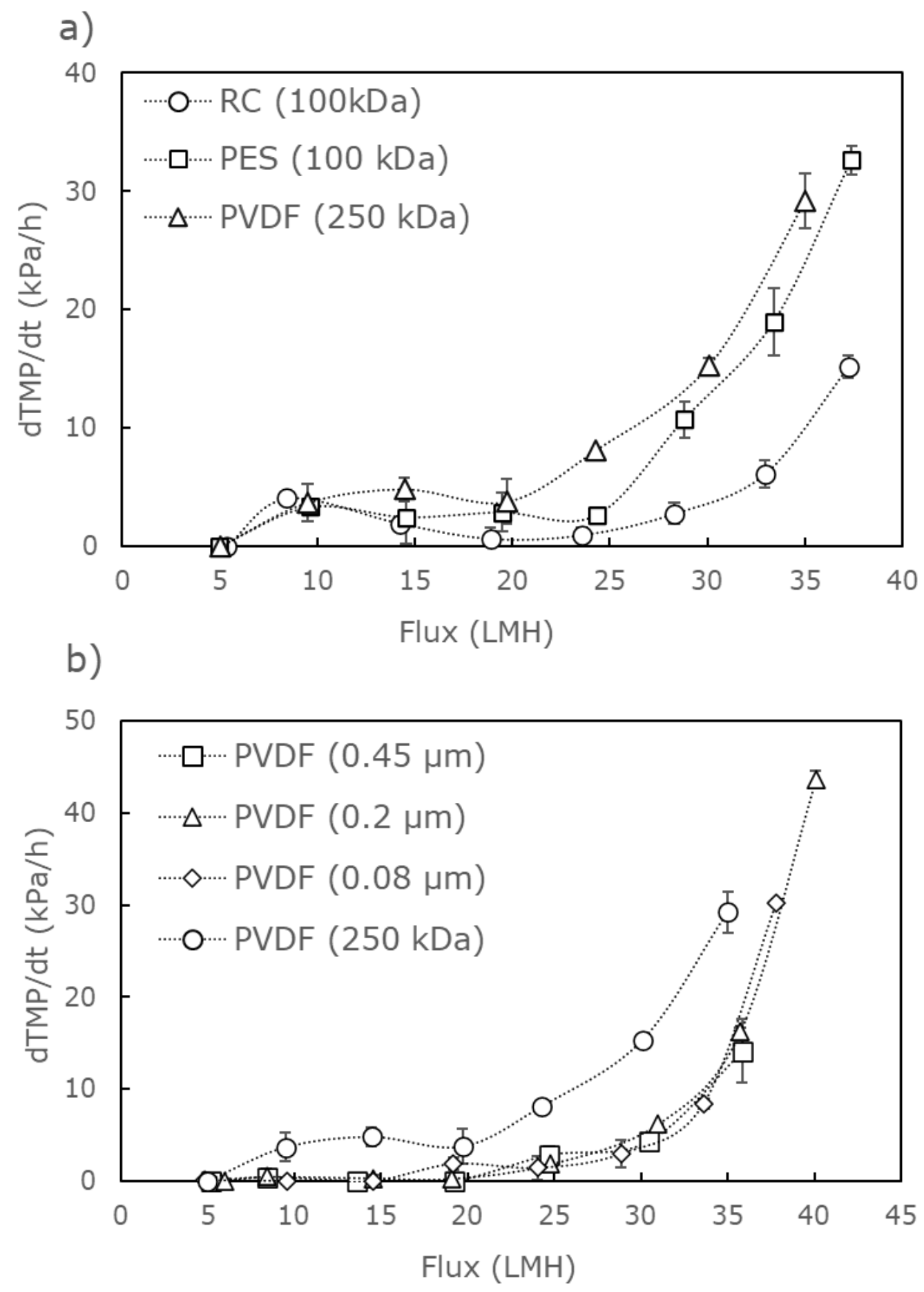

Figure 12. The dTMP/dt profiles for threshold flux determination (at a feed pressure of $50 \mathrm{kPa}$ ) 


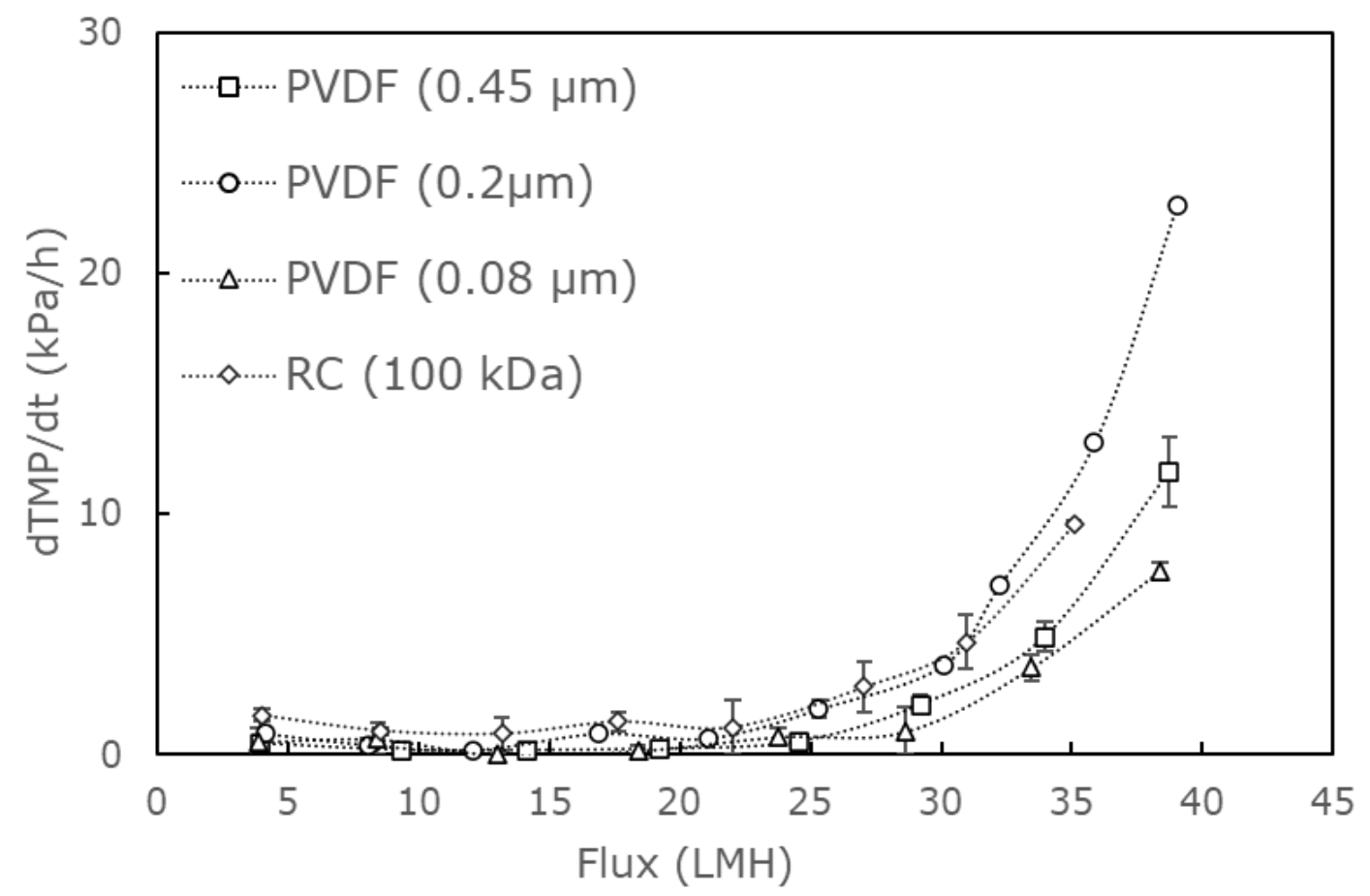

Figure 13. The dTMP/dt profiles for threshold flux determination (at a feed pressure of 8 $k P a)$

Table 3. A summary of threshold fluxes of the tested membranes

\begin{tabular}{cllccc}
\hline $\begin{array}{c}\text { Feed } \\
\text { pressure }\end{array}$ & $\begin{array}{c}\text { Membrane } \\
\text { material }\end{array}$ & Pore size & $\begin{array}{c}\text { Clean water } \\
\text { permeability }\end{array}$ & $\begin{array}{c}\text { Membrane } \\
\text { resistance }\end{array}$ & $\begin{array}{c}\text { Threshold } \\
\text { flux }\end{array}$ \\
\hline \multirow{5}{*}{$50 \mathrm{kPa}$} & & LMH/ kPa & $\times 10^{12} / \mathrm{m}$ & LMH \\
\hline & PVDF & $0.45 \mu \mathrm{m}$ & 1.27 & 2.8 & 30 \\
& PVDF & $0.2 \mu \mathrm{m}$ & 1.47 & 2.5 & 30 \\
& PVDF & $0.08 \mu \mathrm{m}$ & 1.83 & 2.0 & 30 \\
& RC & $250 \mathrm{kDa}$ & 1.12 & 3.2 & 20 \\
& PES & $100 \mathrm{kDa}$ & 1.39 & 2.6 & 25 \\
\hline \multirow{5}{*}{$8 \mathrm{kPa}$} & $100 \mathrm{kDa}$ & 0.83 & 4.4 & 25 \\
& PVDF & $0.45 \mu \mathrm{m}$ & 2.15 & 1.7 & 25 \\
& PVDF & $0.2 \mu \mathrm{m}$ & 1.75 & 2.1 & 20 \\
& PVDF & $0.08 \mu \mathrm{m}$ & 4.36 & 0.8 & 30 \\
& RC & $100 \mathrm{kDa}$ & 3.07 & 1.2 & 20 \\
\hline
\end{tabular}




\subsection{Effect of Operation Conditions on DMF Performance}

\subsubsection{Feed Pressure under Continuous and Intermittent Filtration}

The TMP evolution profiles of the PVDF and RC membranes during DMF of wastewater at different feed pressures is shown in Figure 14. First, during the lower feed pressure operation, the TMP of the PVDF filtration started at about $5 \mathrm{kPa}$ and stayed mostly constant during the first hour, which was similar to that of the RC membrane. After that, their TMP levels increased constantly with extending filtration time. Next, in the operation with the higher feed pressure condition, the initial TMPs were in similar ranges as those in the lowpressure operation. After that, the TMP increased faster for the RC membrane than the PVDF membrane.

The results clearly showed that the filtrations at the lower feed pressure were more sustainable due to their lower TMP increases. The influence of feed pressure on the PVDF membrane filtration was less significant compared to that on the RC membrane filtration. This result leads to the assumption that the dependence of the fouling on feed pressure is closely linked to the membrane characteristics. The interactions between foulants and RC membrane were stronger at the higher feed pressure than at the lower feed pressure, whereas such interactions with PVDF membranes may not be strongly associated with feed pressure.
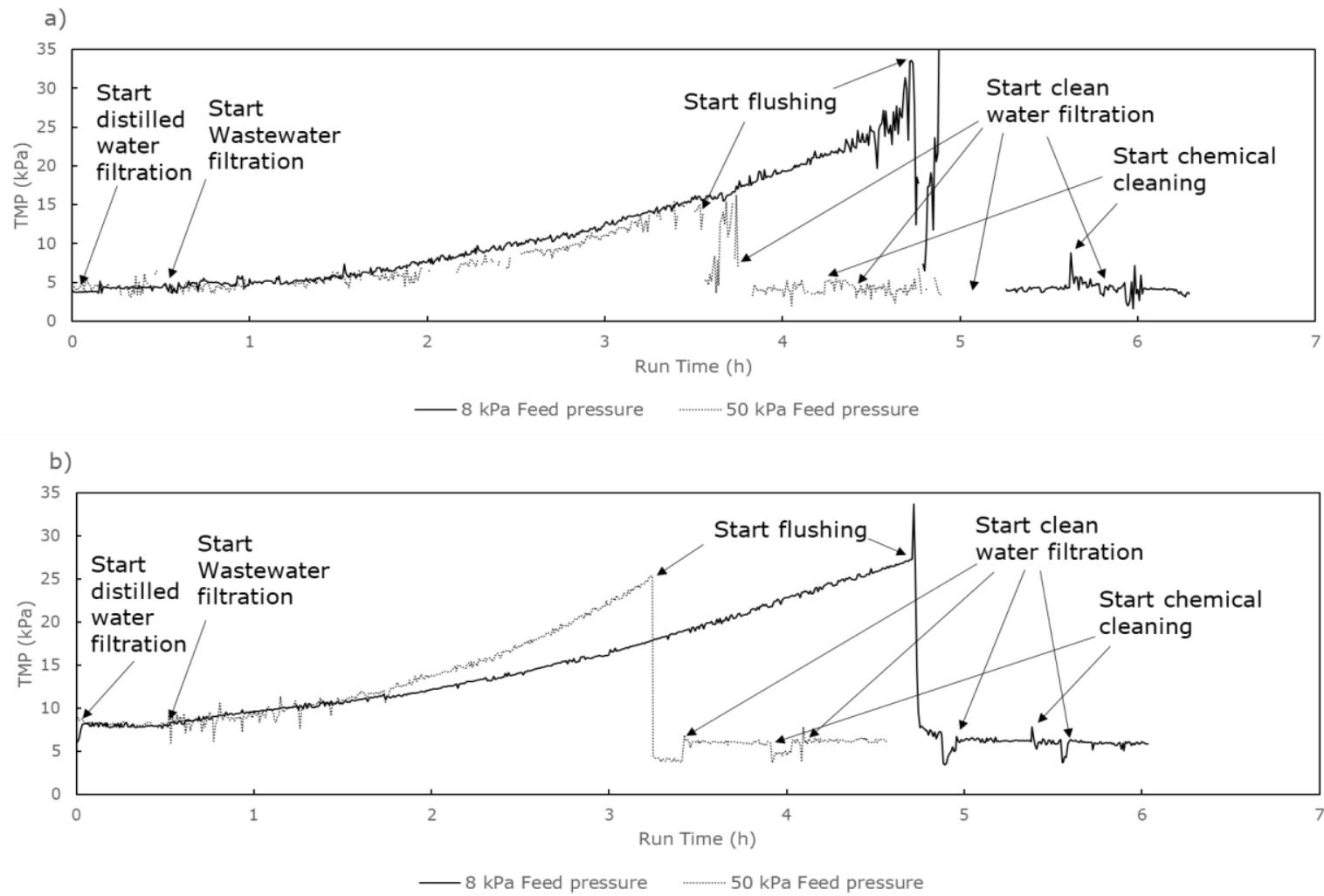

Figure 14. TMP evolution of PVDF (a) and RC membranes (b) at different feed pressures with clean water flushing and chemical cleaning after filtration 
Figure 15 shows the fouling resistance distributions of the fouled membranes. It was found that for both PVDF and RC membranes, the cake layer fouling was predominant (70 to 83\% of the total resistance) and almost no irreversible and irremovable fouling was detected under continuous filtration mode.

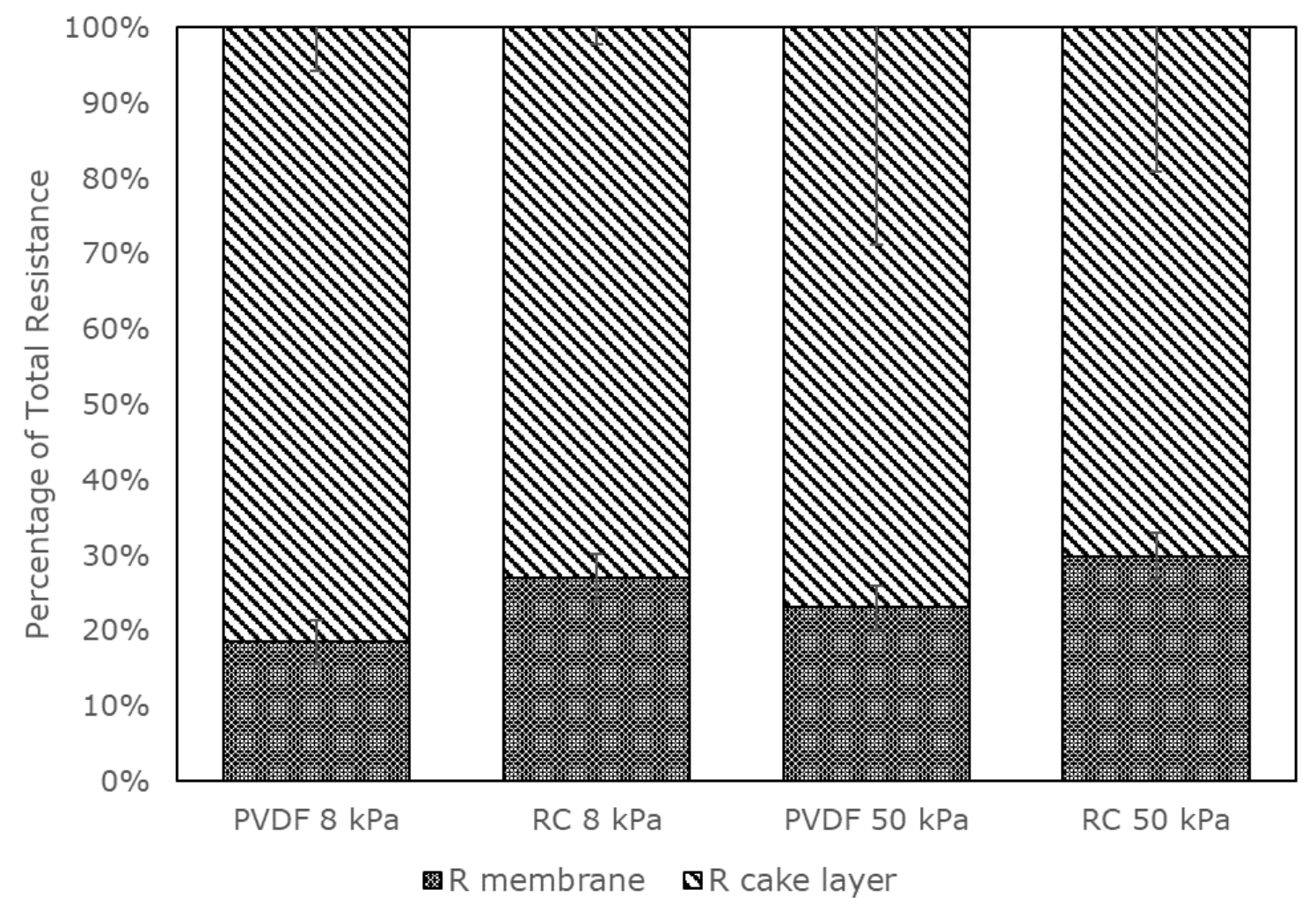

Figure 15. Filtration resistances at different feed pressures

\section{Intermittent Filtration}

As cake layer fouling was predominant during continuous DMF of wastewater, periodical physical cleaning (clean water flushing) was proposed to remove the cake layer from the membrane surface in order to achieve sustainable operation of DMF. To optimize the physical cleaning protocol, different filtration duration $(0.5,0.75,1.25,1.75$, and $2.75 \mathrm{~h})$ with a constant physical cleaning duration $(10 \mathrm{~min})$ were employed in this study. The filtration was performed for several cycles and membrane performance in terms of membrane fouling rate (dTMP/dt) and fouling resistance were examined, shown in Table 4.

As can be seen in Table 4, at the same filtration interval, the membrane fouling rate (dTMP/dt) was lower at a low feed pressure. Accordingly, both cake layer fouling and irreversible/ irremovable fouling resistances were lower at a low feed pressure than those at a high feed pressure. A low feed pressure was thought to allow the shear to transport the foulants away from the membrane due to less drag force towards the membrane, while under a high feed pressure the foulants could be pushed against the membrane by a greater drag force. 
Meanwhile, the effect of the filtration interval on membrane performance was more noticeable. The shorter filtration intervals lead to lower dTMP/dt and resistances values which indicated a more stable performance.

It was noted that cake layer fouling resistance and irremovable/ irreversible fouling resistance contributed equally to the total fouling under all the tested intermittent DMF filtration. Compared to the continuous DMF filtration, during intermittent filtration with periodical physical cleaning, the cake layer fouling contribution ratio decreased and irremovable/ irreversible fouling contribution ratio increased. Not surprisingly, after periodical removal of the cake layers, the cake layer fouling tended to shift to irremovable/ irreversible fouling. Overall, increasing the feed pressure correlated with an increase of the dTMP/dt and the PVDF membrane showed a better membrane performance than the RC membrane. Therefore, to maximize the treated water production, the PVDF membrane and filtration interval at $1.25 \mathrm{~h}$ under the lower feed pressure $(8 \mathrm{kPa})$ were applied for following intermittent filtration experiments.

Table 4. Membrane fouling rate (dTMP/dt) and membrane resistance during intermittent filtration with wastewater flushing at different feed pressures and filtration intervals.

\begin{tabular}{|c|c|c|c|c|c|c|}
\hline Membrane & $\begin{array}{c}\text { Feed } \\
\text { press- } \\
\text { ure }\end{array}$ & $\begin{array}{l}\text { Intermittent } \\
\text { frequency }\end{array}$ & $\begin{array}{c}\text { Filtration } \\
\text { cycles }\end{array}$ & $\begin{array}{l}\text { Averaged } \\
\mathrm{dTMP} / \mathrm{dt}\end{array}$ & $\begin{array}{c}\text { Cake } \\
\text { layer } \\
\text { resistance }\end{array}$ & $\begin{array}{l}\text { Irreversible } \\
\text { and } \\
\text { irremovable } \\
\text { resistance }\end{array}$ \\
\hline & $\mathrm{kPa}$ & $\mathrm{h}$ & & $\mathrm{kPa} / \mathrm{h}$ & $\times 10^{12} / \mathrm{m}$ & $\times 10^{12} / \mathrm{m}$ \\
\hline \multirow{5}{*}{ PVDF } & \multirow{3}{*}{8} & 0.5 & 9 & 9.23 & 0.4 & 0.3 \\
\hline & & 0.75 & 6 & 8.55 & 0.6 & 0.5 \\
\hline & & 1.25 & 4 & 10.52 & 0.7 & 0.7 \\
\hline & \multirow{2}{*}{50} & 1.25 & 4 & 32.39 & 1.4 & 1.4 \\
\hline & & 1.75 & 2 & 20.58 & 1.8 & 1.4 \\
\hline \multirow{4}{*}{$\mathrm{RC}$} & 8 & 1.25 & 4 & 14.61 & 0.8 & 1.3 \\
\hline & \multirow{3}{*}{50} & 1.25 & 4 & 38.90 & 1.8 & 2.0 \\
\hline & & 1.75 & 2 & 18.06 & 1.2 & 1.6 \\
\hline & & 2.75 & 2 & 19.57 & 1.6 & 2.5 \\
\hline
\end{tabular}

\subsubsection{Crossflow Velocity}

\section{Wastewater Flushing}

Figure 16 shows the membrane fouling rates (dTMP/dt) at different filtration velocities. The TMP increase was significantly lower at the higher flow velocities: after around $5 \mathrm{~h}$ of filtration, a dTMP/dt of $3.6 \mathrm{kPa} / \mathrm{h}$ was achieved at $0.4 \mathrm{~m} / \mathrm{s}$ of cross-flow velocity, while a $\mathrm{dTMP} / \mathrm{dt}$ of $20.62 \mathrm{kPa} / \mathrm{h}$ was presented at $0.1 \mathrm{~m} / \mathrm{s}$ of cross-flow velocity. With every cycle, the dTMP/dt increase was more obvious for the lower velocities and less significant for the higher velocities. Thus, the crossflow velocity seemed to be a key parameter to control the TMP increase. The higher shear force caused by increasing flowrate could reduce the deposition of foulants, thus alleviating the TMP increase during membrane filtration. 


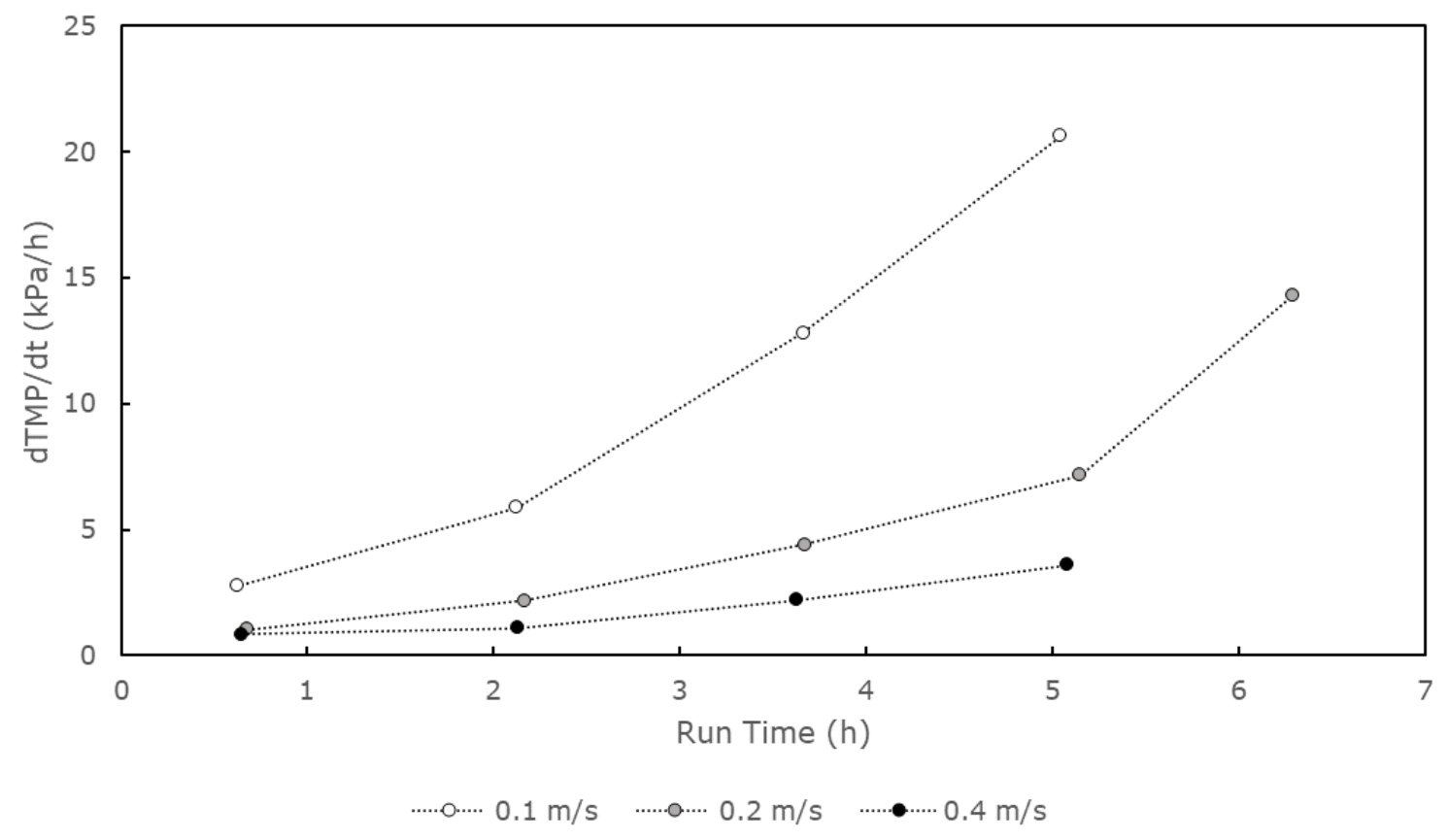

Figure 16. Membrane fouling rate $(d T M P / d t)$ during intermittent filtration with wastewater flushing at different flow rates

Figure 17 depicts the resistance of the intermittent filtrations with the PVDF membrane at different flow velocities. Clearly, increasing flow velocity led to decreased cake layer resistance. The cake layer resistance at $0.4 \mathrm{~m} / \mathrm{s}$ of velocity (mean: $1.2^{*} 10^{11} 1 / \mathrm{m}$ ) was considerately lower than that at $0.1 \mathrm{~m} / \mathrm{s}$ of velocity (mean: $6.9^{*} 10^{11} 1 / \mathrm{m}$ ). The irreversible and irremovable fouling resistances at a higher flow velocity were significantly lower than those at $0.1 \mathrm{~m} / \mathrm{s}$ of velocity. Even though the irreversible and irremovable fouling resistances at $0.4 \mathrm{~m} / \mathrm{s}$ of velocity started at a higher level than that at $0.2 \mathrm{~m} / \mathrm{s}$ of velocity, the increase was less steep throughout the filtration. These observations confirmed the dTMP/dt data, that the filtration was significantly more stable when the flow velocity was increased. 
a)

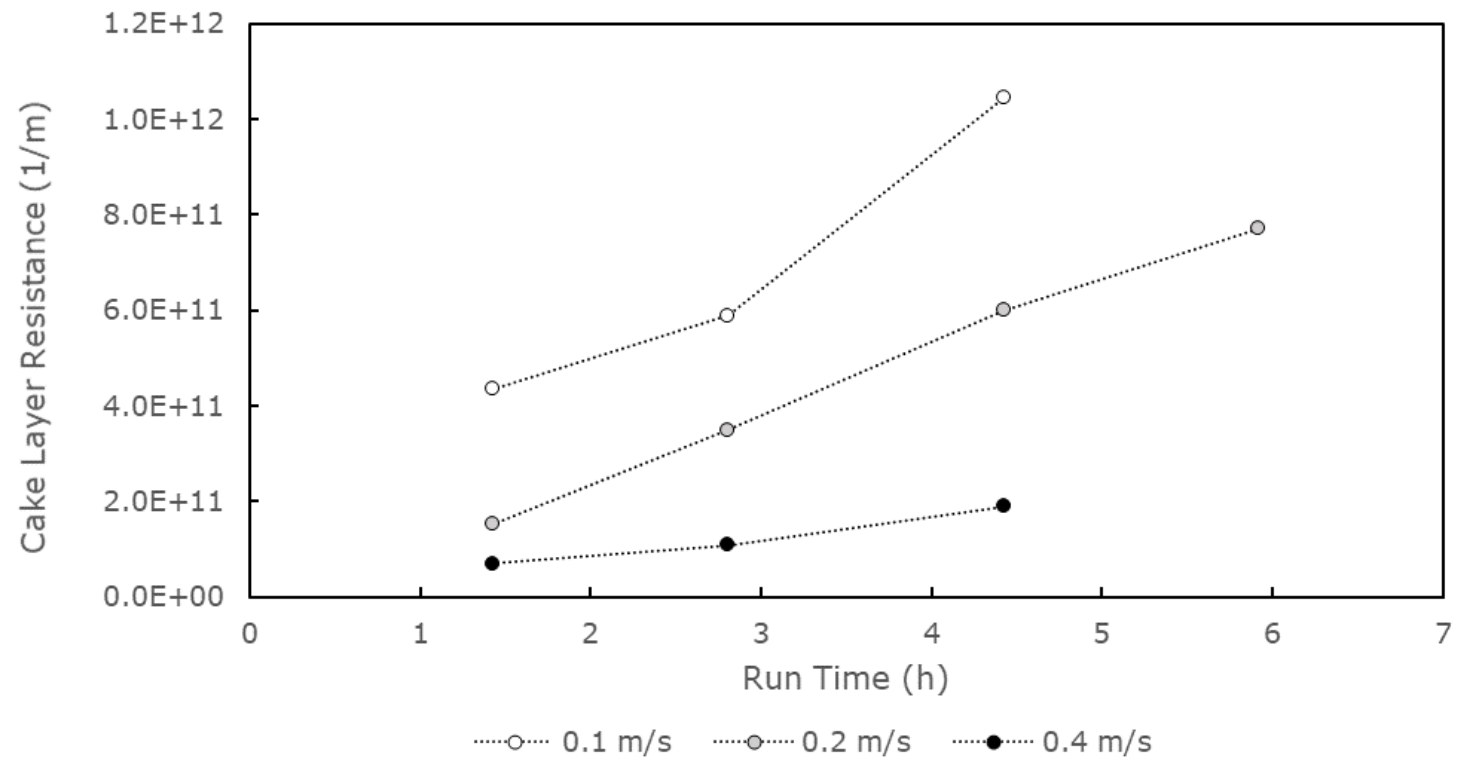

b)

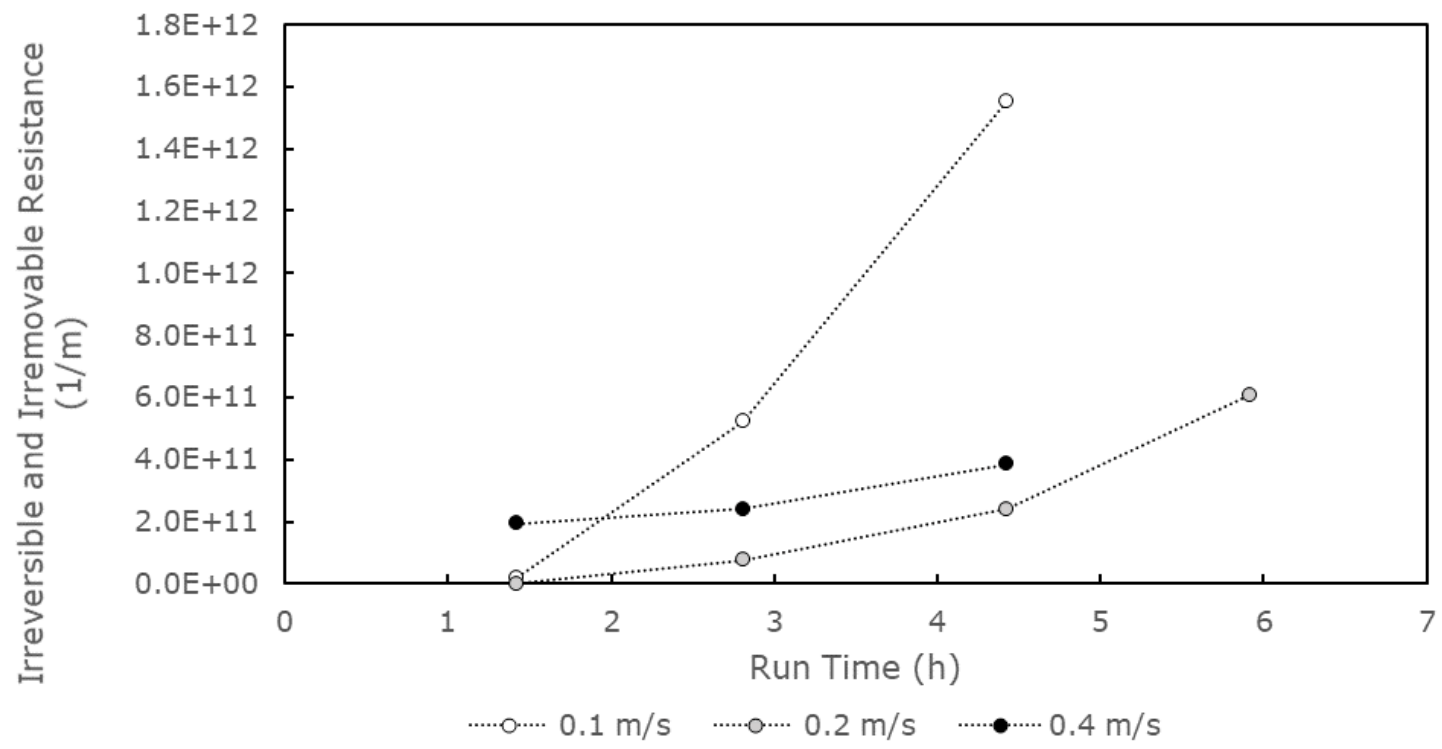

Figure 17. Cake layer (a) and irreversible and irremovable (b) fouling resistances at various flow velocities during intermittent filtration with wastewater flushing $\left(25^{\circ} \mathrm{C}, 0.1\right.$ $m / s)$.

\subsubsection{Cleaning Protocol}

\section{Tap Water Flushing}

The PVDF membranes were further tested for intermittent filtration with tap water flushing at 25 and $50{ }^{\circ} \mathrm{C}$, which is shown in Figure 18. The dTMP/dt of the filtration with wastewater flushing was clearly higher than those when cold or heated tap water were used (after approximately 5 . With extending filtration time, the differences between these conditions 
appeared to be significant. Further, the flushing with heated tap water led to a significantly lower dTMP/dt increase than flushing with cold tap water or wastewater. The results of the wastewater flushing filtration suggested a greater tendency of foulant accumulation on or in the membrane. Based on the experimental data, using heated tap water for flushing could be a crucial factor for stable operation. Besides the mechanical scrubbing of the membrane, the higher temperatures increase the solubility of fouling substances and thus favor their removal from the membrane.

Figure 19 shows the dTMP/dt results of intermittent filtrations with $50{ }^{\circ} \mathrm{C}$ tap water flushing at various flushing and filtration flow velocities $(0.1,0.2$ and $0.4 \mathrm{~m} / \mathrm{s})$. During the filtrations run at the lower flow rate $(0.1 \mathrm{~m} / \mathrm{s})$ which was increased to 0.2 and $0.4 \mathrm{~m} / \mathrm{s}$ during flushing, the TMP increased faster (mean dTMP/dt: 6.01 and $9.48 \mathrm{kPa} / \mathrm{h}$ respectively) than at the filtrations at a constant flowrate for filtration and flushing. On the other hand, when the filtration and flushing was run at the same flowrate, the filtrations with higher flow velocities showed a lower TMP increase, compared to that at $0.1 \mathrm{~m} / \mathrm{s}(0.1 \mathrm{~m} / \mathrm{s}: 3.62 \mathrm{kPa} / \mathrm{h}, 0.2 \mathrm{~m} / \mathrm{s}$ : $2.94 \mathrm{kPa} / \mathrm{h}$ and $0.4 \mathrm{~m} / \mathrm{s}: 0.54 \mathrm{kPa} / \mathrm{h})$. This phenomenon can be explained by the relation between flow velocity and TMP. When the flow velocity was increased, the TMP also increased. The higher TMP prevented membrane relaxation for foulant removal and potentially compressed the cake layer on the membrane. The tightly attached cake layer foulants thus turned into irreversible fouling. However, the TMP after flushing was still lower than that before flushing. This indicates that loosely attached cake layer foulants were removed during flushing. On the other hand, when filtration and flushing were performed at the same flow velocity, the filtration stability was improved. These results indicate the importance of high shear for long-term filtration.

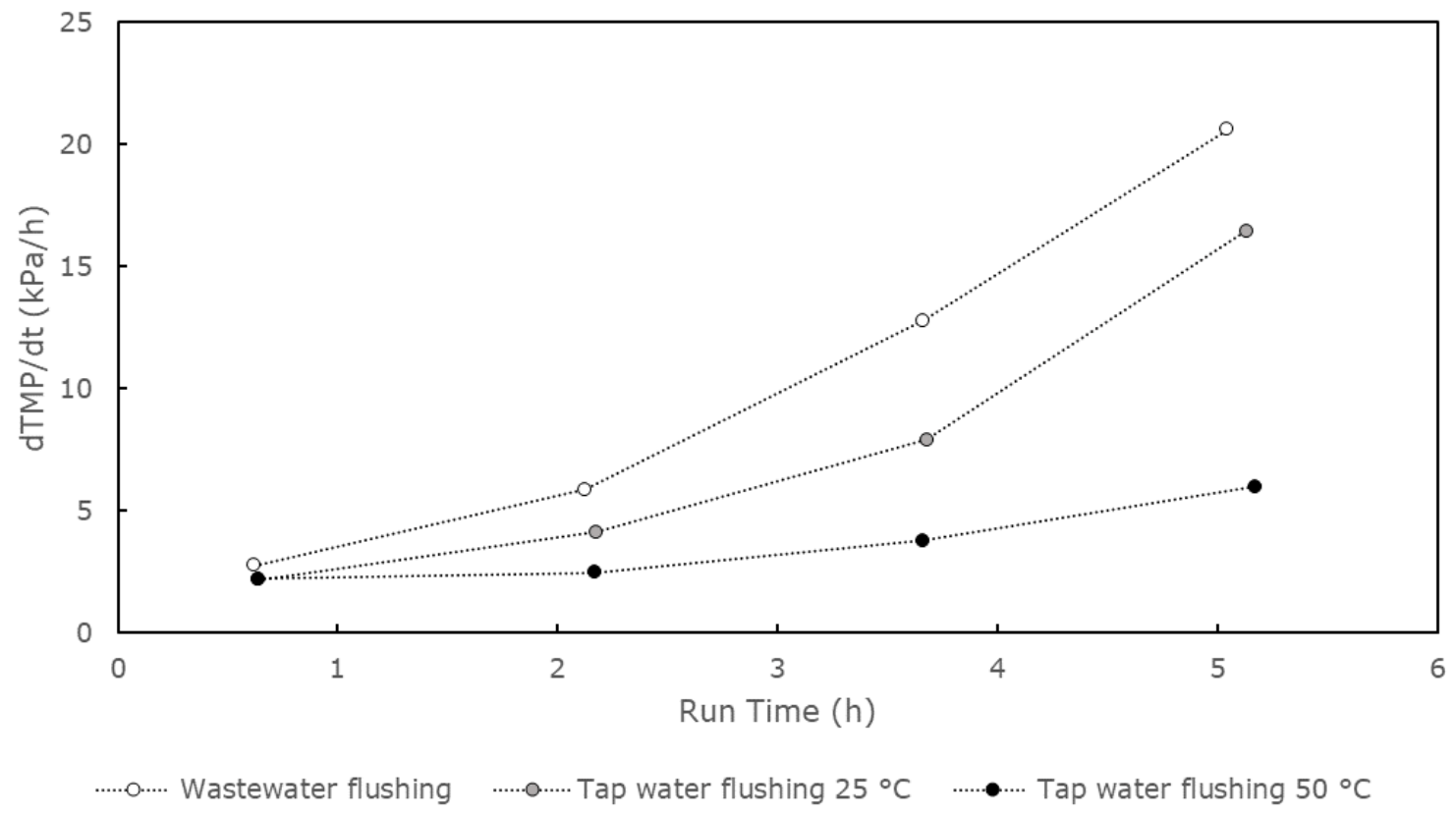

Figure 18. Membrane fouling rate $(d T M P / d t)$ at varying temperatures during intermittent filtration with tap water flushing $(0.1 \mathrm{~m} / \mathrm{s})$. 


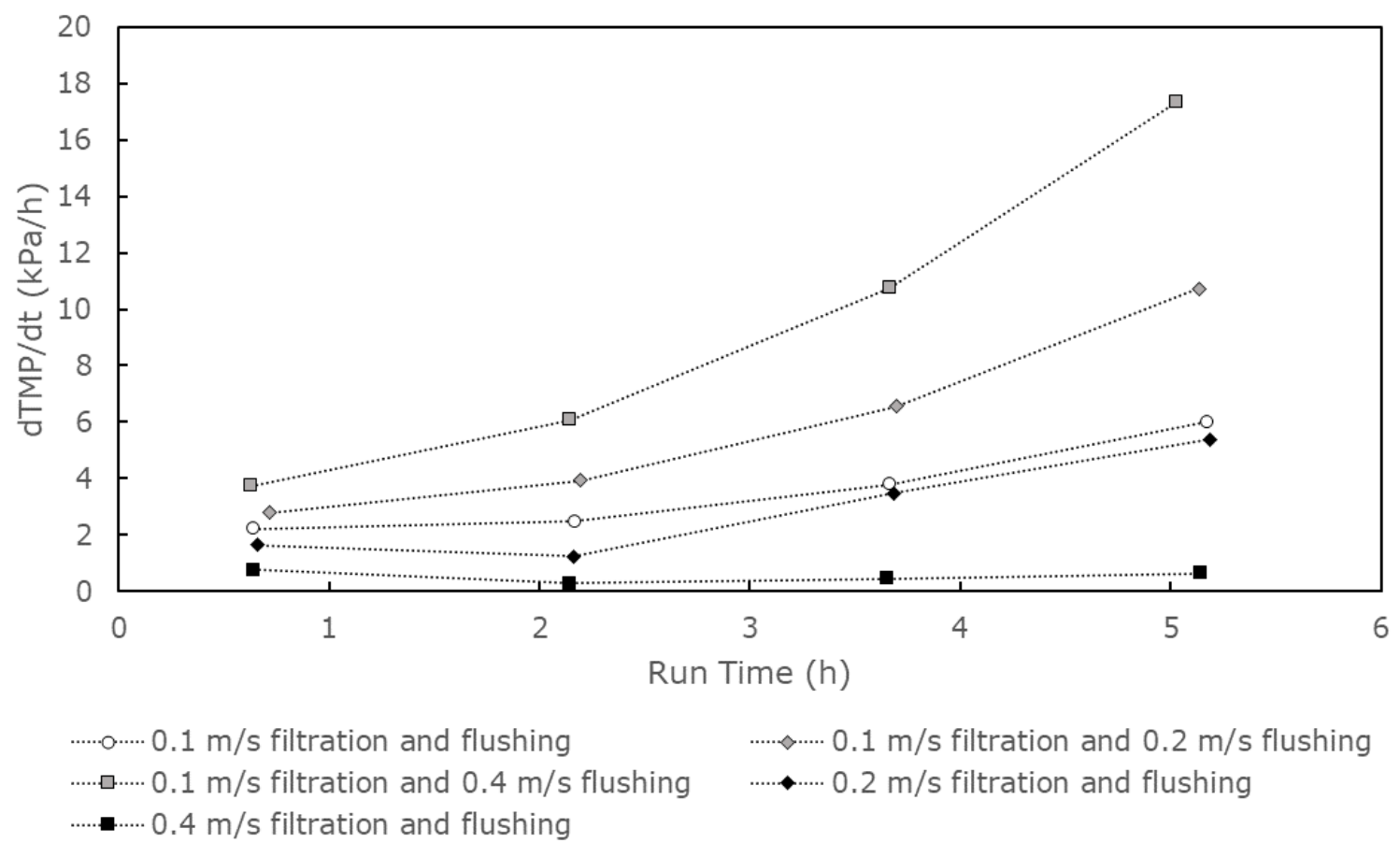

Figure 19. Membrane fouling rate (dTMP/dt) at varying filtration and flushing flow velocities $\left(50{ }^{\circ} \mathrm{C}\right.$ tap water $)$.

Moreover, Figure 20 shows the resistances during intermittent filtration at $0.1 \mathrm{~m} / \mathrm{s}$ with different flushing waters. The cake layer resistances of the filtrations with cold and heated tap water flushing were lower than during the filtration with wastewater flushing $\left(3.5^{*} 10^{11}\right.$, $5.35^{*} 10^{11}$ and $6.0^{*} 10^{11} 1 / \mathrm{m}$ respectively). Starting from a similar value, the increase during the filtrations with tap water flushing were significantly lower than during wastewater flushing. The irreversible and irremovable resistances during filtration with cold tap water flushing were very similar to those during filtration with wastewater flushing $\left(6.2^{*} 10^{11}\right.$ and $6.9^{*} 10^{11} 1 / \mathrm{m}$ respectively). However, the irreversible and irremovable resistances during filtration with heated tap water flushing were significantly lower $\left(2.38 * 10^{11} 1 / \mathrm{m}\right)$. This could be attributed to the increased solubility of foulants in higher temperatures. The heated tap water flushing was thus effective for prevention of irreversible and irremovable fouling, while the mechanical effect for cake layer removal was similar to the flushing with cold tap water. In long-term filtration the control of irreversible and irremovable fouling is crucial (Crittenden et al., 2012), therefore heated tap water flushing is a promising method to achieve stable long-term operation. 
a)

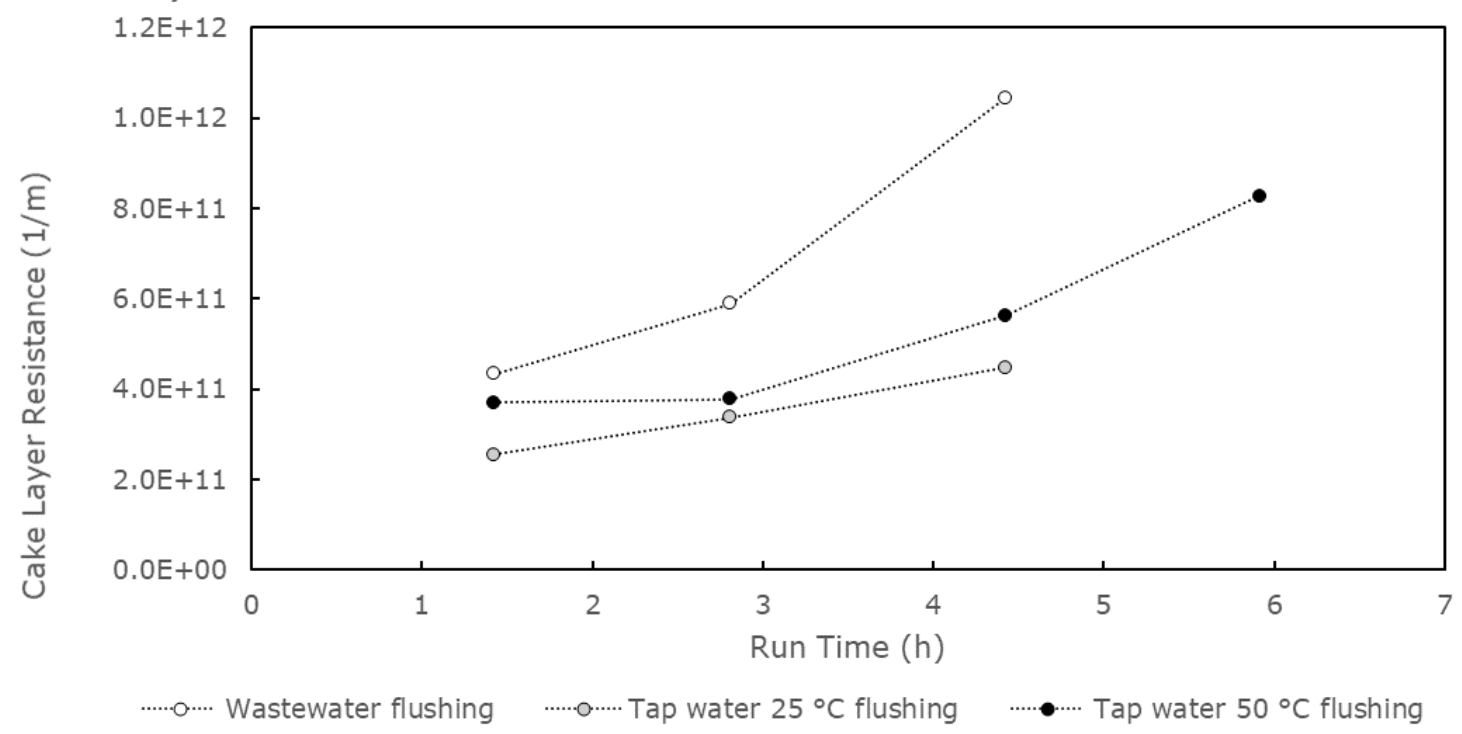

b)

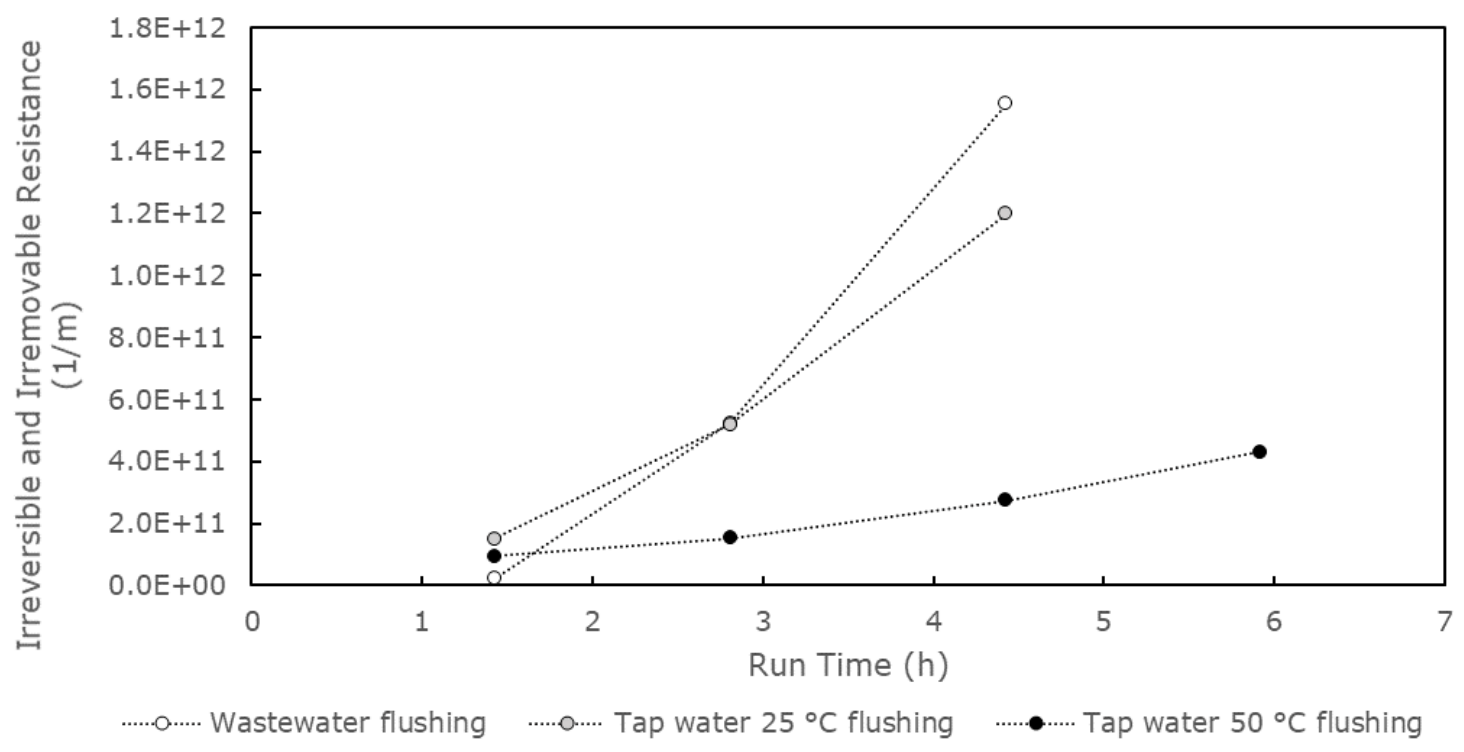

Figure 20. Cake layer (a) and irreversible and irremovable (b) resistance at varying temperatures during intermittent filtration with tap water flushing $(0.1 \mathrm{~m} / \mathrm{s})$.

Figure 21 shows the resistances during intermittent crossflow filtrations with hot tap water flushing at different flow and flushing velocities. The resistances of the filtration where the flow velocity was only increased during flushing (mean, cake layer: $6.85^{*} 10^{11}$ and $8.4^{*} 10^{11}$ $1 / \mathrm{m}$; mean irreversible and irremovable: $4.68 * 10^{11}$ and $5.5^{*} 10^{11} 1 / \mathrm{m}$ ) were clearly higher than during filtration with constant flow velocity (mean cake layer: $5.35^{*} 10^{11}, 3.23^{*} 10^{11}$ and $1.12 * 10^{11} \mathrm{1} / \mathrm{m}$; mean irreversible and irremovable: $2.38^{*} 10^{11}, 1.86^{*} 10^{11}$ and $0.001 / \mathrm{m}$ ). Especially the irremovable and irreversible resistances showed steep increases when the flow velocity was only increased during flushing. The increase of the cake layer resistances was similar throughout all filtrations, but the starting value was lower for the ones with a constant flow velocity through filtration and flushing. The constant $0.4 \mathrm{~m} / \mathrm{s}$ filtration did not show 
any increase in the cake layer resistance and all irremovable and irreversible fouling values were zero. These observations implied that by increasing the flow velocity only during flushing, the cake layer was compressed and tightly attached foulants shifted to irreversible fouling.

a)

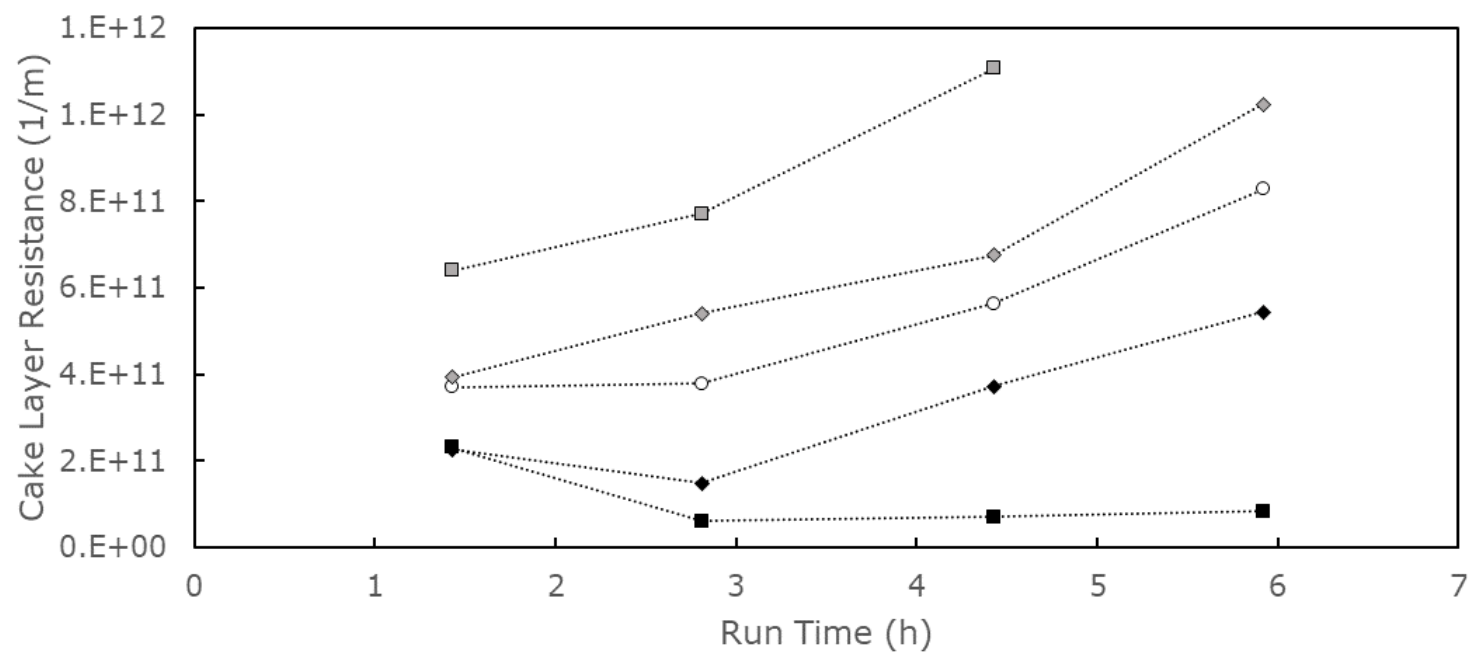

$\cdots \cdots . . \cdots \cdots . .0 .1 \mathrm{~m} / \mathrm{s}$ flushing and filtration $\quad \cdots \cdots \cdots \cdots . .0 .1 \mathrm{~m} / \mathrm{s}$ filtration and $0.2 \mathrm{~m} / \mathrm{s}$ flushing $\cdots \cdots \cdots \cdots .0 .1 \mathrm{~m} / \mathrm{s}$ filtration and $0.4 \mathrm{~m} / \mathrm{s}$ flushing $\cdots \cdots \cdots \cdot 0.2 \mathrm{~m} / \mathrm{s}$ filtration and flushing .......... $0.4 \mathrm{~m} / \mathrm{s}$ filtration and flushing

b)

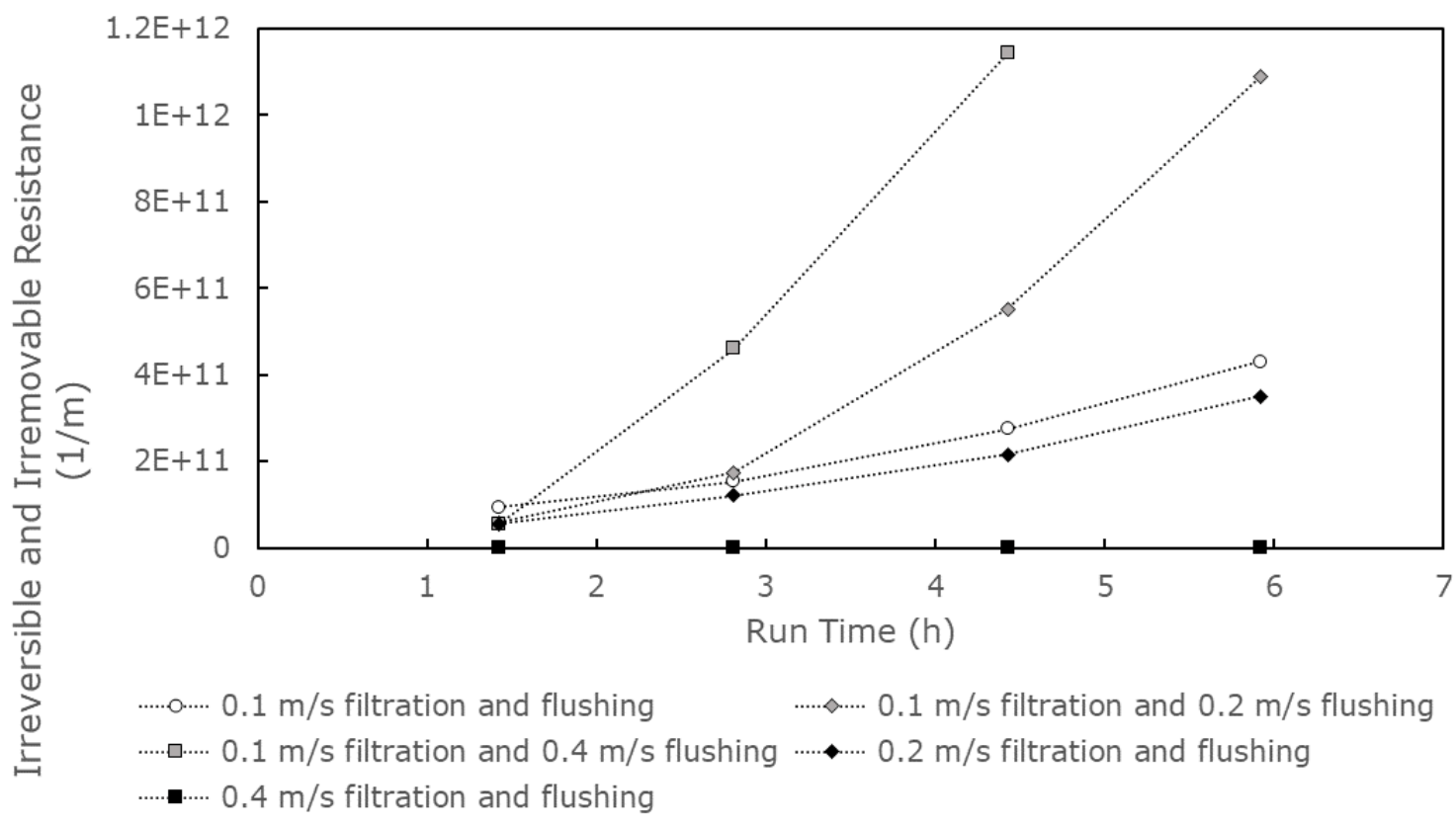

Figure 21. Cake layer (a) and irreversible and irremovable (b) fouling resistances at $1.25 \mathrm{~h}$ filtration interval and varying filtration and flushing flow velocities (rates with $50{ }^{\circ} \mathrm{C}$ tap water). 


\section{Filtration/ Flushing frequency}

Subsequently, the filtration interval time was further extended during filtration velocity at $0.4 \mathrm{~m} / \mathrm{s}$ with heated tap water flushing. The dTMP/dt data for three of the longer-term filtrations were shown in Figure 22 and the averaged data were summarized in Table 5.

The dTMP/dt values were very low, compared to previous results: for the shorter filtrations $(<10 \mathrm{~h})$ values stayed mostly below $1 \mathrm{kPa} / \mathrm{h}$. Moreover, the shorter filtration intervals led to slightly lower dTMP/dt values, but the increase of the dTMP/dt throughout the filtration cycles was similar to the longer filtration intervals. However, during longer filtration, the $\mathrm{dTMP} / \mathrm{dt}$ increased but the average remained under $10 \mathrm{kPa} / \mathrm{h}$, which was lower than in previous filtrations.

Accordingly, the filtration interval only greatly influenced the filtration performance, when the differences in the intervals were great. The data of the filtrations with intervals between 1 and $2 \mathrm{~h}$ did not differ greatly. The differences in the shorter filtrations were also only minimal. As shorter intervals allowed a longer filtration, their positive effect was confirmed. More in some cases the TMP dropped below the initial TMP after a flushing cycle. This could indicate that the membrane characteristics were altered during this operation at high flow velocity. It was noted, that the dTMP/dt stayed nearly constant during the first 6 to $8 \mathrm{~h}$ of filtration with shorter filtration intervals (Figure 22) after which, the dTMP/dt increased constantly. This could be attributed to the accumulation and compression of foulants on the membrane in longer operation. More, the filtrations with a shorter filtration interval could be run for longer. However, towards the end of the filtrations the dTMP/dt was much higher than the one at the end of the filtrations with a longer filtration interval. Even with regular flushing of the membrane, the initial TMP could not be restored after some hours into the filtration. This indicated that the physical cleaning was not sufficient. 


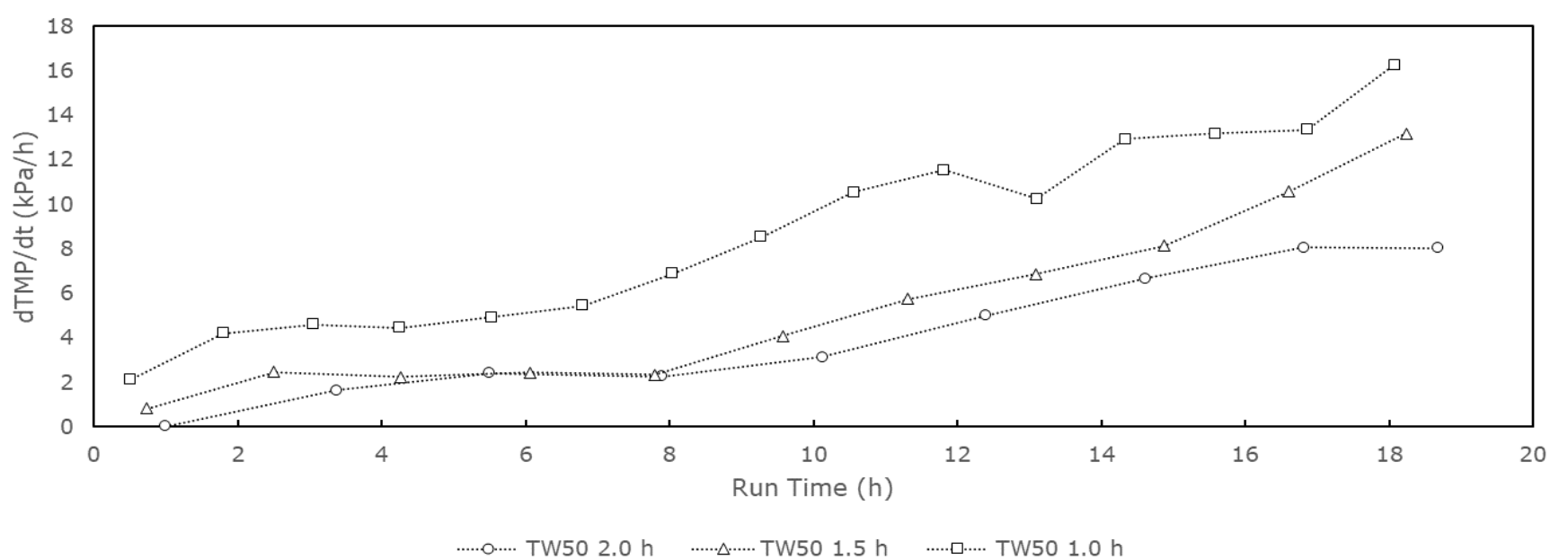

Figure 22. Membrane fouling rate (dTMP/dt) during intermittent filtration with heated tap water flushing 
Table 5. Membrane fouling rate (dTMP/dt) and resistance values during intermittent filtration with heated tap water flushing

\begin{tabular}{ccccc}
\hline $\begin{array}{c}\text { Intermittent } \\
\text { frequency }\end{array}$ & $\begin{array}{c}\text { Filtration } \\
\text { cycles }\end{array}$ & $\begin{array}{c}\text { Averaged } \\
\mathrm{dTMP} / \mathrm{dt}\end{array}$ & $\begin{array}{c}\text { Cake } \\
\text { layer } \\
\text { resistance }\end{array}$ & $\begin{array}{c}\text { Irreversible } \\
\text { and } \\
\text { irremovable } \\
\text { resistance }\end{array}$ \\
\hline $\mathrm{h}$ & & $\mathrm{kPa} / \mathrm{h}$ & $\times 10^{11} / \mathrm{m}$ & $\times 10^{11} / \mathrm{m}$ \\
\hline 1.25 & 4 & 0.54 & 1.12 & 0.00 \\
2.0 & 3 & 0.46 & 1.74 & 0.00 \\
4.0 & 2 & 0.74 & 4.86 & 0.20 \\
5.5 & 1 & 1.01 & 8.26 & 0.31 \\
1.0 & 15 & 8.61 & 8.83 & 7.00 \\
1.5 & 11 & 5.35 & 7.24 & 3.34 \\
2.0 & 9 & 4.13 & 6.86 & 5.05 \\
4.0 & 4 & 3.57 & 9.34 & 7.32 \\
6.0 & 3 & 3.35 & 13.92 & 4.96 \\
\hline
\end{tabular}

Based on the experimental results shown in Table 5, cake layer fouling resistance and irreversible and irremovable fouling resistance appeared to increase with extending filtration cycles. During the shorter filtration period (up to 4 filtrations cycles), irreversible and irremovable resistance was close to zero, thus cake layer resistance was dominant. However, with extending filtration cycles, the cake layer fouling resistance and irreversible and irremovable resistance were comparable. This was caused by the steep increase of irreversible and irremovable resistance after 8 to $10 \mathrm{~h}$ of filtration (Figure 23), which correlated with the dTMP/dt increase. This suggested that under current operation conditions, fouling could be only mostly controlled during the first 8-10 h of operation. This could be attributed to the accumulation of foulants and compression of the cake layer during longer filtration. This indicated that a long-term operation needed additional measures as intermittent heated tap water flushing and an increased flow velocity did not mitigate fouling. 

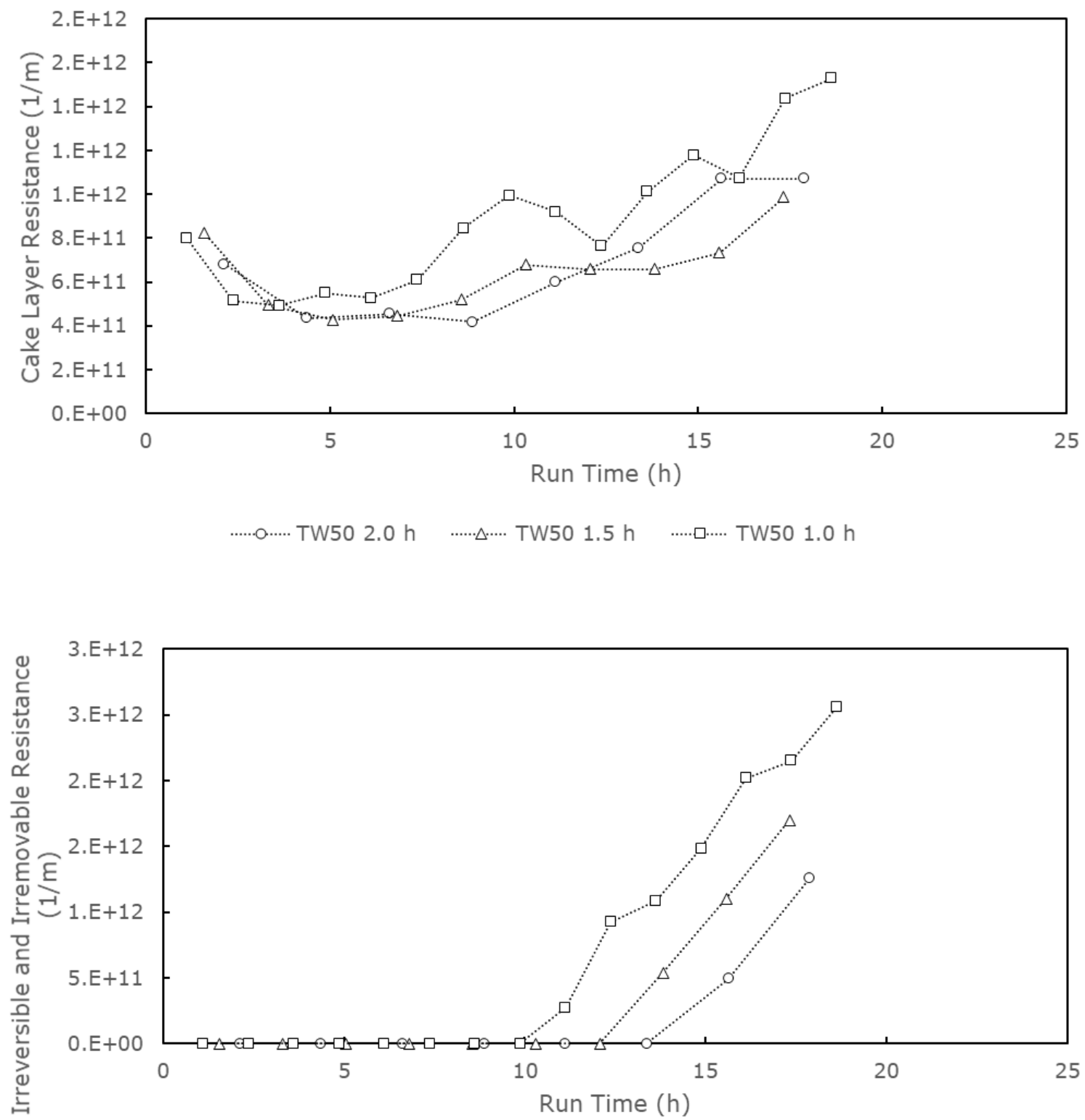

............ TW50 $2.0 \mathrm{~h} \quad$.............TW50 $1.5 \mathrm{~h} \quad$........... TW50 $1.0 \mathrm{~h}$

Figure 23. Resistances during intermittent filtration with heated tap water

\subsubsection{Direct Observation of Fouling via OCT}

The OCT scans taken during the filtration and cleaning processes at $8 \mathrm{kPa}$ and $50 \mathrm{kPa}$ feed pressure are presented in Figure 24 and Figure 25 respectively. The red lines were manually added to emphasize the position of the membrane surface. The thickness data is further shown in Figure 26. 

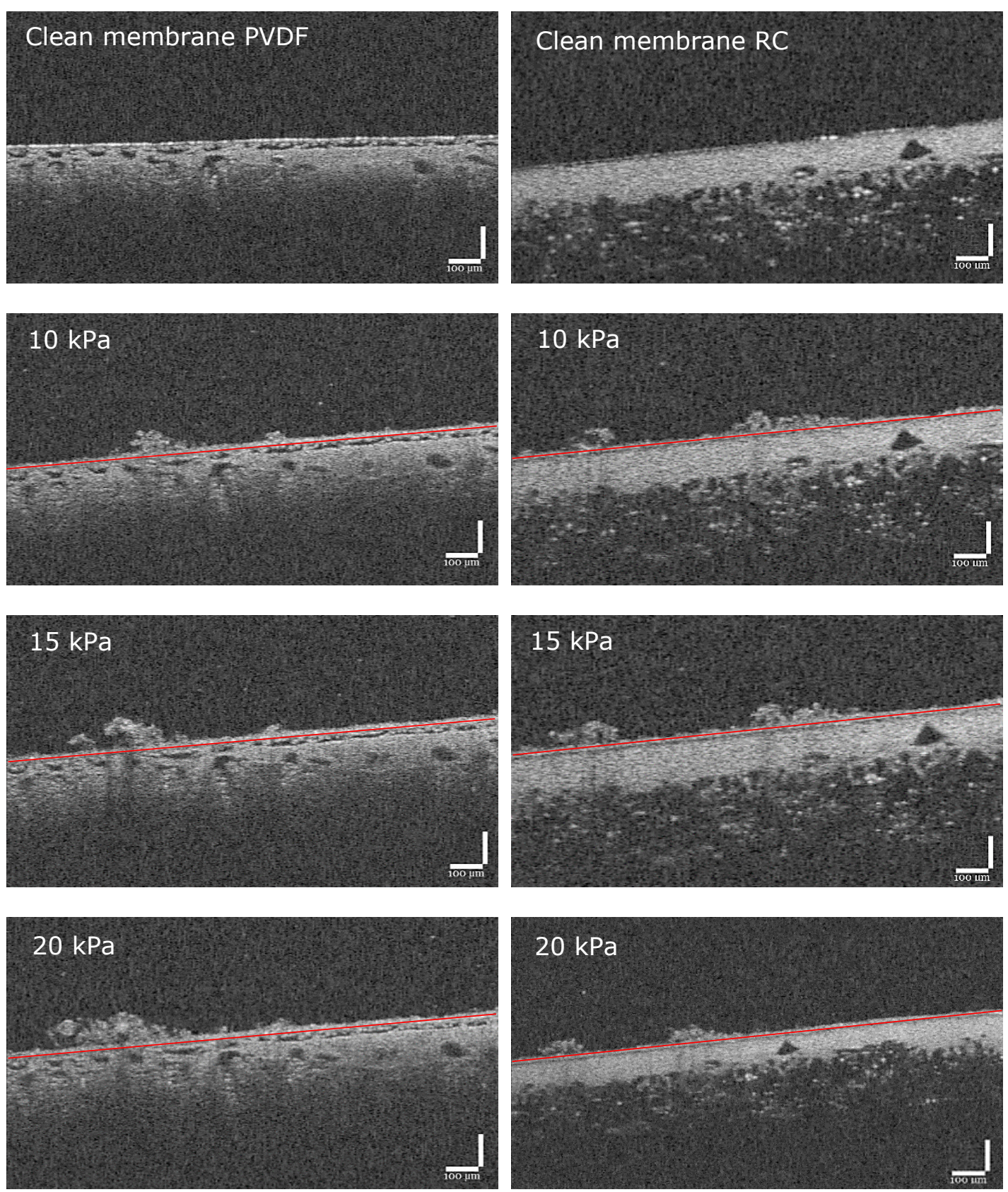

\section{$20 \mathrm{kPa}$}
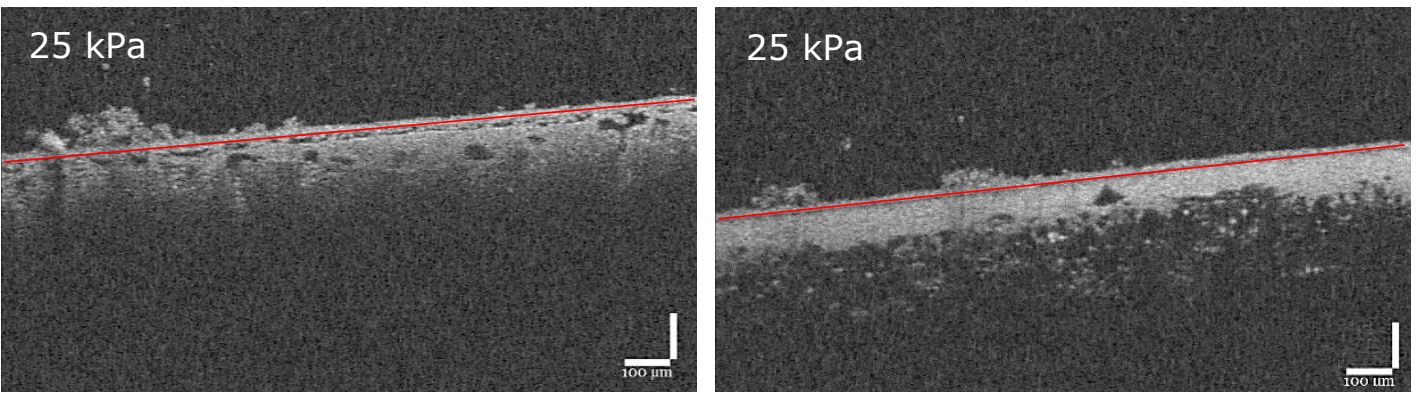

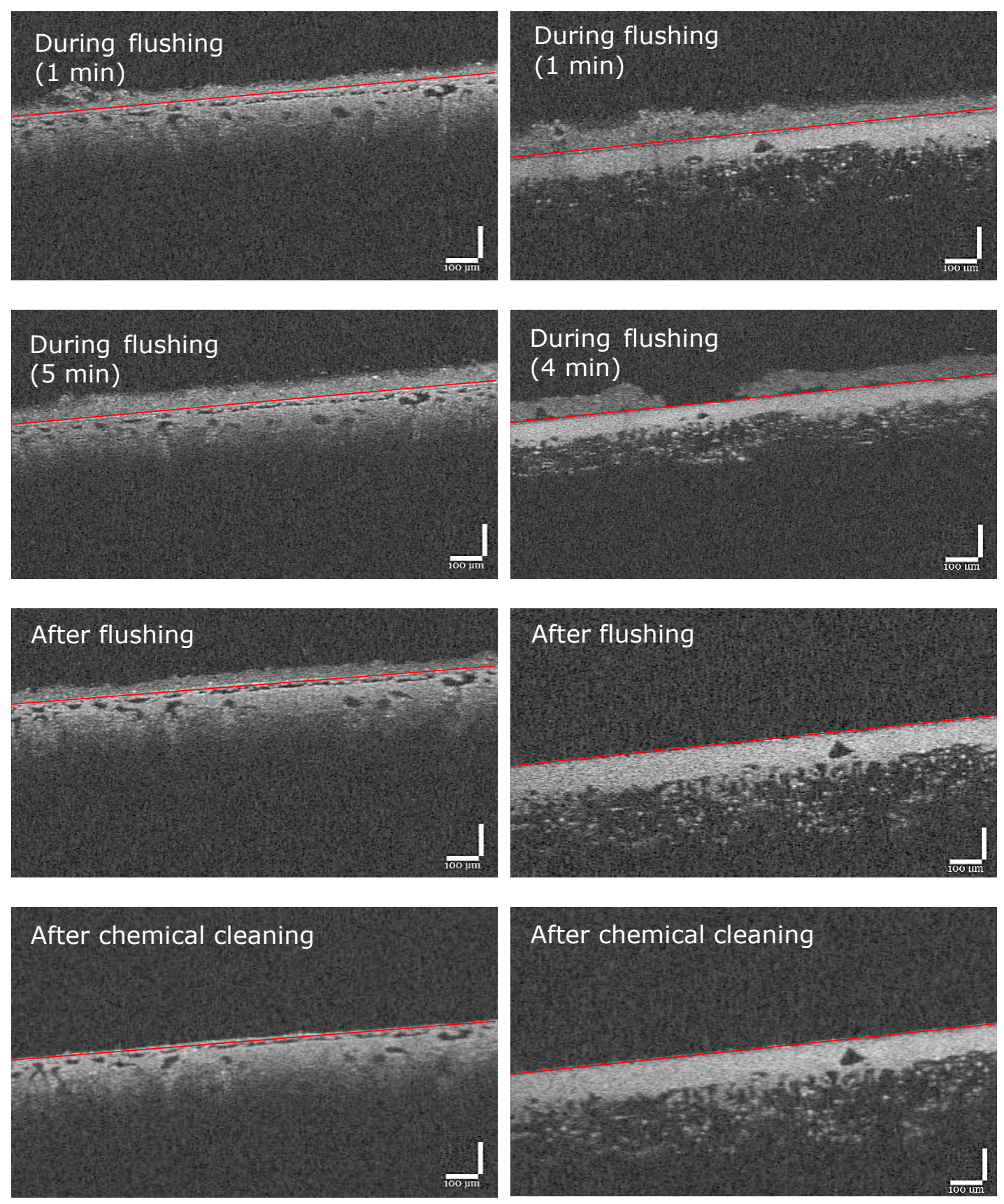

Figure 24. OCT images of the cake layer evolution - PVDF (left) and RC (right) at $8 \mathrm{kPa}$ feed pressure, $0.1 \mathrm{~m} / \mathrm{s}$ filtration, clean water flushing and chemical cleaning with $0.5 \%$ $\mathrm{NaOCl}$. 

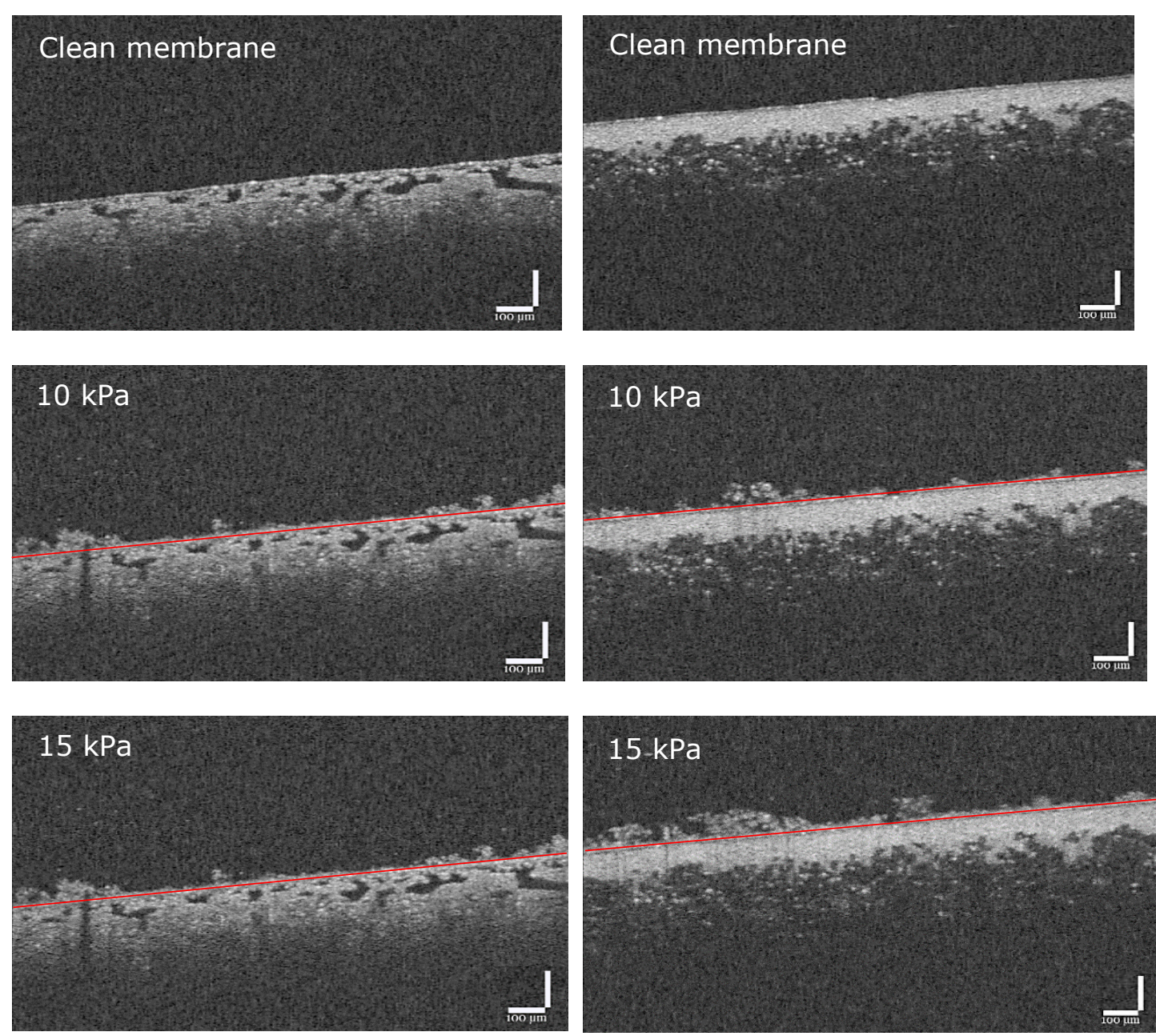

$15-\mathrm{kPa}$

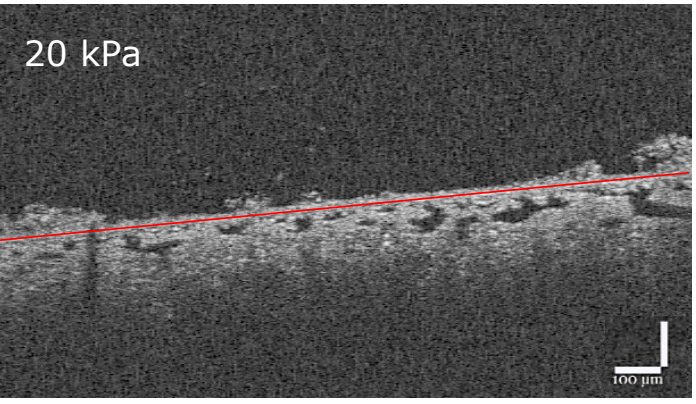

$20 \mathrm{kPa}$

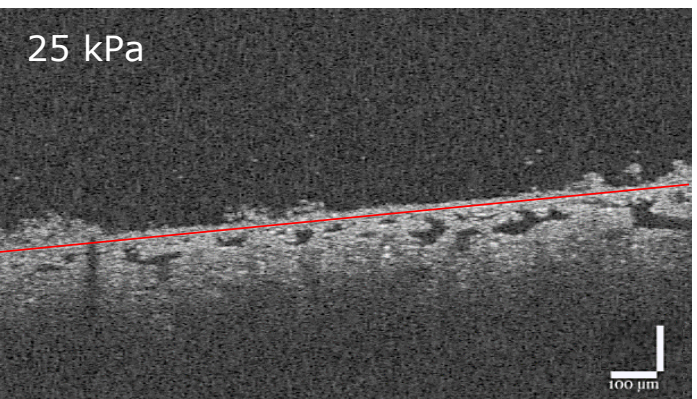

$25 \mathrm{kPa}$

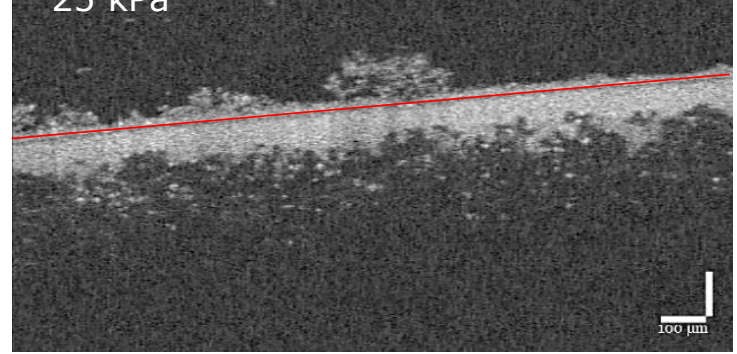



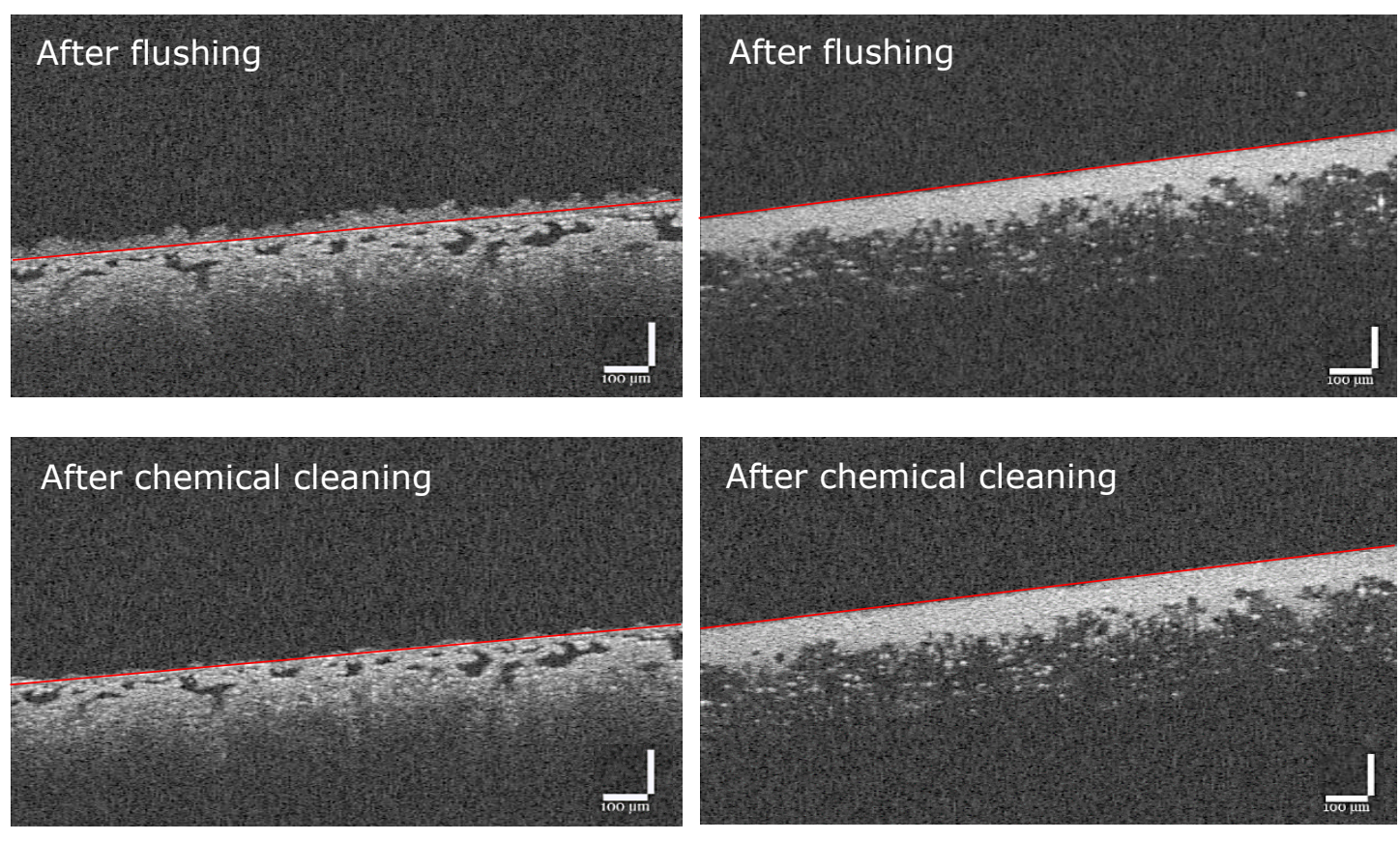

Figure 25. OCT images of the cake layer evolution - PVDF (left) and RC (right) at $50 \mathrm{kPa}$ feed pressure, $0.1 \mathrm{~m} / \mathrm{s}$ filtration, clean water flushing and chemical cleaning with $0.5 \%$ $\mathrm{NaOCl}$.

As shown in the Figure 26, the building up of the cake layer followed the same pattern for all conducted filtrations. When the TMP reached $10 \mathrm{kPa}$, a thin cake layer could be seen with some additional small mushroom-like depositions. With the increase of the TMP, the cake layer did not grow significantly. Instead the number and size of mushroom-like depositions increased. This suggested that the density of the cake layer increased. Concerning the RC membrane, the cake layer kept growing slightly until a TMP of $20 \mathrm{kPa}$ was reached. In this case, the cake layer density and thickness both increased, which corresponded to an increase of TMP. The evolution of the cake layer on the RC membranes was very similar at the two different feed pressures. However, the PVDF filtration showed a slight trend: the $50 \mathrm{kPa}$ feed pressure filtration created a thicker cake layer, than the $8 \mathrm{kPa}$ feed pressure filtration. The evolution however was similar after the initial divergence. 

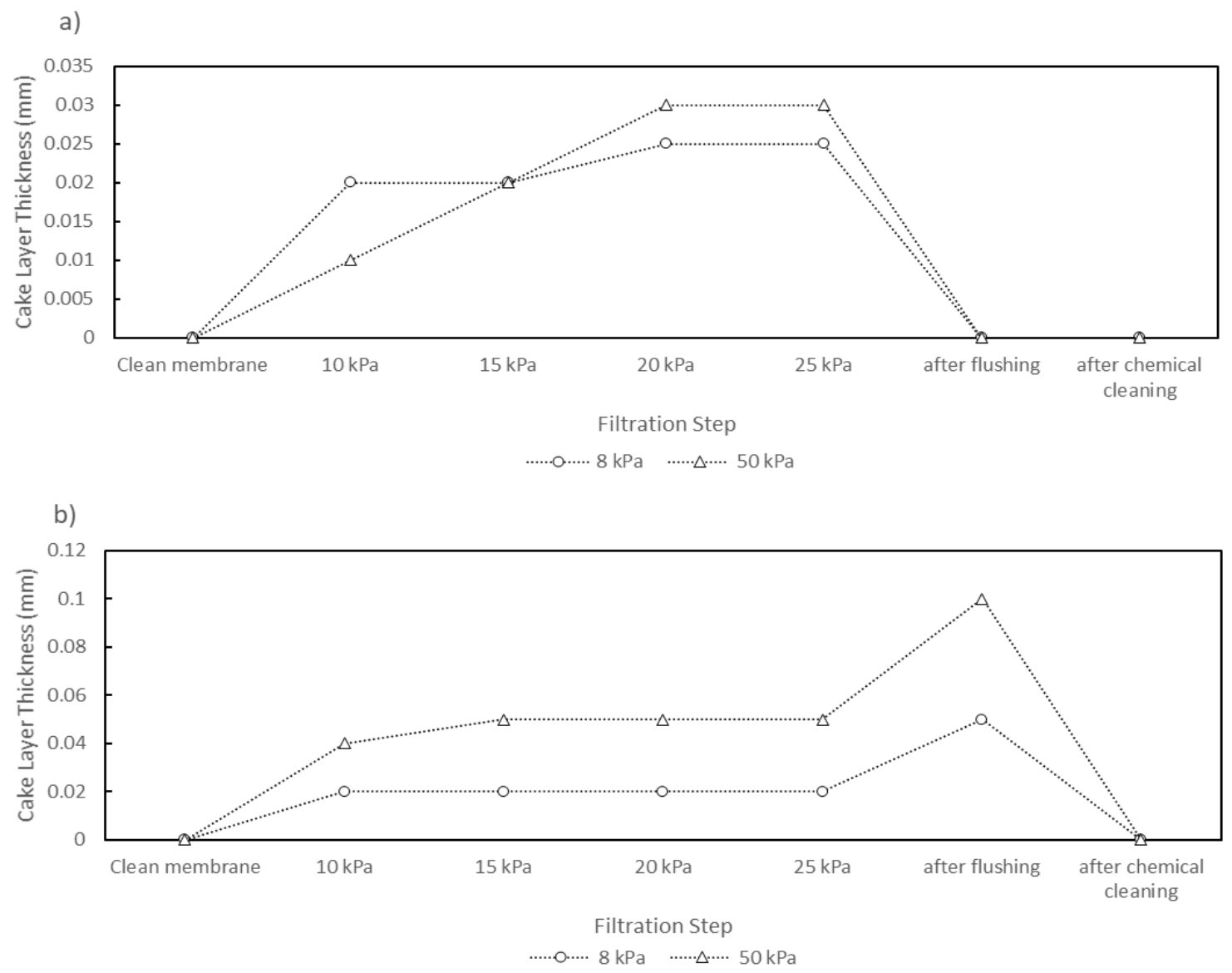

Figure 26. Cake layer thickness during filtration with $R C(a)$ and PVDF (b) membrane

During flushing, the cake layer on the RC membrane got thicker for some seconds before it was washed away. However, the flushing did not lead to a cake layer detachment from the PVDF membranes. The thickness after the flushing was greater than that before starting it, but slightly less than that during flushing. It is noted that distilled water was used for the flushing, therefore no new depositions from the flushing water contributed to the increased cake layer thickness. Indeed, during the flushing, the permeate flux was stopped. Thus, the foulants were less driven towards and into the membrane. This indicated, that only loosely attached foulants were washed away while tightly attached foulants stayed on the membrane. The flushing turned foulants considered as irreversible fouling into cake layer fouling. During flushing of the RC membrane, the cake layer detached quickly, while it did not detach from the PVDF membrane. This could be attributed to the different pore sizes. In this case the pore size of the RC membrane $(100 \mathrm{kDa})$ was smaller than the PVDF membrane $(0.08 \mu \mathrm{m})$. Foulants could penetrate the larger pores from where they were washed out again during flushing. As fewer foulants penetrated the RC membrane, the phenomenon was less apparent and the cake layer more loosely attached.

When taking the filtration resistance data into account, even though a cake layer was visible on the PVDF membrane after the flushing, it did not contribute greatly to the filtration resistance. This suggested that the fouling resistance depends on the morphology of the cake layer, in this case, it could be assumed that it had a high porosity and thus did not create 
significant resistance. However, in longer filtration these converted foulants could be compressed during the following filtration step and thus contributed to the increases of resistance and TMP.

To investigate the cake layer behavior during flushing, the $50 \mathrm{kPa}$ feed pressure filtration was repeated and the flow velocity was changed during flushing. The corresponding scans are shown in Figure 27.
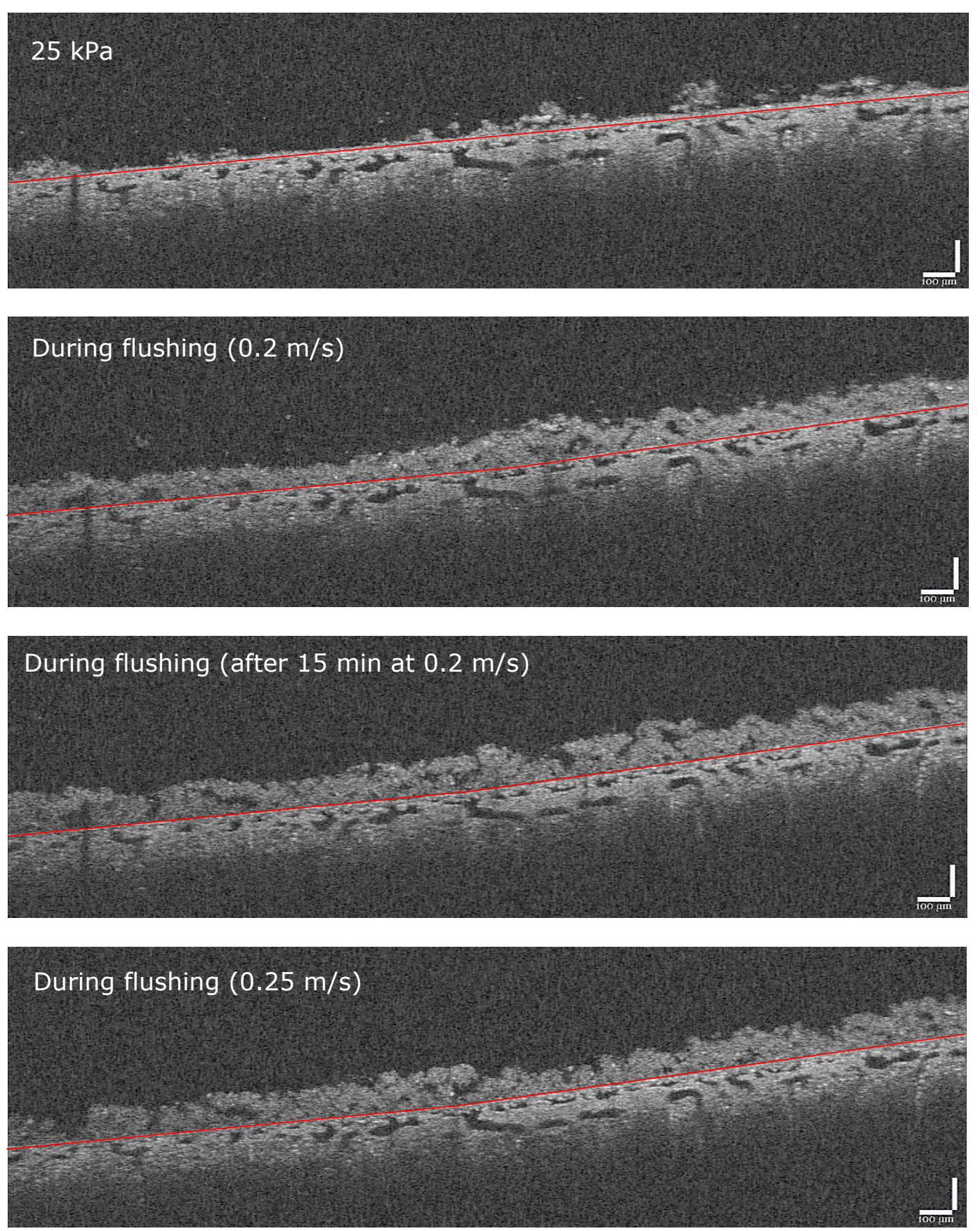

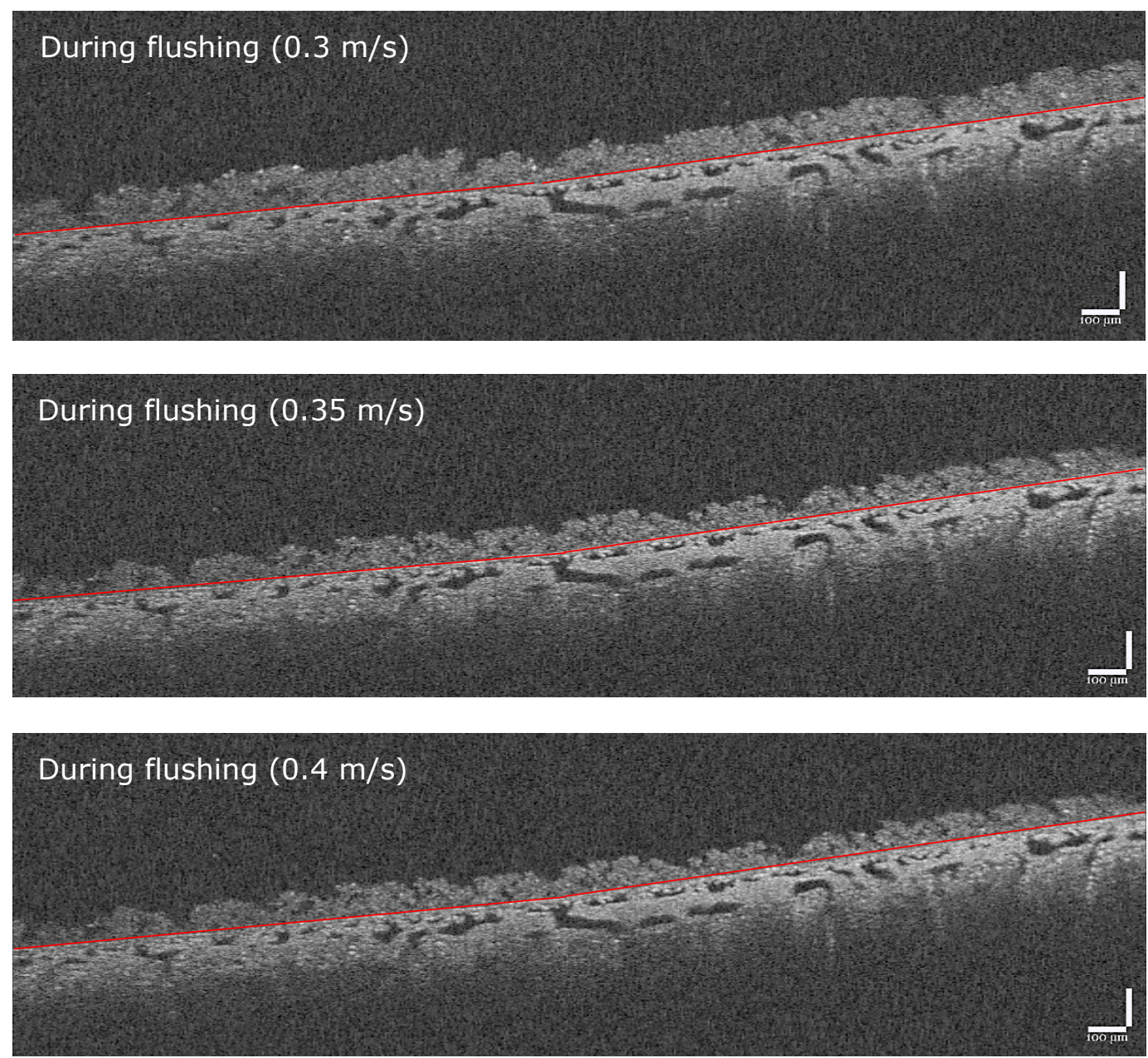

During flushing (after relaxation from 0.4 to 0.1 to $0.4 \mathrm{~m} / \mathrm{s}$ )
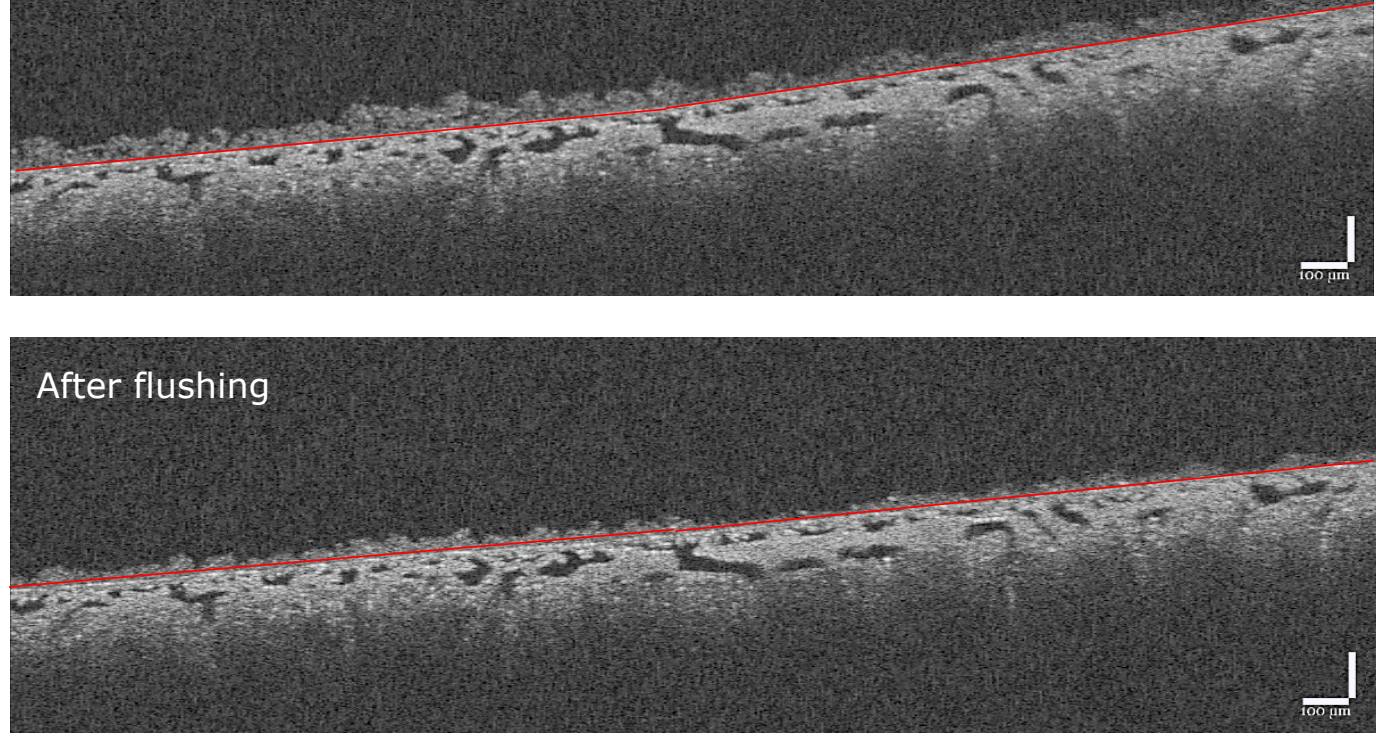

Figure 27. Cake layer evolution during clean water at varying flow velocities flushing of the PVDF membrane after filtration at $50 \mathrm{kPa}$ feed pressure and $0.1 \mathrm{~m} / \mathrm{s}$ flow velocity. 
The increase of the flow velocity during flushing only had little effect on the cake layer thickness. At the beginning of each increase step, the thickness reduced slightly, but after 5 more minutes of flushing, no more changes could be detected. At a flow velocity of $0.4 \mathrm{~m} / \mathrm{s}$, a feed pressure of $25 \mathrm{kPa}$ was reached. In order to relax the membrane during the flushing, it was tested to reduce the flow velocity back to $0.1 \mathrm{~m} / \mathrm{s}$ before increasing it to $0.4 \mathrm{~m} / \mathrm{s}$ again. This also slightly reduced the cake layer but failed to remove it as efficiently as the flushing did on the RC membrane. In addition, the structure of the cake layer changed during the flushing. The cake layer thickness varied in the beginning, before some of the thicker parts were washed away. After only a few minutes, the cake layer thickness looked homogenous throughout the scanned line. These observations implied, that the tightly attached foulants can partly be removed by an increased flow velocity but failed to be removed completely. Nevertheless, an increased flow velocity could be beneficial for more stable operation, as less foulants remain on the membrane.

The averaged cake layer thicknesses of the intermittent filtrations with the PVDF membrane are shown in Table 6 . It could clearly be seen that the cake layers built up more significantly during the higher feed pressure filtration. Moreover, in average the flushing lead to an increase in the cake layer thickness. This indicated that the higher feed pressure prevented foulants from being removed by the shear during both filtration and flushing. This confirms the TMP results, as the filtration at $50 \mathrm{kPa}$ feed pressure showed steeper TMP increases, indicating that lower feed pressure was the preferred operation condition.

The filtrations with increased flow velocities as well as flushing with tap water led to an increased cake layer thickness. However, as the TMP results showed more stable operation under these conditions, it is suggested that the cake layer is less dense and thus creates less resistance. In addition, when flushing was conducted at an increased flow velocity, the total thickness was slightly lower than during constant low flow velocity and no increase in cake layer thickness during flushing could be detected. This suggested that due to the higher TMP caused by the increased flow velocity, the tightly attached foulants were compressed during flushing and only loosely attached foulants could be washed away. In contrast, when the constant increased flow velocity was coupled with hot tap water flushing, the cake layers were mostly thinner than under the previous conditions and did not show increases during flushing. This correlated with the TMP results as these conditions created the most stable operation. Moreover, for longer filtration intervals, the thickness was slightly higher than for shorter filtration intervals. Therefore, the shorter filtration intervals were proposed for further filtration experiments as the compression of remaining foulants after flushing was prevented. 
Table 6. Averaged cake layer thickness data for different operation conditions during intermittent filtration

\begin{tabular}{|c|c|c|c|c|c|c|c|}
\hline $\begin{array}{l}\text { Feed } \\
\text { press- } \\
\text { ure }\end{array}$ & $\begin{array}{c}\text { Fil- } \\
\text { tration } \\
\text { interval }\end{array}$ & $\begin{array}{l}\text { Filtration } \\
\text { crossflow } \\
\text { velocity }\end{array}$ & $\begin{array}{l}\text { Flushing } \\
\text { crossflow } \\
\text { velocity }\end{array}$ & $\begin{array}{c}\text { Flushing } \\
\text { water }\end{array}$ & $\begin{array}{l}\text { Cy- } \\
\text { cles }\end{array}$ & $\begin{array}{l}\text { Averaged } \\
\text { thickness } \\
\text { after } \\
\text { filtration }\end{array}$ & $\begin{array}{c}\text { Averaged } \\
\text { thickness } \\
\text { after } \\
\text { cleaning }\end{array}$ \\
\hline & $\mathrm{h}$ & $\mathrm{m} / \mathrm{s}$ & $\mathrm{m} / \mathrm{s}$ & & & $\mu \mathrm{m}$ & $\mu \mathrm{m}$ \\
\hline 50 & 1.75 & 0.1 & 0.1 & Wastewater & 2 & 25 & 30 \\
\hline 50 & 1.25 & 0.1 & 0.1 & Wastewater & 4 & 21 & 26 \\
\hline 8 & 1.25 & 0.1 & 0.1 & Wastewater & 4 & 8 & 5 \\
\hline 8 & 0.75 & 0.1 & 0.1 & Wastewater & 6 & 3 & 5 \\
\hline 8 & 0.5 & 0.1 & 0.1 & Wastewater & 8 & 6 & 5 \\
\hline 8 & 1.25 & 0.2 & 0.2 & Wastewater & 4 & 16 & 15 \\
\hline 30 & 1.25 & 0.4 & 0.4 & Wastewater & 3 & 10 & 10 \\
\hline 8 & 1.25 & 0.1 & 0.1 & $\begin{array}{l}\text { Tap water } \\
\left(25^{\circ} \mathrm{C}\right)\end{array}$ & 4 & 18 & 18 \\
\hline 8 & 1.25 & 0.1 & 0.1 & $\begin{array}{l}\text { Tap water } \\
\left(50^{\circ} \mathrm{C}\right)\end{array}$ & 4 & 13 & 20 \\
\hline 8 & 1.0 & 0.1 & 0.1 & $\begin{array}{l}\text { Tap water } \\
\left(50^{\circ} \mathrm{C}\right)\end{array}$ & 5 & 18 & 22 \\
\hline 8 & 1.25 & 0.1 & 0.2 & $\begin{array}{l}\text { Tap water } \\
\left(50^{\circ} \mathrm{C}\right)\end{array}$ & 4 & 13 & 13 \\
\hline 8 & 1.25 & 0.1 & 0.4 & $\begin{array}{l}\text { Tap water } \\
\left(50^{\circ} \mathrm{C}\right)\end{array}$ & 4 & 10 & 8 \\
\hline 8 & 1.25 & 0.2 & 0.2 & $\begin{array}{c}\text { Tap water } \\
\left(50^{\circ} \mathrm{C}\right)\end{array}$ & 4 & 1 & 3 \\
\hline 30 & 1.25 & 0.4 & 0.4 & $\begin{array}{l}\text { Tap water } \\
\left(50^{\circ} \mathrm{C}\right)\end{array}$ & 4 & 0 & 0 \\
\hline 30 & 2.0 & 0.4 & 0.4 & $\begin{array}{l}\text { Tap water } \\
\left(50^{\circ} \mathrm{C}\right)\end{array}$ & 3 & 5 & 5 \\
\hline 30 & 4.0 & 0.4 & 0.4 & $\begin{array}{l}\text { Tap water } \\
\left(50^{\circ} \mathrm{C}\right)\end{array}$ & 2 & 20 & 20 \\
\hline 30 & 5.5 & 0.4 & 0.4 & $\begin{array}{c}\text { Tap water } \\
\left(50^{\circ} \mathrm{C}\right)\end{array}$ & 1 & 5 & 5 \\
\hline
\end{tabular}

\subsection{Long-term Performance of DMF}

As irreversible and irremovable fouling were found to be an important factor during longerterm filtration, chemical-enhanced physical cleaning was implemented with periodical physical cleaning to control membrane fouling in order to achieve sustainable DMF operation. The resulting TMP curve during 230 h-filtration is shown in Figure 28 and the corresponding dTMP/dt values in Figure 29. It is noted that between 182 and $191 \mathrm{~h}$ of filtration (in yellow), the feed pump turned off due to electricity supply issues. In consequence, there was no collected data for this interval. 
In the first five cycles, the TMP decreased to a lower level after each flushing, compared to the previous filtration cycle. This could also be seen in the first four cycles after the second and tenth chemical cleaning. In the beginning of filtrations, this phenomenon can sometimes be seen, as the membrane is new and its characteristics can change when it is first wetted. However, this is the reason why distilled water was filtrated for $30 \mathrm{~min}$ before starting the filtration with wastewater. As the decrease of the TMP can be seen throughout four to five cycles, this phenomenon could indicate an alteration of the membrane caused by high shear. When the TMP starts to increase again, a cake layer has already built up which could serve as protection for the membrane. The protecting foulants are removed during chemical cleanings and therefore the membrane is exposed again. However, after the remaining chemical cleanings the TMP increased steeper in every cycle until the next chemical cleaning or until it reached a TMP of over $25 \mathrm{kPa}$.

Moreover, the TMP increase was not always constant. For instance, it was steeper after $50 \mathrm{~h}$ but after the following two chemical cleanings, the increase was less steep again. This could be attributed to the changing feed water, which was replaced daily. Despite the feed always being diluted to $70 \mathrm{mg} / \mathrm{L}$, the composition could slightly change since it was real wastewater. In addition, the dTMP/dt stabilized after approximately $170 \mathrm{~h}$ of filtration and decreased after each chemical cleaning. This suggested an alteration of the membrane properties by the chemical cleaning with high shear velocity. When the TMP reached $25 \mathrm{kPa}$, the increase stopped. During these periods, the permeate flux also decreased because the driving force was not strong enough to maintain it. The TMP could be restored by chemical cleanings, which indicated that no irremovable fouling accumulated. The main finding from the longterm run was that chemical cleaning was the key factor to control the TMP in long-term operation, which corresponds to results from previous DMF studies (Kimura et al., 2017; Lateef et al., 2013). The observation clearly implied how efficiently the chemical cleaning reduces made long-term operation possible. 


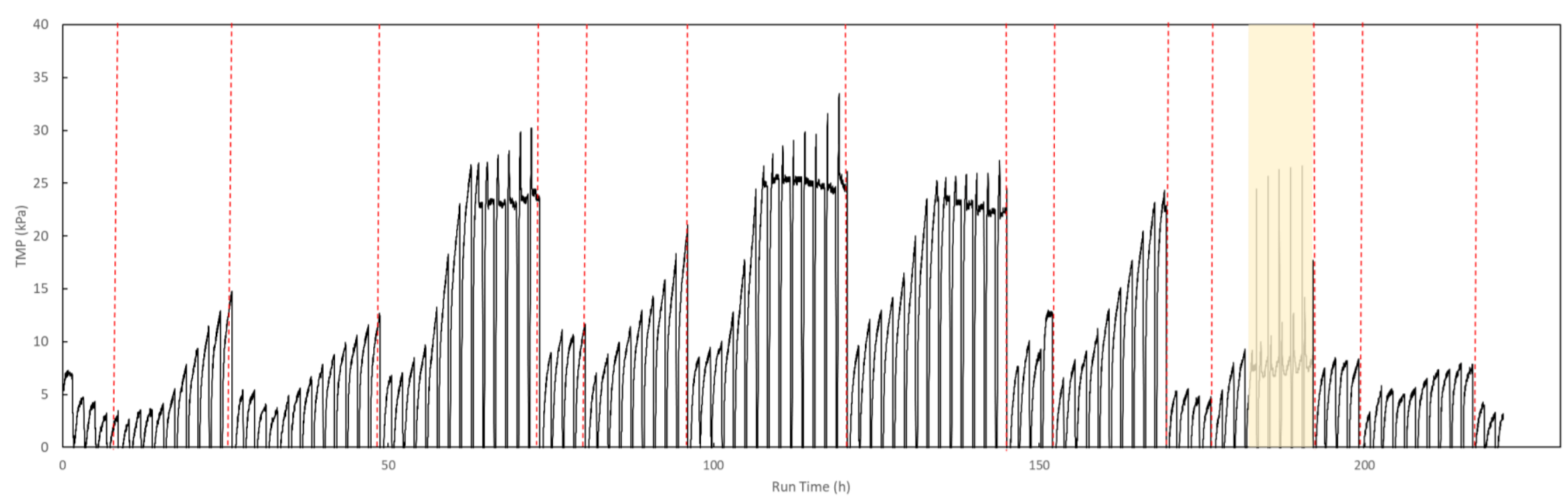

Figure 28. TMP curve during intermittent long-term filtration with heated tap water flushing and chemical cleanings (red lines)

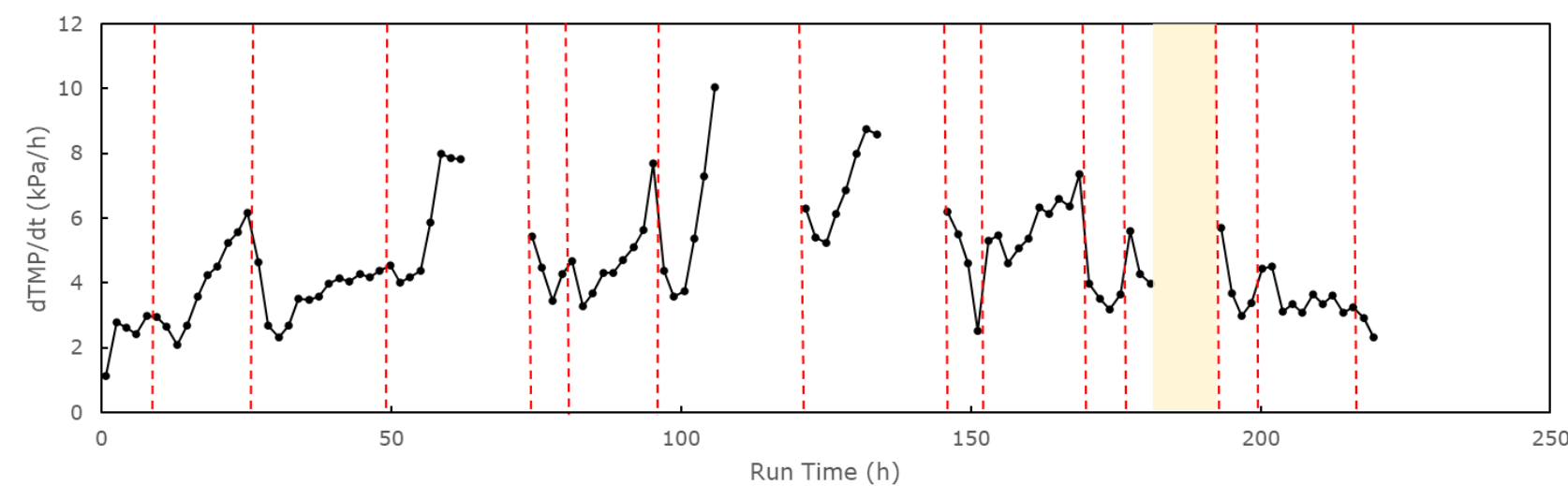

Figure 29. dTMP/dt during long-term intermittent filtration with heated tap water flushing and chemical cleanings (red lines) 


\subsection{Water Quality and Foulants Analysis}

\subsubsection{Permeate Water Quality}

As shown in the Section 4.2 and 4.3, the PVDF membrane $(0.08 \mu \mathrm{m})$ showed better membrane performance during DMF of wastewater. Therefore, the permeate samples were taken from the filtration experiments using the PVDF membranes $(0.08 \mu \mathrm{m})$ which have been presented in the previous sections ( 4.2 and 4.3). Table 7 summarizes the detailed compositions of soluble organics and inorganics of the feed and permeate wastewater, which were examined by various analytical methods and presented as averaged data of multisamples taken during the experimental period (feed sampling number and permeate sampling number each $n=16$ ). In detail, the feed wastewater contained solids at $15.06 \pm 5.74 \mathrm{mg} / \mathrm{L}$. The permeate water in the tested DMF experiments was almost turbidity-free due to excellent rejection of the PVDF membrane $(0.08 \mu \mathrm{m})$.

In the feed wastewater, the major soluble organics were building blocks (measured by LCOCD analysis, $39 \pm 5 \%$ ) and humic acid-like substances (measured by EEM analysis, $38 \pm 2 \%$ ); the major soluble inorganics were $\mathrm{Cl}, \mathrm{SO}_{4}, \mathrm{Na}, \mathrm{Ca}$ elements. While, in the permeate water, the major soluble organics were also building blocks (measured by LCOCD analysis, $37 \pm 13 \%$ ) and humic acid-like substances (measured by EEM analysis, $38 \pm 5 \%$ ); the major soluble inorganics were $\mathrm{Cl}, \mathrm{SO}_{4}, \mathrm{Na}$, Ca elements.

Furthermore, the permeate water quality was compared with the feed water quality in order to examine the removal efficiency of wastewater components. To illustrate statistical significance, a two-sample T-test was performed by comparing the sampling data groups for the feed and permeate water. The $p$-value for the two-sample T-test was calculated at a significance level at 5\%. As shown in Table 6 , the following components have been significantly removed from the feed water ( $p$-value <0.05): TSS (100\% removal), Biopolymers (61.5\% removal) and Protein-I like substances (16.8\% removal). While, almost insignificant removal for other components, such as Building blocks, Protein II-like substances, soluble microbial-by-product like substances, fulvic acid-like substances, humic acid-like substances, $\mathrm{F}, \mathrm{Cl}, \mathrm{NO}_{2}, \mathrm{NO}_{3}, \mathrm{PO}_{4}, \mathrm{SO}_{4}, \mathrm{Na}, \mathrm{Mg}$ and $\mathrm{Ca}$. In contrast, the concentrations of LMW neutrals and acids in the permeate were significantly higher than those in the feed (by 64 and $110 \%$ respectively). This could be attributed to the decomposition of building blocks, which are greater in size, into low molecular weight components. The tested inorganic ions were not significantly removed, which could be attributed to the greater pore size of MF membranes (not rejecting ions) (Singh and Hankins, 2016). Last, the difference in humic substances in the results measured by EEM and LCOCD could be explained by the different sample preparing filters. The analysis by LC-OCD involved a filtering by a $0.22 \mu \mathrm{m}$ filter while the samples for the EEM were filtered through a $0.45 \mu \mathrm{m}$ filter. 
Table 7. Feed and permeate water characteristics

\begin{tabular}{|c|c|c|c|c|c|c|}
\hline $\begin{array}{l}\text { Measurement } \\
\text { method }\end{array}$ & Parameter & Unit & $\begin{array}{c}\text { Feed } \\
\text { wastewater } \\
(\mathrm{n}=16)\end{array}$ & $\begin{array}{l}\text { Permeate water } \\
\quad(\mathrm{n}=16)\end{array}$ & $\begin{array}{c}p \text { - } \\
\text { value }\end{array}$ & $\begin{array}{l}\text { Remo- } \\
\text { val ratio } \\
(\%)\end{array}$ \\
\hline & TSS & $\mathrm{mg} / \mathrm{L}$ & $15.06 \pm 5.74$ & $0.00 \pm 0.00$ & 0.00 & 100 \\
\hline $\begin{array}{l}\text { TOC (filtered } \\
\text { through } 0.45 \mu \mathrm{m} \text { ) }\end{array}$ & DOC & $\mathrm{mg} / \mathrm{L}$ & $10.88 \pm 2.89$ & $13.45 \pm 4.53$ & 0.08 & 0 \\
\hline \multirow{5}{*}{$\begin{array}{l}\text { LC-OCD (filtered } \\
\text { through } 0.22 \mu \mathrm{m} \text { ) }\end{array}$} & Biopolymers & $\mathrm{mg} / \mathrm{L}$ & $1.63 \pm 0.63$ & $0.63 \pm 0.22$ & 0.00 & 61.5 \\
\hline & Humic acid & $\mathrm{mg} / \mathrm{L}$ & $0.00 \pm 0.00$ & $0.00 \pm 0.00$ & - & - \\
\hline & $\begin{array}{l}\text { Building } \\
\text { blocks }\end{array}$ & $\mathrm{mg} / \mathrm{L}$ & $4.44 \pm 0.75$ & $4.95 \pm 1.01$ & 0.13 & 0 \\
\hline & $\begin{array}{l}\text { LMW } \\
\text { Neutrals }\end{array}$ & $\mathrm{mg} / \mathrm{L}$ & $3.38 \pm 0.59$ & $5.53 \pm 3.57$ & 0.04 & 0 \\
\hline & LMW Acids & $\mathrm{mg} / \mathrm{L}$ & $0.57 \pm 0.13$ & $1.19 \pm 0.54$ & 0.00 & 0 \\
\hline \multirow{5}{*}{$\begin{array}{l}\text { EEM (filtered } \\
\text { through } 0.45 \mu \mathrm{m} \text { ) }\end{array}$} & $\begin{array}{l}\text { Protein I - } \\
\text { like } \\
\text { substances }\end{array}$ & (a.u.) & $\begin{array}{c}76782 \pm \\
11481\end{array}$ & $63888 \pm 13125$ & 0.01 & 16.8 \\
\hline & $\begin{array}{l}\text { Protein II- } \\
\text { like } \\
\text { substances }\end{array}$ & (a.u.) & $\begin{array}{l}109615 \pm \\
16481\end{array}$ & $111503 \pm 16784$ & 0.76 & 0 \\
\hline & $\begin{array}{l}\text { Soluble } \\
\text { microbial- } \\
\text { by-product } \\
\text { like } \\
\text { substances }\end{array}$ & (a.u.) & $\begin{array}{c}74519 \pm \\
14556\end{array}$ & $73440 \pm 13358$ & 0.84 & 1.4 \\
\hline & $\begin{array}{l}\text { Fulvic acid- } \\
\text { like } \\
\text { substances }\end{array}$ & (a.u.) & $\begin{array}{l}183705 \pm \\
23176\end{array}$ & $176294 \pm 27232$ & 0.44 & 4.0 \\
\hline & $\begin{array}{l}\text { Humic acid- } \\
\text { like } \\
\text { substances }\end{array}$ & (a.u.) & $\begin{array}{c}268701 \pm \\
39320\end{array}$ & $255163 \pm 36929$ & 0.35 & 5.0 \\
\hline \multirow{7}{*}{$\begin{array}{l}\text { IC (filtered } \\
\text { through } 0.45 \mu \mathrm{m} \text { ) }\end{array}$} & F & $\mathrm{mg} / \mathrm{L}$ & $1.95 \pm 1.0$ & $2.51 \pm 1.87$ & 0.32 & 0 \\
\hline & $\mathrm{Cl}$ & $\mathrm{mg} / \mathrm{L}$ & $\begin{array}{c}125.08 \pm \\
19.93\end{array}$ & $135.93 \pm 56.35$ & 0.49 & 0 \\
\hline & $\mathrm{NO}_{2}$ & $\mathrm{mg} / \mathrm{L}$ & $0.00 \pm 0.00$ & $0.09 \pm 0.36$ & 0.97 & 0 \\
\hline & $\mathrm{Br}$ & $\mathrm{mg} / \mathrm{L}$ & $0.00 \pm 0.00$ & $0.00 \pm 0.00$ & 0.33 & - \\
\hline & $\mathrm{NO}_{3}$ & $\mathrm{mg} / \mathrm{L}$ & $1.18 \pm 0.49$ & $0.98 \pm 0.85$ & 0.44 & 16.8 \\
\hline & $\mathrm{PO}_{4}$ & $\mathrm{mg} / \mathrm{L}$ & $7.10 \pm 3.27$ & $6.32 \pm 2.27$ & 0.53 & 10.9 \\
\hline & $\mathrm{SO}_{4}$ & $\mathrm{mg} / \mathrm{L}$ & $46.50 \pm 3.30$ & $48.51 \pm 14.29$ & 0.60 & 0 \\
\hline \multirow{3}{*}{$\begin{array}{l}\text { ICP-OES (filtered } \\
\text { through } 0.45 \mu \mathrm{m} \text { ) }\end{array}$} & $\mathrm{Na}$ & $\mathrm{mg} / \mathrm{L}$ & $78.91 \pm 0.90$ & $77.77 \pm 1.09$ & 0.83 & 1.4 \\
\hline & $\mathrm{Mg}$ & $\mathrm{mg} / \mathrm{L}$ & $8.42 \pm 0.08$ & $8.14 \pm 0.08$ & 0.51 & 3.3 \\
\hline & $\mathrm{Ca}$ & $\mathrm{mg} / \mathrm{L}$ & $24.89 \pm 0.13$ & $23.48 \pm 0.14$ & 0.29 & 5.7 \\
\hline
\end{tabular}




\subsubsection{Membrane Foulants Analysis}

\section{Foulants Morphology}

During intermittent filtration (PVDF membrane $(0.08 \mu \mathrm{m})$ for $1.25 \mathrm{~h}$ filtration), different physical cleaning protocols were employed. The filtrations were stopped during a filtration cycle, after which the fouled membranes were carefully taken from the filtration cells and the cake layer foulant morphology was observed by SEM (Figure 30). In contrast to the clean membrane (Figure 30 a), the foulants on the membrane surface were obviously observed during DMF filtration of wastewater with periodical physical flushing (Figure $30 \mathrm{~b}$-e).

In addition, the operation and physical cleaning conditions could influence the morphology. In detail, the more heterogeneous foulants (especially depositions of larger fragments) were abundant on the membrane surface during DMF with wastewater flushing (Figure $30 \mathrm{~b}$ ). Similar SEM images of foulants morphologies under cleaning conditions with tap water flushing at different temperatures $\left(25^{\circ} \mathrm{C}\right.$, Figure $30 \mathrm{c} ; 50{ }^{\circ} \mathrm{C}$, Figure $\left.30 \mathrm{~d}\right)$ were observed, in both of which more uniform depositions with greater number of rod-shaped bacteria were visible. While, after multi-cycle intermittent filtration (with $50{ }^{\circ} \mathrm{C}$ tap water at a crossflow velocity of $0.4 \mathrm{~m} / \mathrm{s}$ ), the coverage of the homogenous depositions on the membrane was uneven, i.e., some areas of the membrane were not covered by foulants.
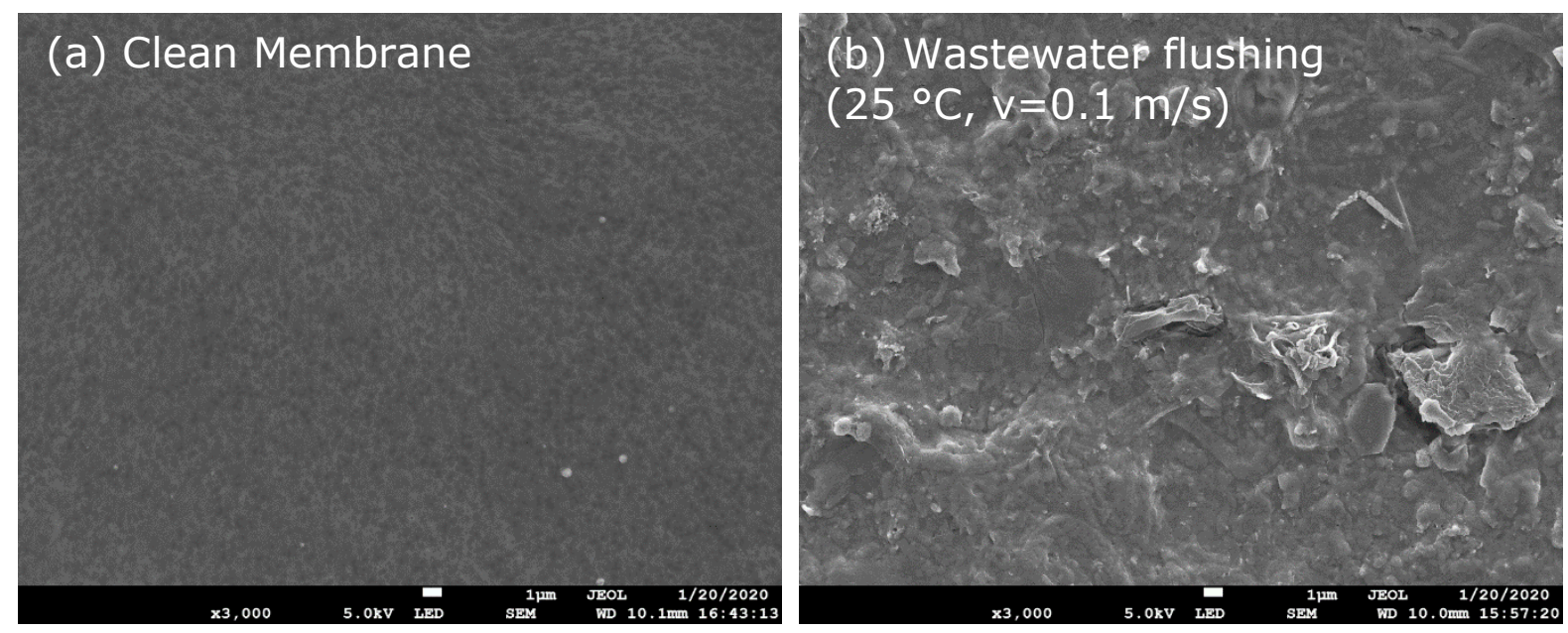

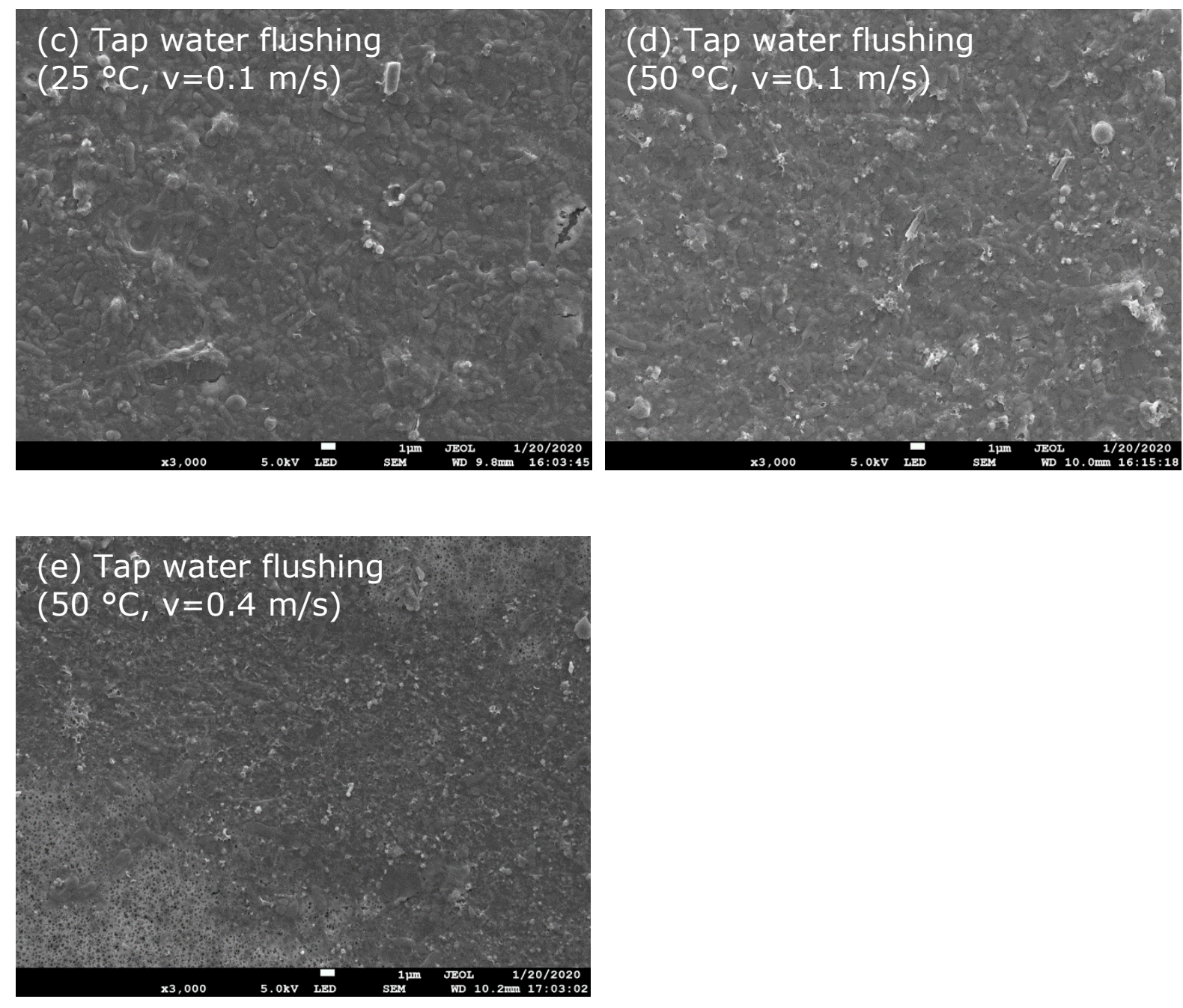

Figure 30. SEM images of the cake layer foulants after filtration at different conditions ( ×3000 magnification; 1,25 h-filtration with 10 min flushing)

\section{Soluble Foulant Characteristics}

In order to examine the membrane foulants under different filtration operation conditions, the membranes were taken out of the filtration cells at the end of filtration experiments (after a filtration cycle). The foulants were then carefully removed from the membrane by sonication and the foulant characteristics were examined. The analytical results are presented in Table 8. 
The foulants on the membrane with wastewater flushing at $0.1 \mathrm{~m} / \mathrm{s}$ and with heated tap water flushing at $0.4 \mathrm{~m} / \mathrm{s}$ had comparable DOC levels, which were lower than that with cold and heated tap water flushing at $0.1 \mathrm{~m} / \mathrm{s}$. This implied that increasing the flow velocity reduces organic fouling more efficiently than changing cleaning water types. In detail, the concentration of Biopolymers was especially low in the foulants from wastewater flushing, however, the standard deviation was significantly higher for the other foulants. This could be attributed to a high variation of Biopolymers when tap water was used for flushing. The main differences of organic foulants can be seen in the Building Block concentration, where foulants from the heated tap water operation at $0.4 \mathrm{~m} / \mathrm{s}$ showed the lowest concentration. Nevertheless, all foulant groups presented most abundantly fulvic acid-like substances (29 to $38 \%$ ) followed by Protein I-like substances ( 21 to $34 \%$ ). However, the total volumetric intensity was the lowest for the foulants from operation with heated tap water flushing at $0.4 \mathrm{~m} / \mathrm{s}$.

In addition, $\mathrm{Cl}$ and $\mathrm{Ca}$ were the abundant inorganic anion and cation components $(\sim 49 \pm 4 \%$ and $\sim 59 \pm 1 \%$ respectively) present in the cake layer foulants, regardless of the physical cleaning condition (Table 8). The foulants from the filtration with wastewater flushing contained more $\mathrm{NO}_{3}$ and $\mathrm{PO}_{4}$, possibly due to the nature of wastewater (containing $\mathrm{NO}_{3}$ and $\mathrm{PO}_{4}$, Table 7) and their potential deposition on the formed cake layer during the filtration period. Nevertheless, the total amounts of the tested inorganic foulants were almost comparable in the cake layers foulants under the four physical cleaning conditions. However, the $\mathrm{F}$ concentration in the foulants from tap water flushing, especially heated, was significantly higher than in the foulants from wastewater flushing. This may be attributed to a changing membrane integrity caused by the operation conditions or the presence of $\mathrm{F}$ element in the tap water.

\section{Microbial Foulant Characteristics}

To illustrate microbial foulant depositions on the membrane, the cell density was described in terms of live and dead cell numbers detected by flow cytometry and ATP measurement, shown in Table 8. Overall, compared to live cells, more dead cells were found on the membrane surface after physical cleaning, regardless of the physical cleaning protocols. The number of live cells in the foulants from the filtration with wastewater flushing was slightly higher than those with tap water flushing, which corresponded to the ATP trend. This phenomenon was associated with the nature of wastewater that contains a great number of bacteria. 
Table 8. Analysis of soluble foulant and microbial foulant characteristics

\begin{tabular}{|c|c|c|c|c|c|c|}
\hline $\begin{array}{l}\text { Measure- } \\
\text { ment } \\
\text { method }\end{array}$ & Parameter & $\begin{array}{c}\text { Unit } \\
\left({ }^{*} 0.03 \mathrm{~L}\right)\end{array}$ & $\begin{array}{c}\text { With } \\
\text { waste- } \\
\text { water } \\
\text { flushing } \\
\left(25^{\circ} \mathrm{C} \text {, }\right. \\
0.1 \mathrm{~m} / \mathrm{s}) \\
\mathrm{n}=4\end{array}$ & $\begin{array}{c}\text { With tap } \\
\text { water } \\
\text { flushing } \\
\left(25^{\circ} \mathrm{C}\right. \\
0.1 \mathrm{~m} / \mathrm{s}) \\
\mathrm{n}=2\end{array}$ & $\begin{array}{c}\text { With tap } \\
\text { water } \\
\text { flushing } \\
\left(50^{\circ} \mathrm{C}\right. \\
0.1 \mathrm{~m} / \mathrm{s}) \\
\mathrm{n}=2\end{array}$ & $\begin{array}{c}\text { With tap } \\
\text { water } \\
\text { flushing } \\
\left(50^{\circ} \mathrm{C}\right. \\
0.4 \mathrm{~m} / \mathrm{s}) \\
\mathrm{n}=15\end{array}$ \\
\hline \multirow{6}{*}{$\begin{array}{l}\text { LC-OCD } \\
\text { (filtered } \\
\text { through } \\
0.22 \mu \mathrm{m} \text { ) }\end{array}$} & DOC & $\mu \mathrm{g} / \mathrm{cm}^{2}$ & $\begin{array}{c}1500 \pm \\
161\end{array}$ & $3217 \pm 84$ & $2241 \pm 30$ & $\begin{array}{c}1646 \pm \\
921\end{array}$ \\
\hline & $\begin{array}{l}\text { Biopoly- } \\
\text { mers }\end{array}$ & $\mu \mathrm{g} / \mathrm{cm}^{2}$ & $88 \pm 21$ & $376 \pm 45$ & $144 \pm 34$ & $184 \pm 164$ \\
\hline & $\begin{array}{l}\text { Humic } \\
\text { acid }\end{array}$ & $\mu \mathrm{g} / \mathrm{cm}^{2}$ & $\begin{array}{c}0.00 \pm \\
0.00\end{array}$ & $\begin{array}{c}0.00 \pm \\
0.00\end{array}$ & $\begin{array}{c}0.00 \pm \\
0.00\end{array}$ & $\begin{array}{c}0.00 \pm \\
0.00\end{array}$ \\
\hline & $\begin{array}{l}\text { Building } \\
\text { blocks }\end{array}$ & $\mu \mathrm{g} / \mathrm{cm}^{2}$ & $572 \pm 57$ & $1084 \pm 73$ & $707 \pm 99$ & $386 \pm 134$ \\
\hline & $\begin{array}{l}\text { LMW } \\
\text { Neutrals }\end{array}$ & $\mu \mathrm{g} / \mathrm{cm}^{2}$ & $406 \pm 61$ & $1258 \pm 26$ & $682 \pm 15$ & $675 \pm 579$ \\
\hline & $\begin{array}{l}\text { LMW } \\
\text { Acids }\end{array}$ & $\mu \mathrm{g} / \mathrm{cm}^{2}$ & $257 \pm 79$ & $283 \pm 6$ & $200 \pm 33$ & $196 \pm 298$ \\
\hline \multirow{5}{*}{$\begin{array}{l}\text { EEM } \\
\text { (filtered } \\
\text { through } \\
0.45 \mu \mathrm{m} \text { ) }\end{array}$} & $\begin{array}{l}\text { Protein I- } \\
\text { like } \\
\text { substances }\end{array}$ & a.u. $/ \mathrm{cm}^{2}$ & $\begin{array}{c}13677 \pm \\
1339\end{array}$ & $\begin{array}{c}13945 \pm \\
5994\end{array}$ & $\begin{array}{c}15040 \pm \\
1815\end{array}$ & $\begin{array}{c}12784 \pm \\
5303\end{array}$ \\
\hline & $\begin{array}{l}\text { Protein II- } \\
\text { like } \\
\text { substances }\end{array}$ & a.u. $/ \mathrm{cm}^{2}$ & $\begin{array}{c}8781 \pm \\
667\end{array}$ & $\begin{array}{c}7772 \pm \\
535\end{array}$ & $\begin{array}{c}5609 \pm \\
798\end{array}$ & $\begin{array}{c}7529 \pm \\
5572\end{array}$ \\
\hline & $\begin{array}{l}\text { Soluble } \\
\text { microbial- } \\
\text { by-product } \\
\text { like } \\
\text { substances }\end{array}$ & a.u. $/ \mathrm{cm}^{2}$ & $\begin{array}{c}7757 \pm \\
694\end{array}$ & $\begin{array}{c}5175 \pm \\
3169\end{array}$ & $\begin{array}{c}7489 \pm \\
1052\end{array}$ & $\begin{array}{c}5558 \pm \\
2319\end{array}$ \\
\hline & $\begin{array}{l}\text { Fulvic } \\
\text { acid-like } \\
\text { substances }\end{array}$ & a.u. $/ \mathrm{cm}^{2}$ & $\begin{array}{c}13636 \pm \\
1585\end{array}$ & $\begin{array}{c}24862 \pm \\
4913\end{array}$ & $\begin{array}{c}13032 \pm \\
3577\end{array}$ & $\begin{array}{c}17994 \pm \\
12713\end{array}$ \\
\hline & $\begin{array}{l}\text { Humic } \\
\text { acid-like } \\
\text { substances }\end{array}$ & a.u. $/ \mathrm{cm}^{2}$ & $\begin{array}{c}3876 \pm \\
296\end{array}$ & $\begin{array}{c}16047 \pm \\
11982\end{array}$ & $\begin{array}{c}2862 \pm \\
387\end{array}$ & $\begin{array}{c}3798 \pm \\
2118\end{array}$ \\
\hline \multirow{7}{*}{$\begin{array}{l}\text { IC } \\
\text { (filtered } \\
\text { through } \\
0.45 \mu \mathrm{m} \text { ) }\end{array}$} & $\mathrm{F}$ & $\mu \mathrm{g} / \mathrm{cm}^{2}$ & $37 \pm 56$ & $164 \pm 2$ & $234 \pm 74$ & $250 \pm 233$ \\
\hline & $\mathrm{Cl}$ & $\mu \mathrm{g} / \mathrm{cm}^{2}$ & $267 \pm 30$ & $541 \pm 5$ & $552 \pm 19$ & $365 \pm 82$ \\
\hline & $\mathrm{NO}_{2}$ & $\mu \mathrm{g} / \mathrm{cm}^{2}$ & $0 \pm 0$ & $0 \pm 0$ & $0 \pm 0$ & $7 \pm 26$ \\
\hline & $\mathrm{Br}$ & $\mu \mathrm{g} / \mathrm{cm}^{2}$ & $0 \pm 0$ & $0 \pm 0$ & $0 \pm 0$ & $0 \pm 0$ \\
\hline & $\mathrm{NO}_{3}$ & $\mu \mathrm{g} / \mathrm{cm}^{2}$ & $146 \pm 130$ & $0 \pm 0$ & $0 \pm 0$ & $46 \pm 103$ \\
\hline & $\mathrm{PO}_{4}$ & $\mu \mathrm{g} / \mathrm{cm}^{2}$ & $133 \pm 46$ & $100 \pm 6$ & $42 \pm 42$ & $39 \pm 51$ \\
\hline & $\mathrm{SO}_{4}$ & $\mu \mathrm{g} / \mathrm{cm}^{2}$ & $163 \pm 19$ & $183 \pm 37$ & $176 \pm 124$ & $7 \pm 15$ \\
\hline \multirow{3}{*}{$\begin{array}{l}\text { ICP-OES } \\
\text { (filtered } \\
\text { through } \\
0.45 \mu \mathrm{m} \text { ) }\end{array}$} & $\mathrm{Na}$ & $\mu \mathrm{g} / \mathrm{cm}^{2}$ & $49 \pm 3$ & $217 \pm 5$ & $160 \pm 2$ & $100 \pm 4$ \\
\hline & $\mathrm{Mg}$ & $\mu \mathrm{g} / \mathrm{cm}^{2}$ & $17 \pm 1$ & $37 \pm 1$ & $28 \pm 1$ & $24 \pm 1$ \\
\hline & $\mathrm{Ca}$ & $\mu \mathrm{g} / \mathrm{cm}^{2}$ & $143 \pm 2$ & $206 \pm 2$ & $358 \pm 3$ & $175 \pm 2$ \\
\hline
\end{tabular}




\begin{tabular}{lllcccc}
\hline & Live cells & $\times 10^{7} / \mathrm{cm}^{2}$ & $10.1 \pm 2.2$ & $6.3 \pm 0.3$ & $0.8 \pm 0.3$ & $2.9 \pm 3.1$ \\
Flow & Dead cells & $\times 10^{7} / \mathrm{cm}^{2}$ & $10.4 \pm 4.6$ & $39.4 \pm 1.4$ & $42.8 \pm 1.0$ & $12.8 \pm$ \\
Cytometer & & & $1877 \pm$ & 1642 & & 14.4 \\
ATP Kit & ATP & \multirow{2}{*}{$\mathrm{pg} / \mathrm{cm}^{2}$} & 255 & \pm 100 & $251 \pm 13$ & $650 \pm 832$ \\
& & & & & \\
\hline
\end{tabular}

\section{Characteristics of Membranes after Cleaning}

In order to examine the effects of irreversible and irremovable foulants on membrane properties, the membranes were taken out of the filtration cells at the end of filtration experiments with different cleaning conditions. The foulants were then removed from the membrane by sonication. The residual membranes were then dried before contact angle and FTIR analysis.

The contact angles of the virgin and fouled membranes after different physical cleaning are shown in Table 9. The virgin PVDF membrane had a lower contact angle at $\sim 32^{\circ}$, indicating a more hydrophilic nature. Almost no significant differences among the membranes used in filtrations with wastewater and tap water flushing were observed. These membranes appeared to be more hydrophobic $\left(>90^{\circ}\right)$, indicating the residual foulants had a more hydrophobic nature. However, the membrane after long-term filtration operation showed a slightly lower contact angle $\left(\sim 85^{\circ}\right)$. As chemical-enhanced physical cleaning was employed during long-term operation, it was suggested that the chemical cleaning removed part of the physically irreversible foulants, leading to less hydrophobicity.

Table 9. Contact angles of the clean and fouled membranes

\begin{tabular}{lc}
\hline \multicolumn{1}{c}{ Membrane } & Contact angle $\left({ }^{\circ}\right)$ \\
\hline Virgin membrane & 32 \\
$1.25 \mathrm{~h}$ filtration + wastewater $\left(25^{\circ} \mathrm{C}\right)$ flushing $(0.1 \mathrm{~m} / \mathrm{s})$ & $101 \pm 4$ \\
$1.25 \mathrm{~h}$ filtration + tap water $\left(25^{\circ} \mathrm{C}\right)$ flushing $(0.1 \mathrm{~m} / \mathrm{s})$ & 97 \\
$1.25 \mathrm{~h}$ filtration + tap water $\left(50^{\circ} \mathrm{C}\right)$ flushing $(0.1 \mathrm{~m} / \mathrm{s})$ & 95 \\
$1.25 \mathrm{~h}$ filtration + tap water $\left(50^{\circ} \mathrm{C}\right)$ flushing $(0.4 \mathrm{~m} / \mathrm{s})$ & $95 \pm 6$ \\
Long-term operation $\left(1.25 \mathrm{~h}\right.$ filtration + tap water $\left(50{ }^{\circ} \mathrm{C}\right)$ & 85 \\
flushing $(0.4 \mathrm{~m} / \mathrm{s})+$ periodical chemical cleaning $)$ & \\
\hline
\end{tabular}

In addition, FTIR profiles of the virgin PVDF membrane and the physically cleaned membranes were examined, as indicated in Figure 31. For a typical virgin PVDF membrane, the major peaks associated with chemical components include: (1) $\mathrm{C}-\mathrm{H}$ bending, aliphatic (variable strength), (2) Skeletal vibration, (3) $\mathrm{C}-\mathrm{H}$ bending $\mathrm{C}=\mathrm{C}-\mathrm{H}$ (medium to strong) and skeletal vibration (weak) and (4) ring in and out of plane bending (variable strength). Obviously, after $1.25 \mathrm{~h}$ filtrations and tap water flushing, the FTIR pattern of the membrane was similar to that of the virgin membrane. This suggests that the presence of irreversible and irremovable foulants did not fully cover the membrane surface or block the membrane pores during short-term operation. 
However, after a long-term DMF with periodically physical and chemical cleaning, it was observed that the peaks 1, 2 and 3 were not present and the intensity of peak 4 increased on the physically cleaned membrane. In addition, a new peak 5 associated with skeletal vibration (weak) and C-O stretch (variable strength) appeared. This could be associated with two possibilities, (1) more accumulation of irremovable foulants in the membrane with extending filtration cycles, which led to a fully covered membrane surface or blocked membrane pores to modify the membrane surface property; (2) the partial loss of membrane integrity, which contributed to the disappearance of key function groups.

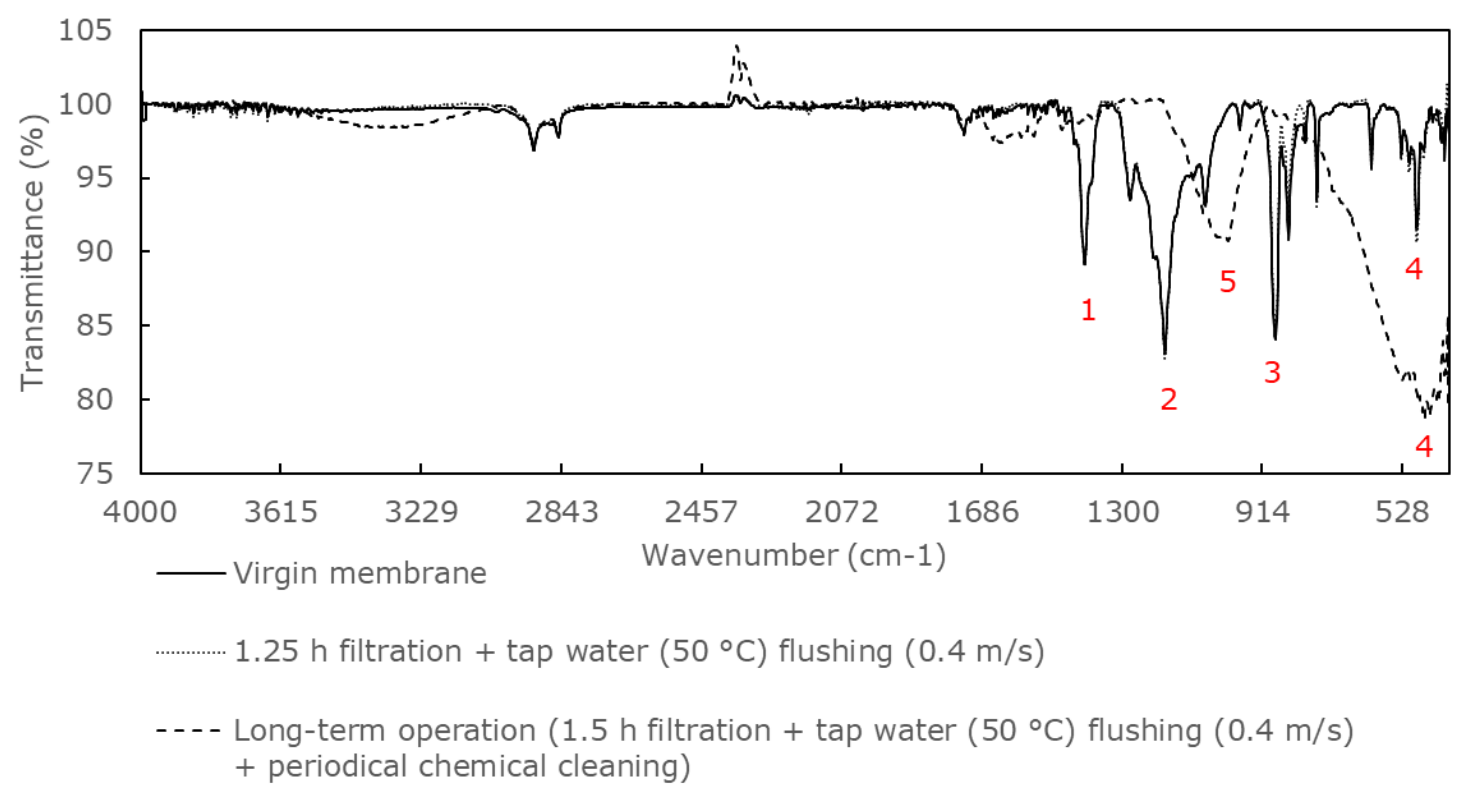

Figure 31. FTIR profiles of virgin and fouled membranes 



\section{General Discussion and Outlook}

The experimental results showed that the application of DMF on simulated Icelandic wastewater was possible by applying a limited cleaning protocol. More, no major pretreatments are required to ensure a stable operation. The cleaning protocol was thus reduced compared to previously reported studies (presented in 2.3 to 2.5). This could be attributed to the low strength feed. On the one hand, the heating of the flushing water is energy-intensive and could cause a rise in costs. In Iceland, however, the availability of low-cost renewable energy makes this cleaning protocol favorable. In particular, geothermal water, readily available in many parts of the country could potentially be used directly for flushing, which has to be analyzed in further studies.

As DMF can be used for wastewater treatment with varying influent rates it could be especially suitable for decentralized wastewater treatment systems. The demography in Iceland varies significantly over the year, as the high tourist season is limited to the summer. The touristic hotspots are mostly located in rural communities, which often have limited wastewater treatment systems. Therefore, DMF could be implemented in these places to ensure sufficient wastewater treatment throughout the year and ensure the environment is not harmed by the high number of tourists (Icelandic Tourist Board, 2019). In general, DMF is a good solution for decentralized wastewater treatment, as previously reported in the literature (Guilbaud et al., 2010). Besides the good treatment efficiency, DMF also requires low maintenance (operation can be easily auto-controlled by the commercial programme) and presents high adaptability (membrane modules and fluxes can be regulated based on treatment capacity) (Guilbaud et al., 2010; Hey et al., 2017; Ravazzini et al., 2005).

DMF could also be adapted to the existing wastewater treatment system in the capital area. The current treatment consists of grit and fat removal. This is similar to the simulated wastewater used in this study and could therefore be a sufficient pre-treatment for DMF. In addition, the removal efficiency of DMF greatly depends on the pore size of the employed membranes. For instance, a MF membrane doesn't show efficient removals for soluble components, therefore micropollutants such as pharmaceuticals, microplastics, and toxic detergents could be present in the permeate. When targeting the removal of these components specifically, for example in hospital wastewater treatment, ultrafiltration or nanofiltration is suggested to be added as a secondary filtration process followed by microfiltration.

In this study, however, the experimental study is limited by the small-scale setup and laboratory conditions. The presented results must be confirmed by long-term operation. Moreover, the cleaning protocol should be further optimized with a membrane suitable for regular chemical cleaning, high temperatures and high shear. Especially, future studies on pilot-scale setups should be conducted using real Icelandic wastewater under Icelandic climatic conditions. Finally, the concept of implementing DMF in Iceland should be further studied by conducting life cycle and cost assessments. 



\section{Conclusions}

In this study, six major findings are summarized:

(1) Recent studies show that DMF is a promising alternative for the treatment of low-strength Icelandic wastewater and other decentralized wastewater treatment systems, due to its high modularity and high adaptability to wastewater characteristics and varying volume.

(2) PVDF MF membrane $(0.08 \mu \mathrm{m})$ was identified as a suitable membrane for DMF operation in terms of membrane performance and permeate water quality.

(3) During short-term continuous filtration, physically reversible cake layer fouling was predominant and almost no irreversible/ irremovable fouling could be detected. Physical cleaning benefitted to remove loosely attached cake layer and caused an expansion of the tightly attached cake layer, which was observed by OCT. After multi-cycle intermittent filtration with periodical physical cleaning, the contribution of irreversible/ irremovable fouling to the total fouling was apparent because the compactness of such tightly attached cake layer allowed it shifting to irreversible/ irremovable fouling.

(4) A combination of chemical-enhanced physical cleaning with periodical physical cleaning (hot water flushing at a high flow velocity) was found to be effective in membrane fouling control during long-term DMF operation. As spring hot water is naturally available in Iceland, DMF for Icelandic wastewater treatment is economically feasible.

(5) During DMF of wastewater, a combination of organic and inorganic foulants was attributed to membrane fouling, while biological fouling is less prominent, especially employing periodically tap water flushing.

(6) Compared to MBRs, a relatively higher frequency chemical-enhanced physical cleaning was employed in DMF processes. Therefore, the organic membrane integrity loss needs to be paid more attention to, especially during real operation. Inorganic membranes could be an alternative, which requires future study.

To conclude, the findings in this study showed that DMF could be a promising solution to improve the situation of wastewater treatment in Iceland. However, further studies need to be conducted, in detail, (1) designing DMF system and scaling-up DMF operation; (2) optimizing long-term filtration conditions and analyzing fouling characteristics; (3) economic analysis and life cycle assessment of DMF in an Icelandic scenario and developing countries (such as in Africa and South Asia) in areas where no centralized wastewater treatment facilities are available. 



\section{References}

Akbari, A., Remigy, J. C., and Aptel, P. (2002). Treatment of textile dye effluent using a polyamide-based nanofiltration membrane. Chemical Engineering and ProcessingProcess Intensification, 41(7), 601-609. doi:Pii S0255-2701(01)00181-7

Anis, S. F., Hashaikeh, R., and Hilal, N. (2019). Reverse osmosis pretreatment technologies and future trends: A comprehensive review. Desalination, 452, 159-195. doi 10.1016/S0255-2701(01)00181-7

APHA, A. P. H. A. (1998). Standard Methods for the examination of water and wastewater, 20th ed. Washington DC.

Barbosa, M. O., Moreira, N. F. F., Ribeiro, A. R., Pereira, M. F. R., and Silva, A. M. T. (2016). Occurrence and removal of organic micropollutants: An overview of the watch list of EU Decision 2015/495. Water Res, 94, 257-279. doi:10.1016/j.watres.2016.02.047

Boddu, V. M., Paul, T., Page, M. A., Byl, C., Ward, L., and Ruan, J. (2016). Gray water recycle: Effect of pretreatment technologies on low pressure reverse osmosis treatment. Journal of Environmental Chemical Engineering, 4(4), 4435-4443. doi:10.1016/j.jece.2016.09.031

Brezinski, M. (2006). Optical Coherence Tomography. Optical Coherence Tomography, 4. doi:10.1016/B978-0-444-53632-7.00416-0

Butler, R., and MacCormick, T. (1996). Opportunities for decentralized treatment, sewer mining and effluent re-use. Desalination, 106(1-3), 273-283.

Chen, W., Westerhoff, P., Leenheer, J. A., and Booksh, K. (2003). Fluorescence Excitation-Emission Matrix Regional Integration to Quantify Spectra for Dissolved Organic Matter. Environmental Science and Technology, 37(24), 5701-5710. doi:10.1021/es034354c

Crittenden, J. C., Rhode Trussell, R., Hand, D. W., Howe, K. J., and Tchobanoglous, G. (2012). MWH's Water Treatment: Principles and Design, Third Edition: John Wiley and Sons, Inc.

Dreszer, C., Wexler, A. D., Drusova, S., Overdijk, T., Zwijnenburg, A., Flemming, H. C., . . . Vrouwenvelder, J. S. (2014). In-situ biofilm characterization in membrane systems using Optical Coherence Tomography: formation, structure, detachment and impact of flux change. Water Res, 67, 243-254. doi:10.1016/j.watres.2014.09.006

Drews, A. (2010). Membrane fouling in membrane bioreactors-Characterisation, contradictions, cause and cures. Journal of Membrane Science, 363(1-2), 1-28. doi:10.1016/j.memsci.2010.06.046

EFLA Engineering. (2019). Retrieved from https://www.eflaengineers.com/projects/environment/wastewater-treatment-plant

European Environment Agency. (2017, 21.01.19). Urban waste water treatment. Retrieved from https://www.eea.europa.eu/data-and-maps/indicators/urban-waste-watertreatment/urban-waste-water-treatment-assessment-4

Field, R. W., and Pearce, G. K. (2011). Critical, sustainable and threshold fluxes for membrane filtration with water industry applications. Adv Colloid Interface Sci, 164(1-2), 38-44. doi:10.1016/j.cis.2010.12.008

Gong, H., Jin, Z., Wang, Q., Zuo, J., Wu, J., and Wang, K. (2017). Effects of adsorbent cake layer on membrane fouling during hybrid coagulation/adsorption microfiltration for 
sewage organic recovery. Chemical Engineering Journal, 317, 751-757. doi:10.1016/j.cej.2017.02.122

Guilbaud, J., Massé, A., Andrès, Y., Combe, F., and Jaouen, P. (2010). Laundry water recycling in ship by direct nanofiltration with tubular membranes. Resour. Conserv. Recy., 55(2), 148-154. doi:10.1016/j.resconrec.2010.09.001

Hedaoo, M. N., Bhole, A. G., Ingole, N. W., and Hung, Y.-T. (2012). BIOLOGICAL WASTEWATER TREATMENT. In Handbook of Environment and Waste Management (pp. 431-473).

Hey, T., Bajraktari, N., Davidsson, A., Vogel, J., Madsen, H. T., Helix-Nielsen, C., . . . Jonsson, K. (2018). Evaluation of direct membrane filtration and direct forward osmosis as concepts for compact and energy-positive municipal wastewater treatment. Environ Technol, 39(3), 264-276. doi:10.1080/09593330.2017.1298677

Hey, T., Vaananen, J., Heinen, N., la Cour Jansen, J., and Jonsson, K. (2017). Potential of combining mechanical and physicochemical municipal wastewater pre-treatment with direct membrane filtration. Environ Technol, 38(1), 108-115. doi:10.1080/09593330.2016.1186746

Hoinkis, J., Deowan, S. A., Panten, V., Figoli, A., Huang, R. R., and Drioli, E. (2012). Membrane Bioreactor (MBR) Technology - a Promising Approach for Industrial Water Reuse. Procedia Engineering, 33, 234-241. doi:https://doi.org/10.1016/j.proeng.2012.01.1199

Huang, B. C., Guan, Y. F., Chen, W., and Yu, H. Q. (2017). Membrane fouling characteristics and mitigation in a coagulation-assisted microfiltration process for municipal wastewater pretreatment. Water Res, 123, 216-223. doi:10.1016/j.watres.2017.06.080

Huber, S. A., Balz, A., Abert, M., \& Pronk, W. (2011). Characterisation of aquatic humic and non-humic matter with size-exclusion chromatography-organic carbon detection-organic nitrogen detection (LC-OCD-OND). Water Res, 45(2), 879-885. doi:10.1016/j.watres.2010.09.023

Iceland Review. (2017). Sewage Treatment Lacking in Iceland. Retrieved from https://www.icelandreview.com/news/sewage-treatment-lacking-iceland/

Icelandic Tourist Board. (2019). Environmental Issues. Retrieved from https://www.ferdamalastofa.is/en/quality-and-environment/environmental-issues

IMO, I. M. O. (2019). Climatological Data. Retrieved from https://en.vedur.is/climatology/data/

Jin, Z., Gong, H., Temmink, H., Nie, H., Wu, J., Zuo, J., and Wang, K. (2016). Efficient sewage pre-concentration with combined coagulation microfiltration for organic matter recovery. Chemical Engineering Journal, 292, 130-138. doi:10.1016/j.cej.2016.02.024

Jin, Z., Meng, F., Gong, H., Wang, C., and Wang, K. (2017). Improved low-carbonconsuming fouling control in long-term membrane-based sewage pre-concentration: The role of enhanced coagulation process and air backflushing in sustainable sewage treatment. Journal of Membrane Science, 529, 252-262. doi:10.1016/j.memsci.2017.02.009

Judd, S. (2006). The MBR Book: Principles and Applications of Membrane Bioreactors,. Elsevier, Boston, MA.

Kim, J.-O., Jung, J.-T., and Chung, J. (2007a). Treatment performance of metal membrane microfiltration and electrodialysis integrated system for wastewater reclamation. Desalination, 202(1-3), 343-350. doi:10.1016/j.desal.2005.12.073 
Kim, R.-H., Lee, S., Jeong, J., Lee, J.-H., and Kim, Y.-K. (2007b). Reuse of greywater and rainwater using fiber filter media and metal membrane. Desalination, 202(1-3), 326332. doi:10.1016/j.desal.2005.12.071

Kimura, K., Honoki, D., and Sato, T. (2017). Effective physical cleaning and adequate membrane flux for direct membrane filtration (DMF) of municipal wastewater: Upconcentration of organic matter for efficient energy recovery. Separation and Purification Technology, 181, 37-43. doi:10.1016/j.seppur.2017.03.005

Koyuncu, I. (2003). Direct filtration of Procion dye bath wastewaters by nanofiltration membranes: flux and removal characteristics. Journal of Chemical Technology and Biotechnology, 78(12), 1219-1224. doi:10.1002/jctb.924

Lateef, S. K., Soh, B. Z., and Kimura, K. (2013). Direct membrane filtration of municipal wastewater with chemically enhanced backwash for recovery of organic matter. Bioresour Technol, 150, 149-155. doi:10.1016/j.biortech.2013.09.111

Li, F., Behrendt, J., Wichmann, K., and Otterpohl, R. (2008). Resources and nutrients oriented greywater treatment for non-potable reuses. Water Sci Technol, 57(12), 1901-1907. doi:10.2166/wst.2008.601

Lin, J., Ye, W., Baltaru, M.-C., Tang, Y. P., Bernstein, N. J., Gao, P., . . Van der Bruggen, B. (2016). Tight ultrafiltration membranes for enhanced separation of dyes and $\mathrm{Na}_{2} \mathrm{SO}_{4}$ during textile wastewater treatment. J. Membr. Sci., 514, 217-228. doi:10.1016/j.memsci.2016.04.057

López Zavala, M. Á., Suárez Pérez, L. B., Reynoso-Cuevas, L., and Funamizu, N. (2014). Pre-filtration for enhancing direct membrane filtration of graywater from washing machine discharges. Ecological Engineering, 64, 116-119. doi:10.1016/j.ecoleng.2013.12.049

Luo, J., Zhu, Z., Ding, L., Bals, O., Wan, Y., Jaffrin, M. Y., and Vorobiev, E. (2013). Flux behavior in clarification of chicory juice by high-shear membrane filtration: Evidence for threshold flux. Journal of Membrane Science, 435, 120-129. doi:10.1016/j.memsci.2013.01.057

Luo, L., Dzakpasu, M., Yang, B., Zhang, W., Yang, Y., and Wang, X. C. (2019). A novel index of total oxygen demand for the comprehensive evaluation of energy consumption for urban wastewater treatment. Applied Energy, 236, 253-261. doi:10.1016/j.apenergy.2018.11.101

Meng, F. G., Zhang, S. Q., Oh, Y., Zhou, Z. B., Shin, H. S., and Chae, S. R. (2017). Fouling in membrane bioreactors: An updated review. Water Research, 114, 151-180. doi:10.1016/j.watres.2017.02.006

Mezohegyi, G., Bilad, M. R., and Vankelecom, I. F. (2012). Direct sewage up-concentration by submerged aerated and vibrated membranes. Bioresour Technol, 118, 1-7. doi:10.1016/j.biortech.2012.05.022

Mishima, I., and Nakajima, J. (2009). Control of membrane fouling in membrane bioreactor process by coagulant addition. Water Science and Technology, 59(7), 1255-1262. doi:10.2166/wst.2009.090

Mizuta, K., and Shimada, M. (2010). Benchmarking energy consumption in municipal wastewater treatment plants in Japan. Water Science and Technology, 62(10), 22562262. doi:10.2166/wst.2010.510

Ng, C. A., Sun, D., Bashir, M. J., Wai, S. H., Wong, L. Y., Nisar, H., . . Fane, A. G. (2013). Optimization of membrane bioreactors by the addition of powdered activated carbon. Bioresour Technol, 138, 38-47. doi:10.1016/j.biortech.2013.03.129

Oh, K. S., Poh, P. E., Chong, M. N., Chan, E. S., Lau, E. V., and Saint, C. P. (2016). Bathroom greywater recycling using polyelectrolyte-complex bilayer membrane: 
Advanced study of membrane structure and treatment efficiency. Carbohydr. Polym., 148, 161-170. doi:10.1016/j.carbpol.2016.04.039

Plappally, A. K., and Lienhard V, J. H. (2012). Energy requirements for water production, treatment, end use, reclamation, and disposal. Renewable and Sustainable Energy Reviews, 16(7), 4818-4848. doi:10.1016/j.rser.2012.05.022

Ramona, G., Green, M., Semiat, R., and Dosoretz, C. (2004). Low strength graywater characterization and treatmentby direct membrane filtration. Desalination, 170(3), 241-250. doi:10.1016/j.desal.2004.02.100

Ravazzini, A. M., van Nieuwenhuijzen, A. F., and van der Graaf, J. H. M. J. (2005). Direct ultrafiltration of municipal wastewater: comparison between filtration of raw sewage and primary clarifier effluent. Desalination, 178(1-3), 51-62. doi:10.1016/j.desal.2004.11.028

Regulation nr.798/1999 on wastewater systems (Reglugerð nr. 798/1999 um fráveitur og skólp) (1999). Retrieved from: https://www.reglugerd.is/reglugerdir/eftir-raduneytum/umhverfisraduneyti/nr/4323

Sajjad, A.-A., Yunus, M. Y. B. M., Azoddein, A. A. M., Hassell, D. G., Dakhil, I. H., and Hasan, H. A. (2019). Electrodialysis Desalination for Water and Wastewater: A Review. Chemical Engineering Journal. doi:10.1016/j.cej.2019.122231

Saleh, T. A., and Gupta, V. K. (2016). Chapter 2 - Membrane Fouling and Strategies for Cleaning and Fouling Control. In T. A. Saleh and V. K. Gupta (Eds.), Nanomaterial and Polymer Membranes (pp. 25-53): Elsevier.

Sano, T., Koga, Y., Ito, H., Duc, L. V., Hama, T., and Kawagoshi, Y. (2020). Effects of structural vulnerability of flat-sheet membranes on fouling development in continuous submerged membrane bioreactors. Bioresour Technol, 304, 123015. doi:10.1016/j.biortech.2020.123015

Sato, T., Qadir, M., Yamamoto, S., Endo, T., and Zahoor, A. (2013). Global, regional, and country level need for data on wastewater generation, treatment, and use. Agricultural Water Management, 130, 1-13. doi:10.1016/j.agwat.2013.08.007

Shi, X., Tal, G., Hankins, N. P., and Gitis, V. (2014). Fouling and cleaning of ultrafiltration membranes: A review. Journal of Water Process Engineering, 1, 121-138. doi:10.1016/j.jwpe.2014.04.003

Sim, L. N., and Fane, A. G. (2017). 4.4 Advanced Monitoring of Membrane Fouling and Control Strategies. In Comprehensive Membrane Science and Engineering (pp. 72103).

Singh, R., and Hankins, N. P. (2016). Chapter 2 - Introduction to Membrane Processes for Water Treatment. In N. P. Hankins and R. Singh (Eds.), Emerging Membrane Technology for Sustainable Water Treatment (pp. 15-52). Boston: Elsevier.

Šostar-Turk, S., Petrinić, I., and Simonič, M. (2005). Laundry wastewater treatment using coagulation and membrane filtration. Resour. Conserv. Recy., 44(2), 185-196. doi:10.1016/j.resconrec.2004.11.002

Straub, A. P., Asa, E., Zhang, W., Nguyen, T. H., and Herzberg, M. (2020). In-situ graftpolymerization modification of commercial ultrafiltration membranes for long-term fouling resistance in a pilot-scale membrane bioreactor. Chemical Engineering Journal, 382. doi:10.1016/j.cej.2019.122865

Sævarsson, R. (2018). Mechanical Sewage Treatment. Presented at Vatns- og fráveitufélag Íslands; Himnur (membranes). Retrieved from http://www.vafri.hi.is/?page id=1202

Tan, Y. Z., Mao, Z., Zhang, Y., Tan, W. S., Chong, T. H., Wu, B., and Chew, J. W. (2019). Enhancing fouling mitigation of submerged flat-sheet membranes by vibrating 3D- 
spacers. Separation and Purification Technology, 215, 70-80. doi:10.1016/j.seppur.2018.12.085

Tchobanoglous, G., Burton, F. L., Stensel, H. D., Metcalf, Eddy, I., and Burton, F. (2003). Wastewater Engineering: Treatment and Reuse: McGraw-Hill Education.

Tran, A. T. K., Zhang, Y., Lin, J., Mondal, P., Ye, W., Meesschaert, B., . . Van der Bruggen, B. (2015). Phosphate pre-concentration from municipal wastewater by selectrodialysis: Effect of competing components. Separation and Purification Technology, 141, 38-47. doi:10.1016/j.seppur.2014.11.017

Umhverfisstofnun. (2013). Report to the EFTA Surveillance Authority regarding the implementation of Directive 91/271/EU on the treatment of wastewater from agglomerations. Retrieved from https://www.ust.is/umhverfisstofnun/utgefidefni/annad-utgefid-efni/

United Nations, G. A. (2015). Transforming our World: Agenda 2030 for Sustainable Development A/RES/70/1. Retrieved from https://sustainabledevelopment.un.org/content/documents/21252030\%20Agenda\%2 0for\%20Sustainable\%20Development\%20web.pdf

Veitur. (2019). Wastewater. Retrieved from https://www.veitur.is/en/wastewater

Wan, J., Gu, J., Zhao, Q., and Liu, Y. (2016). COD capture: a feasible option towards energy self-sufficient domestic wastewater treatment. Scientific Reports, 6(1), 25054. doi:10.1038/srep25054

WHO, and UN-HABITAT. (2018). Progress on safe treatment and use of wastewater: piloting the monitoring methodology and initial findings for SDG indicator 6.3.1. Geneva.

Woźniak, M. J., and Prochaska, K. (2014). Fumaric acid separation from fermentation broth using nanofiltration (NF) and bipolar electrodialysis (EDBM). Sep. Purif. Technol., 125, 179-186. doi:10.1016/j.seppur.2014.01.051

Wu, B. (2019). Membrane-based technology in greywater reclamation: A review. Sci Total Environ, 656, 184-200. doi:10.1016/j.scitotenv.2018.11.347

Wu, B., and Fane, A. G. (2012). Microbial relevant fouling in membrane bioreactors: influencing factors, characterization, and fouling control. Membranes, 2(3), 565-584.

Wu, B., Li, Y., Lim, W., Lee, S. L., Guo, Q., Fane, A. G., and Liu, Y. (2017). Single-stage versus two-stage anaerobic fluidized bed bioreactors in treating municipal wastewater: Performance, foulant characteristics, and microbial community. Chemosphere, 171, 158-167. doi:10.1016/j.chemosphere.2016.12.069

Wu, B., Zhang, Y., Mao, Z., Tan, W. S., Tan, Y. Z., Chew, J. W., . . Fane, A. G. (2019). Spacer vibration for fouling control of submerged flat sheet membranes. Separation and Purification Technology, 210, 719-728. doi:10.1016/j.seppur.2018.08.062

Wu, L., Tang, B., Bin, L., Chen, G., Huang, S., Li, P., and Fu, F. (2018). Heterogeneity of the diverse aerobic sludge granules self-cultivated in a membrane bioreactor with enhanced internal circulation. Bioresour Technol, 263, 297-305. doi:10.1016/j.biortech.2018.05.004

Xiao, T., Dou, P., Wang, J., Song, J., Wang, Y., Li, X.-M., and He, T. (2018). Concentrating greywater using hollow fiber thin film composite forward osmosis membranes: Fouling and process optimization. Chemical Engineering Science, 190, 140-148. doi:10.1016/j.ces.2018.06.028

Zhang, Q. H., Yang, W. N., Ngo, H. H., Guo, W. S., Jin, P. K., Dzakpasu, M., Ao, D. (2016). Current status of urban wastewater treatment plants in China. Environ Int, 92-93, 1122. doi:10.1016/j.envint.2016.03.024 
Zhao, Y. X., Li, P., Li, R. H., and Li, X. Y. (2019). Characterization and mitigation of the fouling of flat-sheet ceramic membranes for direct filtration of the coagulated $\begin{array}{llll}\text { domestic wastewater. J. Hazard. } & \text { Mater., } & 121557 .\end{array}$ doi:10.1016/j.jhazmat.2019.121557 


\title{
Appendix
}

\author{
Appendix 1. DMF for wastewater treatment
}

\begin{tabular}{|c|c|c|c|c|c|}
\hline \multirow{2}{*}{$\begin{array}{l}\text { Membrane } \\
\text { process }\end{array}$} & \multirow{2}{*}{$\begin{array}{l}\text { Waste- } \\
\text { water type }\end{array}$} & \multicolumn{2}{|c|}{ Wastewater characteristics } & \multirow{2}{*}{$\begin{array}{l}\text { Membrane } \\
\text { performance }\end{array}$} & \multirow[t]{2}{*}{ Reference } \\
\hline & & Feed & Permeate & & \\
\hline $\begin{array}{l}\text { Lab-scale } \\
\text { operated }\end{array}$ & $\begin{array}{l}\text { Synthetic dye } \\
\text { wastewater }\end{array}$ & $\begin{array}{l}1 \mathrm{~g} / \mathrm{L} \text { dye solution } \\
\text { including Direct red } 80, \\
\text { Disperse blue } 56, \text { Acid } \\
\text { red } 4 \text {, Basic blue } 3\end{array}$ & $\begin{array}{l}\text { Direct red 80: 99- } \\
\text { 100\% removal } \\
\text { Disperse blue 56: 99.4- } \\
\text { 100\% removal } \\
\text { Acid red 4: } 83-96.5 \% \\
\text { removal } \\
\text { Basic blue 3: } 21.2-41 \% \\
\text { removal }\end{array}$ & $\begin{array}{l}\text { Permeability ratio } \\
\text { decreased from } 1 \\
\text { to } 0.6-0.75 \text { within } \\
140 \text { min }\end{array}$ & $\begin{array}{l}\text { (Akbari et al., } \\
\text { 2002) }\end{array}$ \\
\hline $\begin{array}{l}\text { Lab-scale } \mathrm{NF} \\
\text { (Tubular) operated } \\
\text { at a constant } \\
\text { pressure of } 35 \mathrm{bar}\end{array}$ & $\begin{array}{l}\text { Greywater } \\
\text { (from } \\
\text { washing } \\
\text { machine) }\end{array}$ & $\begin{array}{l}\text { Conductivity: } 1080 \pm 73 \\
\mu \text { S/cm } \\
\text { Turbidity: } 120 \pm 17 \mathrm{NTU} \\
\text { TSS: } 78 \pm 18 \mathrm{mg} / \mathrm{L} \\
\text { TOC: } 503 \pm 49 \mathrm{mg} / \mathrm{L} \\
\text { COD: } 1340 \pm 46 \mathrm{mg} / \mathrm{L} \\
\text { Total flora: } 5.7 \pm 1.4 \mathrm{log} \\
\text { E. coli: } 3.3 \pm 0.2 \mathrm{log} \\
\mathrm{Ca}^{2+}: 128 \pm 20 \mathrm{mg} / \mathrm{L} \\
\mathrm{Mg}^{2+}: 32 \pm 5 \mathrm{mg} / \mathrm{L}\end{array}$ & $\begin{array}{l}\text { Conductivity: } 59-329 \\
\mu \mathrm{S} / \mathrm{cm} \\
\text { COD: } 25-134 \mathrm{mg} / \mathrm{L} \\
\text { TOC: } 9-50 \mathrm{mg} / \mathrm{L} \\
\text { Turbidity: ND } \\
\text { TSS: ND } \\
\text { Total flora: ND } \\
\text { E. coli: ND }\end{array}$ & $\begin{array}{l}\text { Flux decreased } \\
\text { from } 90 \text { to } 49 \\
\text { LMH within } 2 \mathrm{~h}\end{array}$ & $\begin{array}{l}\text { (Guilbaud et } \\
\text { al., 2010) }\end{array}$ \\
\hline $\begin{array}{l}\text { Bench-scale MF } \\
\text { (flat sheet) }\end{array}$ & $\begin{array}{l}\text { Municipal } \\
\text { wastewater }\end{array}$ & NA & NA & $\begin{array}{l}\text { Flux achieved at } \\
6.1 \mathrm{LMH}\end{array}$ & $\begin{array}{l}\text { (Hey et al., } \\
2018)\end{array}$ \\
\hline $\begin{array}{l}\text { Lab-scale UF } \\
\text { operated } \quad \text { at a } \\
\text { constant pressure } \\
\text { of } 4 \text { bar }\end{array}$ & $\begin{array}{l}\text { Synthetic dye } \\
\text { wastewater }\end{array}$ & $\begin{array}{l}1 \mathrm{~g} / \mathrm{L} \text { direct red } 80 \text { or } 2 \\
\mathrm{~g} / \mathrm{L} \text { congo red, direct red } \\
23 \text { or reactive blue } 2 \\
\text { Different salt } \\
\text { concentrations }\left(\mathrm{Na}_{2} \mathrm{SO}_{4} /\right. \\
\mathrm{NaCl}): 5,10,20,30,40 \\
\text { and } 60 \mathrm{~g} / \mathrm{L}\end{array}$ & $\begin{array}{l}>98 \% \text { rejection of dyes } \\
<0.5 \% \text { rejection of } \\
\text { salts }\end{array}$ & $\begin{array}{l}\text { Flux decreases } \\
\text { from } 70-100 \text { to } 0- \\
45 \mathrm{LMH} \text { within } \\
275 \mathrm{~min}\end{array}$ & $\begin{array}{l}\text { (Lin et al., } \\
2016)\end{array}$ \\
\hline $\begin{array}{l}\text { MF }(0.1 \mu \mathrm{m}) \\
\text { operated at a } \\
\text { constant pressure } \\
\text { of } 34 \mathrm{kPa}\end{array}$ & $\begin{array}{l}\text { Municipal } \\
\text { wastewater }\end{array}$ & $\begin{array}{l}\text { SS: } 83 \mathrm{mg} / \mathrm{L} \\
\text { Turbidity: } 42 \mathrm{NTU} \\
\text { Color: } 112 \mathrm{mg} / \mathrm{L} \\
\mathrm{NH}_{4}{ }^{+}-\mathrm{N}: 26 \mathrm{mg} / \mathrm{L} \\
\mathrm{PO}_{4}{ }^{3-}-\mathrm{P}: 5.4 \mathrm{mg} / \mathrm{L} \\
\text { BOD: } 102 \mathrm{mg} / \mathrm{L} \\
\text { Bacteria: } 7 \times 10^{7} \text { cells } / \mathrm{mL}\end{array}$ & $\begin{array}{l}\text { SS: } 0 \mathrm{mg} / \mathrm{L} \\
\text { Turbidity: } 1.7 \mathrm{NTU} \\
\text { Color: } 13 \mathrm{mg} / \mathrm{L} \\
\mathrm{NH}_{4}{ }^{+}-\mathrm{N}: 21 \mathrm{mg} / \mathrm{L} \\
\mathrm{PO}_{4}{ }^{3-}-\mathrm{P}: 4.9 \mathrm{mg} / \mathrm{L} \\
\text { BOD: } 10 \mathrm{mg} / \mathrm{L} \\
\text { Bacteria: } \mathrm{ND}\end{array}$ & $\begin{array}{l}\text { Flux decline at } 47- \\
92 \% \text { within } 200 \mathrm{~h}\end{array}$ & $\begin{array}{l}\text { (Kim et al., } \\
2007 \mathrm{a})\end{array}$ \\
\hline $\begin{array}{l}\text { Lab-scale MF } \\
(5,1,0.5 \mu \mathrm{m})\end{array}$ & $\begin{array}{l}\text { Greywater } \\
\text { and } \\
\text { rainwater }\end{array}$ & $\begin{array}{l}\text { Greywater: } \\
\text { Conductivity: } 194 \mu \mathrm{S} / \mathrm{cm} \\
\text { Turbidity: } 12.6 \mathrm{NTU} \\
\text { Color: } 49 \\
\text { COD: } 22.9 \mathrm{mg} / \mathrm{L} \\
\text { Particle count }(2-15 \mu \mathrm{m}) \text { : } \\
22495 \\
\text { Total count: } 60 \mathrm{~mL}^{-1} \\
\text { Total coliform: } \\
\text { MPN/100 mL } \\
\text { Greywater+ Rainwater: } \\
\text { Conductivity: } 181 \mu \mathrm{S} / \mathrm{cm} \\
\text { Turbidity: } 5.9 \mathrm{NTU} \\
\text { Color: } 25 \\
\text { COD: } 12.5 \mathrm{mg} / \mathrm{L} \\
\text { Particle count }(2-15 \mu \mathrm{m}): \\
\text { 17708 } \\
\text { Total count: } 33 \mathrm{~mL}^{-1}\end{array}$ & $\begin{array}{l}\text { Greywater: } \\
\text { Conductivity:163.8- } \\
187.1 \mu \mathrm{S} / \mathrm{cm} \\
\text { Turbidity: } \\
\text { NTU } \\
\text { Color: } 13-25 \\
\text { COD: } 6.8-12.6 \mathrm{mg} / \mathrm{L} \text {, } \\
\\
\text { Greywater+ } \\
\text { Rainwater: } \\
\text { Conductivity:124.2- } \\
\text { 140.6 } \mu \mathrm{S} / \mathrm{cm} \\
\text { Turbidity: } 1.36-2.78 \\
\text { NTU } \\
\text { Color: } 11-14 \\
\text { COD: } 5.4-5.6 \mathrm{mg} / \mathrm{L} \\
\\
\text { Rainwater: } \\
\text { Conductivity: } \quad 82.4- \\
87.0 \mu \mathrm{S} / \mathrm{cm} \\
\end{array}$ & $\begin{array}{l}\text { Permeability } \\
\text { decreased from } \\
220 \text { to } 0 \mathrm{LMH} / \mathrm{kPa} \\
\text { within } 30 \mathrm{~min} \\
\text { (Greywater), from } \\
300 \text { to } 0 \\
\mathrm{LMH} / \mathrm{kPa} \text { within } \\
30 \mathrm{~min} \text { (Greywater } \\
+ \text { rainwater), from } \\
310 \text { to } 240 \\
\mathrm{LMH} / \mathrm{kPa} \\
\text { (rainwater) within } \\
30 \text { min }\end{array}$ & $\begin{array}{l}\text { (Kim et al., } \\
2007 b)\end{array}$ \\
\hline
\end{tabular}




\begin{tabular}{|c|c|c|c|c|c|}
\hline & & $\begin{array}{l}\text { Total coliform: } 0 \\
\text { MPN/100 mL } \\
\text { Rainwater: } \\
\text { Conductivity: } 187.1 \\
\text { mS/cm } \\
\text { Turbidity: } 4.76 \mathrm{NTU} \\
\text { Color: } 24 \\
\text { COD: } 12.6 \mathrm{mg} / \mathrm{L} \\
\text { Particle count }(2-15 \mu \mathrm{m}) \text { : } \\
\text { 2570 coliform:>2419 } \\
\text { Total count: } 49 \mathrm{~mL}-1 \\
\text { Total col } \\
\text { MPN/100 mL }\end{array}$ & $\begin{array}{l}\text { Turbidity: } 0.55-0.98 \\
\text { NTU } \\
\text { Color: } 11-12 \\
\text { COD: } 2.0-2.7 \mathrm{mg} / \mathrm{L}\end{array}$ & & \\
\hline $\begin{array}{l}\text { Lab scale NF } \\
(150-300 \quad \text { Da) } \\
\text { operated at a } \\
\text { constant pressure } \\
\text { of } 800-2400 \mathrm{kPa}\end{array}$ & $\begin{array}{l}\text { Industrial and } \\
\text { synthetic dye } \\
\text { wastewater }\end{array}$ & 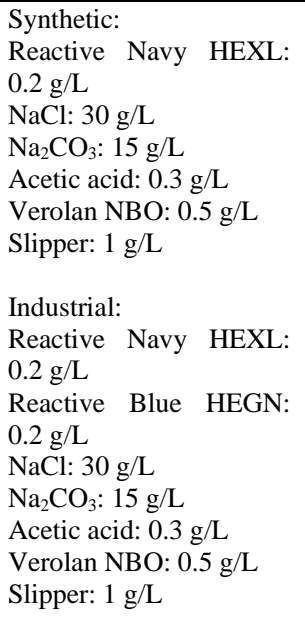 & $\begin{array}{l}\text { Synthetic: } \\
\text { Color removal: }>99 \% \\
\mathrm{Cl}^{-} \text {rejection: } 27-44 \% \\
\text { Industrial: } \\
\mathrm{Cl}^{-} \text {rejection: } 15 \%\end{array}$ & $\begin{array}{l}\text { Synthetic: } \\
\text { Steady state flux at } \\
34-73 \text { LMH } \\
\text { during } \\
2 \mathrm{~h} \\
\text { Industrial: } \\
\text { Flux at } 37.5-47 \\
\text { LMH }\end{array}$ & $\begin{array}{l}\text { (Koyuncu, } \\
\text { 2003) }\end{array}$ \\
\hline $\begin{array}{l}\text { Lab-scale UF } \\
(2.71-3.08 \text { kDa) } \\
\text { operated at a } \\
\text { constant pressure } \\
\text { of } 1-4 \text { bar }\end{array}$ & $\begin{array}{l}\text { Greywater } \\
\text { (Bathroom) }\end{array}$ & $\begin{array}{l}\text { Turbidity: } 70.7-160.3 \\
\text { NTU } \\
\text { TSS: } 101.3-206 \mathrm{mg} / \mathrm{L} \\
\text { COD: } 251-507.5 \mathrm{mg} / \mathrm{L} \\
\text { BOD }_{5}: 81-270.8 \mathrm{mg} / \mathrm{L} \\
\text { E. coli: } 2.5 \times 10^{4}-6.1 \times \\
10^{5} \mathrm{cfu} / 100 \mathrm{~mL} \\
\text { Other coliforms: } 8.5-53.2 \\
\times 10^{4} \text { cfu/100 mL } \\
\text { Pathogenic bacteria: } 5- \\
34.1 \times 10^{5} \mathrm{cfu} / 100 \mathrm{~mL}\end{array}$ & $\begin{array}{l}\text { Turbidity: 94.7-99.9\% } \\
\text { removal } \\
\text { TSS: 100.0-100.0 \% } \\
\text { removal } \\
\text { COD: 60.9-85.5 \% } \\
\text { removal } \\
\text { BOD }: 61.5-86.6 \% \\
\text { removal } \\
\text { E. coli: 100.0-99.9\% } \\
\text { removal } \\
\text { Other coliforms: } 99.8- \\
\text { 100 \% removal } \\
\text { Pathogenic bacteria: } \\
\text { 99-100 \% removal }\end{array}$ & $\begin{array}{l}\text { Flux decreased } \\
\text { from } 135 \text { to } 50 \\
\text { LMH within } \\
28 \mathrm{~h}\end{array}$ & $\begin{array}{l}(\mathrm{Oh} \text { et al., } \\
2016)\end{array}$ \\
\hline $\begin{array}{l}\text { Lab-scale UF } \\
(30,400 \text { and } 200 \\
\text { kDa) operated at a } \\
\text { constant pressure } \\
\text { of } 1-2 \text { bar } \\
\text { Lab-scale NF ( } 200 \\
\text { Da) operated at a } \\
\text { constant pressure } \\
\text { of } 6-10 \text { bar }\end{array}$ & $\begin{array}{l}\text { Greywater } \\
\text { (from public } \\
\text { showers) }\end{array}$ & $\begin{array}{l}\text { TCOD: } 170 \pm 49 \mathrm{mg} / \mathrm{L} \\
\text { Soluble COD: } 106 \pm 42 \\
\text { mg/L } \\
\text { TSS: } 29.8 \pm 11.3 \mathrm{mg} / \mathrm{L} \\
\text { BOD }_{5}: 78 \pm 26 \mathrm{mg} / \mathrm{L} \\
\text { Turbidity: } 23 \pm 8.5 \mathrm{NTU} \\
\text { Conductivity: } 1241 \pm 143 \\
\mu \text { S/cm } \\
\text { TDS: } 599 \pm 43 \mathrm{mg} / \mathrm{L} \\
\text { TOC: } 37.7 \mathrm{mg} / \mathrm{L}\end{array}$ & 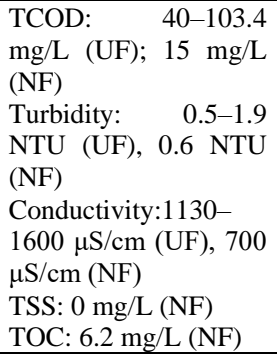 & $\begin{array}{l}\text { NF: } \\
\text { Average steady- } \\
\text { state flux: 15 LMH } \\
\text { ( } 6 \text { bar) / } 35 \text { LMH } \\
\text { (10 bar) }\end{array}$ & $\begin{array}{l}\text { (Ramona et } \\
\text { al., 2004) }\end{array}$ \\
\hline $\begin{array}{l}\text { Lab-scale } \\
\text { operated at a } \\
\text { constant pressure } \\
\text { of } 0.3,0.5 \text { and } 1.0 \\
\text { bar }\end{array}$ & $\begin{array}{l}\text { Municipal } \\
\text { wastewater: } \\
\text { raw and after } \\
\text { primary } \\
\text { clarifier, pre- } \\
\text { filtered (0.56 } \\
\mathrm{mm})\end{array}$ & $\begin{array}{l}\text { Raw sewage: } \\
\text { Conductivity: } \\
\mu S / \mathrm{cm} \\
\text { Turbidity: } 110.02 \mathrm{NTU} \\
\text { TSS: } 63 \mathrm{mg} / \mathrm{L} \\
\mathrm{COD}: 218 \mathrm{mg} / \mathrm{L} \\
\mathrm{TN}: 32.3 \mathrm{mgN} / \mathrm{L} \\
\mathrm{NH}_{4}{ }^{+}: 38.4 \mathrm{mgN} / \mathrm{L} \\
\mathrm{TP}: 5.4 \mathrm{mgP} / \mathrm{L} \\
\mathrm{PO}^{3-}{ }_{4}: 4.1 \mathrm{mgP} / \mathrm{L} \\
\text { Primary effluent: } \\
\text { Conductivity: } \\
\mu \text { S/cm } \\
\text { Turbidity: } 54.62 \mathrm{NTU}\end{array}$ & $\begin{array}{l}\text { Raw sewage: } \\
\text { Conductivity: } 1276 \\
\mu \mathrm{S} / \mathrm{cm} \\
\text { Turbidity: } 0.15 \mathrm{NTU} \\
\text { COD: } 138 \mathrm{mg} / \mathrm{L} \\
\mathrm{TN}: 29.0 \mathrm{mgN} / \mathrm{L} \\
\mathrm{NH}_{4}^{+}: 39.4 \mathrm{mgN} / \mathrm{L} \\
\mathrm{TP:} 4.4 \mathrm{mgP} / \mathrm{L} \\
\mathrm{PO}^{3-}{ }_{4}: 4.0 \mathrm{mgP} / \mathrm{L} \\
\\
\text { Primary effluent: } \\
\text { Conductivity: } \\
\mu \mathrm{S} / \mathrm{cm} \\
\text { Turbidity: } 0.10 \mathrm{NTU} \\
\text { COD: } 78 \mathrm{mg} / 1\end{array}$ & 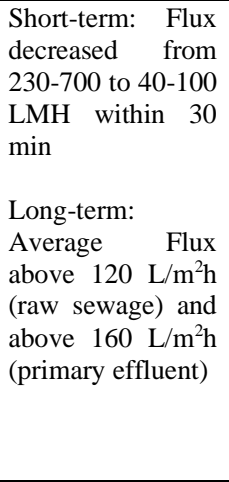 & $\begin{array}{l}\text { (Ravazzini et } \\
\text { al., 2005) }\end{array}$ \\
\hline
\end{tabular}




\begin{tabular}{|c|c|c|c|c|c|}
\hline & & $\begin{array}{l}\text { TSS: } 46 \mathrm{mg} / 1 \\
\text { COD: } 135 \mathrm{mg} / 1 \\
\text { TN: } 32.8 \mathrm{mgN} / \mathrm{L} \\
\mathrm{NH}_{4}{ }^{+}: 29.9 \mathrm{mgN} / \mathrm{L} \\
\text { TP: } 5.0 \mathrm{mgP} / \mathrm{L} \\
\mathrm{PO}^{3-}{ }_{4}: 3.6 \mathrm{mgP} / \mathrm{L}\end{array}$ & $\begin{array}{l}\mathrm{TN}: 28.1 \mathrm{mgN} / \mathrm{L} \\
\mathrm{NH}_{4}{ }^{+}: 30.3 \mathrm{mgN} / \mathrm{L} \\
\mathrm{TP}: 4.1 \mathrm{mgP} / \mathrm{L} \\
\mathrm{PO}^{3-}{ }_{4}: 3.4 \mathrm{mgP} / \mathrm{L}\end{array}$ & & \\
\hline $\begin{array}{l}\text { Pilot-scale } \\
(0.05 \quad \mu F \\
\text { operated at a } \\
\text { constant pressure } \\
\text { of 3-5 bar } \\
\text { Pilot-scale RO } \\
\text { (spiral wound), } \\
\text { operated at a } \\
\text { constant pressure } \\
\text { of 20-30 bar }\end{array}$ & $\begin{array}{l}\text { Greywater } \\
\text { (Hospital } \\
\text { laundry) }\end{array}$ & $\begin{array}{l}\text { TSS: } 35 \mathrm{mg} / \mathrm{L} \\
\text { TN: } 2.75 \mathrm{mg} / \mathrm{L} \\
\text { Ammonia N: } 2.45 \mathrm{mg} / \mathrm{L} \\
\text { TP: } 9.92 \mathrm{mg} / \mathrm{L} \\
\text { COD: } 280 \mathrm{mg} / \mathrm{L} \\
\text { BOD }_{5}: 195 \mathrm{mg} / \mathrm{L} \\
\text { Mineral oil: } 4.8 \mathrm{mg} / \mathrm{L} \\
\text { Anionic surfactant: } 10.06 \\
\text { mg/L } \\
\text { AOX: } 0.12 \mathrm{mg} / \mathrm{L}\end{array}$ & $\begin{array}{l}\text { UF permeate } \\
\text { Temperature: } 53.8^{\circ} \mathrm{C} \\
\text { pH: } 8.3 \\
\text { TSS: } 18 \mathrm{mg} / \mathrm{L} \\
\text { TN: } 0.03 \mathrm{mg} / \mathrm{L} \\
\text { Ammonia N: } 0.03 \\
\text { mg/L } \\
\text { TP: } 0.46 \mathrm{mg} / \mathrm{L} \\
\text { COD: } 130 \mathrm{mg} / \mathrm{L} \\
\text { BOD }: 86 \mathrm{mg} / \mathrm{L} \\
\text { Mineral oil: } 4.4 \mathrm{mg} / \mathrm{L} \\
\text { Anionic surfactant: } \\
7.20 \mathrm{mg} / \mathrm{L} \\
\text { AOX: } 0.11 \mathrm{mg} / \mathrm{L} \\
\text { RO permeate } \\
\text { TSS: } 8 \mathrm{mg} / \mathrm{L} \\
\text { TN: } 0.03 \mathrm{mg} / \mathrm{L} \\
\text { Ammonia } \mathrm{N}: \quad 0.03 \\
\text { mg/L } \\
\text { TP: } 0.14 \mathrm{mg} / \mathrm{L} \\
\text { COD: } 3 \mathrm{mg} / \mathrm{L} \\
\text { BOD }: 1.5 \mathrm{mg} / \mathrm{L} \\
\text { Mineral oil: } 1.2 \mathrm{mg} / \mathrm{L} \\
\text { Anionic } \quad \text { surfactant: } \\
0.91 \mathrm{mg} / \mathrm{L} \\
\text { AOX: } 0.11 \mathrm{mg} / \mathrm{L} \\
\end{array}$ & $\begin{array}{l}\text { UF: Flux stable } \\
\text { between } 110-145 \\
\text { LMH within } 150 \\
\text { min } \\
\text { RO: Flux stable } \\
\text { around } 36 \text { LMH } \\
\text { within } 150 \text { min }\end{array}$ & $\begin{array}{l}\text { (Šostar-Turk } \\
\text { et al., 2005) }\end{array}$ \\
\hline $\begin{array}{l}\text { Pilot-scale NF } \\
(450 \mathrm{Da}) \text { operated } \\
\text { at a constant } \\
\text { pressure of } 0.4-1.4 \\
\mathrm{MPa}\end{array}$ & $\begin{array}{l}\text { Synthetic and } \\
\text { real } \\
\text { fermentation } \\
\text { broth }\end{array}$ & $\begin{array}{l}\text { Fumaric acid: } 2-2.9 \mathrm{~g} / \mathrm{L} \\
\text { Glycerol: } 0-2.5 \mathrm{~g} / \mathrm{L} \\
\text { Succinic acid: } 0-0.05 \mathrm{~g} / \mathrm{L} \\
\text { Citric acid: } 0-0.2 \mathrm{~g} / \mathrm{L} \\
\mathrm{Cl}^{-}: 0-0.32 \mathrm{~g} / \mathrm{L}\end{array}$ & $\begin{array}{l}\text { Fumaric acid: } 2.3-80 \% \\
\text { retention } \\
\text { Glycerol: } \\
\text { retention } \\
\text { Citric acid: } 45 \% \\
\text { retention } \\
\text { Succinic acid: } 80 \% \\
\text { retention } \\
\mathrm{Cl}^{-}: 10 \% \text { retention }\end{array}$ & 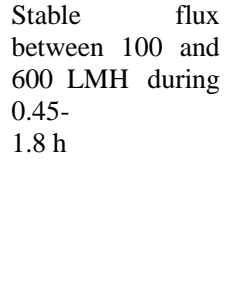 & $\begin{array}{l}\text { (Woźniak and } \\
\text { Prochaska, } \\
\text { 2014) }\end{array}$ \\
\hline $\begin{array}{l}\text { Lab-scale MF } \\
(0.1 \mu \mathrm{m}) \text { operated } \\
\text { at a constant } \\
\text { pressure of } 0.025 \\
\mathrm{MPa} \text {; lab-scale UF } \\
(1000 \text { Da }) \text {, } \\
\text { operated at a } \\
\text { constant pressure } \\
\text { of } 0.5 \mathrm{MPa} \\
\end{array}$ & $\begin{array}{l}\text { Greywater } \\
\text { (from } \\
\text { washing } \\
\text { machine) }\end{array}$ & NA & 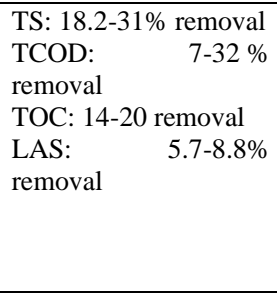 & $\begin{array}{l}\text { Flux decreased } \\
\text { from } 1.5-2 \text { to } 0.3- \\
0.5 \mathrm{LMH} \text { within } \\
\text { about } 4-10 \mathrm{~h}\end{array}$ & $\begin{array}{l}\text { (Zavala et al., } \\
\text { 2014) }\end{array}$ \\
\hline $\begin{array}{l}\text { Lab-scale MF } \\
\text { (Flat sheet, } 100 \\
\text { nm) operated at a } \\
\text { constant flux of } \\
\text { 41.7 LMH }\end{array}$ & $\begin{array}{l}\text { Municipal } \\
\text { wastewater }\end{array}$ & $\begin{array}{l}\text { Turbidity: } \quad 66.7 \pm 15.0 \\
\text { NTU } \\
\text { COD: } 233.0 \pm 30.0 \mathrm{mg} / \mathrm{L} \\
\text { DOC: } 20.2 \pm 1.95 \mathrm{mg} / \mathrm{L} \\
\mathrm{UV}_{254}: 0.185 \pm 0.002 \mathrm{~cm}^{-1} \\
\text { TP: } 4.2 \pm 1.8 \mathrm{mg} / \mathrm{L} \\
\mathrm{PO}_{4}-\mathrm{P}: 1.5 \pm 1.7 \mathrm{mg} / \mathrm{L} \\
\mathrm{NH}_{4}-\mathrm{N}: 24.9 \pm 0.5 \mathrm{mg} / \mathrm{L} \\
\text { pH: } 7.0 \pm 0.1\end{array}$ & $\begin{array}{l}\text { COD: } 24 \mathrm{mg} / \mathrm{L}, 76.4- \\
90 \% \text { removal } \\
\text { TP: } 0.02 \mathrm{mg} / \mathrm{L}, 99.5 \% \\
\text { removal } \\
\text { Turbidity: < } 1.0 \mathrm{NTU}\end{array}$ & $\begin{array}{l}\text { TMP increased } \\
\text { from } 4-8 \text { to } 20 \mathrm{kPa} \\
\text { within } 3 \text { to } 14 \mathrm{~h}\end{array}$ & $\begin{array}{l}\text { (Zhao et al., } \\
2019)\end{array}$ \\
\hline
\end{tabular}

